\title{
Linear Functions and Slope: How Do Students Understand These Concepts and How Does Reasoning Support Their Understanding?
}

\section{Dilek Tanışlı' and Deniz Bike Kalkan² \\ 'Anadolu University, Faculty of Education, Department of Mathematics and Science Education \\ ${ }^{2}$ Ministry of National Education of Turkey}

\section{Abstract}

The aim of this study was to investigate eighth grade students' conceptual understanding and types of reasoning about linear functions and slope. This is a mixed method study. Quantitative data were collected with algebra test, and qualitative data were collected using clinical interviews. The participants for the quantitative part of this study included 103 students, and the qualitative part included 10 students selected from these 103 students who were high and middle achievers. Quantitative data were assessed based on the answer key, and their frequency scores were calculated and interpreted, too. Qualitative data were analyzed using the thematic analysis. The majority of the students counted on superficial knowledge of linear functions and slope, they mainly stuck to the slope formula and line equation, and they did not possess correct reasoning types. They also need to improve their use and interpretation of multiple representations.

Key words: conceptual understanding; mathematics education; middle school students.

\section{Introduction}

What does it mean to learn mathematics? Many theories that explore how people learn have attempted to provide answer to this question. For example, both the constructivist theory and the sociocultural theory emphasize the importance of 
establishing a relationship in the learning process between the new information and the prior knowledge. Measuring the quality and quantity of this relationship between the new information and the prior knowledge highlights the significance of "conceptual understanding". Conceptual understanding is knowledge about the fundamental ideas and connections related to a specific topic (Van de Walle, Karp, \& Bay-Williams, 2012). The "reasoning" strengthens this conceptual knowledge. Reasoning is a mental process that produces new knowledge from the previous knowledge (Rips, 1994). Managing this process effectively leads to deeper understanding of mathematical concepts and keeps students safe from operations and memorized rules. Therefore, we could suggest that conceptual understanding and reasoning are intertwined concepts in learning mathematics (Ball \& Bass, 2003; Kasmer, 2008; Siegler, 2003).

Mathematics is a set of concepts and interrelations among these concepts. Many of these interrelated concepts naturally form a basis for the following concepts. Therefore, not having a proper understanding of a concept can affect the understanding of many other concepts. In this sense, linear functions and slope are key concepts because they are prerequisites for some mathematical concepts and for understanding various ideas related to real life. Linear functions are a subset of linear changing patterns and functions. Linearity, which is presented through linear changing patterns at elementary school, is the focus of middle school mathematics. Linear functions can be described as those whose graph is a straight line or constantly continuous. Analysis of change is one of the four goals of algebra standards (NCTM, 2000). A rate (constant or changing) is a type of change associated with how fast anything moves, and it is a pretty good context to examine linearity. The slope is defined as "a numerical value that represents the rate of change in a linear function" or as "the ratio of the vertical and horizontal changes between two points on a line (geometric ratio)" or "as the tangent value of any angle that a straight line makes with the positive direction of the X-axis (trigonometric conception)" (Stump, 1999; Van de Walle, Karp, \& Bay-Williams, 2012). Association between these various representations along the process promotes deeper understanding of the slope conceptually.

Linear functions and slope are the subdomains of algebra content in middle school mathematics curriculum in Turkey. They are mostly mentioned in the seventh and eighth grades. Seventh grade curriculum has a unit in which students are expected to recognize the coordinate system; to represent the change of one variable in terms of other having a linear relationship using tables, graphs and equations; and to make a sketch of graphs of linear equations. In the eighth grade, units include examining the linear relationship between two variables; finding the slope of a line; and exploring the relationships between linear equations, graphs and tables, paying attention to the meaning of slope (MNE, 2013).

Previous studies showed that students had difficulties in understanding both the linear functions and the slope, and had various misconceptions about these concepts (Barr, 1981; Duncan \& Chick, 2013; Greenes, Chang, \& Ben-Chaim, 2007; 
Planinic, Milin-Sipus, Kati, Susac, \& Ivanjek, 2012; Postelnicu, 2011; Stump, 2001b; Wilhelm \& Confrey, 2003). Furthermore, even teachers have difficulties in establishing connections between different representations of the slope (Stump, 1999). Relevant research is often conducted with high school or university students. The most common challenges are that students do not have conceptual understanding about slope and rate of change, and they have difficulty establishing a relationship between them (Barr, 1981; Crawfort \& Scott, 2000; Greenes et al., 2007; Planinic et al., 2012; Postelnicu, 2011; Stump, 2001b). Barr (1981), for example, pointed to some difficulties in learning the slope:

- confusion with the idea that the slope can be considered as a ratio,

- confusion with the question of "x over $y$ " or " $y$ over $x$ " when finding the slope of a line if given two points,

- confusion of what " $m$ " and "c" refer to in the general equation of a straight line of the form $y=m x+c$, and

- inability to find the slope of a line when given two points.

Research has also identified some serious difficulties such as: considering the slope only as "height" or "angle" (Clement, 1985; Duncan \& Chick, 2013; Stump, 2001b); confusion in measuring height and calculating the rate of change (Teuscher \& Reys, 2010); meanings conveyed by symbols due to tendency towards making operational calculations of the slope and memorizing slope formulas (Barr, 1981; Moschkovich, 1996; Stump, 1999); inability to draw the graph of a line and to interpret it, to estimate the rate of change and the slope based on the graph of a line, and inability to distinguish between the positive and negative slopes (Birgin, 2006; Knuth, 2000; Önür, 2008; Postelnicu, 2011; Reiken, 2008; Teuscher \& Reys, 2010). For example, in a study in which seventh grade students in primary school assessed their ability to solve questions about graphs of linear equations, it was observed that students were constrained to plot graphs of linear equations that intersect axes, to construct value tables, and to show coordinates of a given point in a Cartesian coordinate plane (Tekay \& Doğan, 2015). In addition to this, in another study on understanding the slopes of linear functions of primary eighth grade students, Birgin (2012) determined that the performance of the students in expressing slope in the result of transformation between algebraic and graphical representations is lower than the performance of slope expressions using only algebraic representation. In this study, it has been seen that some students have difficulties with equations, graphs and slopes of linear functions and that they have misconceptions. Also, students cannot relate between the slope of line and the points of the $\mathrm{x}$ and $\mathrm{y}$ axes of the graphs of linear functions. Despite that, considering the importance of the relationship between understanding the rate of change and the slope and reasoning, Cheng (2010) suggested that there was a positive relationship between the slope and proportional reasoning based on students' reasoning about steepness. 
There is a need for research investigating how students at middle school, a period when the linear functions and slope are formally introduced, understand these concepts and make use of their reasoning. This study is based on this particular need. Therefore, the aim of this study was to determine the achievement levels of eighth grade students in the area of linear functions and slope, and investigate their conceptual understanding and types of reasoning. The research questions are given below:

1. What are the achievement levels of eighth grade students on linear functions and slope?

2. What is eighth grade students' conceptual understanding and types of reasoning on linear functions and slope?

By exploring the eighth grade students' conceptual understanding and types of reasoning about linear functions and slope, this study focused on the understanding that middle school students have in making sense of these concepts. In this sense, determining the impact of these difficulties on students' new learning experiences could contribute to the teaching-learning process because linear functions and the slope are key concepts and prerequisites for some mathematical concepts, and students who cannot make sense of them properly have difficulty in making sense of other, subsequent concepts. Observing how students make sense of these concepts could be beneficial for the field of teaching mathematics, particularly algebra. Finally, the results from this study could guide the research to be conducted by mathematics educators.

\section{A Framework for Conceptual Understanding and Reasoning}

Conceptual understanding is the best way of understanding and practicing mathematics, which has an abstract structure. Establishing connections between mathematical concepts, operations and relationships is important in achieving conceptual understanding. Therefore, conceptual understanding requires the ability to use operations, concepts and processes. Hiebert and Lefevre (1986) defined conceptual understanding simply as rich knowledge in relationships. Van de Walle et al. (2012) defined it as knowledge related to the basic ideas about or relationship between a subject or a concept. Conceptual understanding can be considered as an interrelated part of knowledge; if the learner is able to define the relationship to other pieces of knowledge, then this could be considered as conceptual understanding (Skemp, 1987). In conceptual understanding, only recognizing the concept or knowing the definition and the name of the concept is not sufficient, but it is also necessary to see the mutual transitions and relationships between concepts (Soylu \& Aydın, 2006).

The student's own questioning and thinking, that is, his or her reasoning skill, plays a key role in the realization of conceptual understanding. NCTM (2000) described reasoning with stages of making mathematical conjectures and developing and evaluating mathematical arguments, and emphasized the importance of reasoning 
for knowing and understanding mathematics. Blanton and Kaput (2005, p. 413) defined algebraic reasoning, a part of mathematical reasoning, as "a process in which students generalize mathematical ideas from a set of particular instances, establish those generalizations through the discourse of argumentations, and express them in increasingly formal and age appropriate ways". Blanton and Kaput (2005) also argued that algebraic reasoning tasks needed to be embedded in a daily structure of lessons. In general, mathematical reasoning allows students to think critically both together and individually. This process involves guidance on expressing the reasons for what lies at the root of difficult problems and students' creation, and description and justification of new mathematical ideas. There is a widespread consensus among mathematics educators that mathematical reasoning is fundamental for the entire learning experiences (Stylianides \& Silver, 2004).

It is important to recognize that, in learning, conceptual understanding and mathematical reasoning are not mutually exclusive, but they are related. Kasmer (2008) showed that conceptual understanding enhanced reasoning just as well as reasoning enhanced conceptual understanding. Ball and Bass (2003) suggested that mathematical understanding would not be possible without reasoning. Therefore, conceptual understanding and reasoning play a critical role in increasing achievement in learning and teaching mathematics, in minimizing the difficulties of students, and in avoiding misconceptions. In this study, conceptual understanding and reasoning are assumed to be interrelated concepts. Kasmer (2008) introduced a framework to explain the reasoning and conceptual understanding. In this study, some of Kasmer's (2008) indicators of reasoning and conceptual understanding were used in data analysis (see Table 1 and Table 2). At the same time, data were analyzed according to one of the indicators of reasoning $\mathrm{R}(4)$ (see Table 1) which includes inductive, deductive, abductive and proportional reasoning. In this study, deductive reasoning refers to applying the general rule to conclude a specific result; on the other hand, inductive reasoning proceeds from a specific case to drawing conclusion on the general rule.

Table 1

Indicators of reasoning

\begin{tabular}{ll}
\hline & \multicolumn{1}{c}{ Indicators of reasoning } \\
\hline$R(1)$ & Formulate, evaluate, support, and use generalizations. \\
$R(2)$ & Construct, evaluate, and support/dispute mathematical arguments. \\
$R(3)$ & Analyze/evaluate a problem situation. \\
$R(4)$ & Use inductive/deductive reasoning to establish/support mathematical relationships. \\
$R(5)$ & Make sense of different ways of thinking/ideas/approaches and provide rationale \\
& behind them. \\
$R(6)$ & Ask questions and raise challenges in situations of misunderstanding or disagree- \\
$R(7)$ & ment. \\
\hline
\end{tabular}


Table 2

Indicators of conceptual understanding

\begin{tabular}{ll}
\hline & \multicolumn{1}{c}{ Indicators of conceptual understanding } \\
\hline $\mathrm{U}(1)$ & Represent patterns in tables, graphs, words, and equations. \\
$\mathrm{U}(2)$ & Understand and recognize patterns as linear, exponential, etc. \\
$\mathrm{U}(3)$ & $\begin{array}{l}\text { Understand the meaning of a representation (an equation, a table, or a graph) as a } \\
\text { whole and parts of it. }\end{array}$ \\
$\mathrm{U}(4)$ & Understand and use the relationship among a table, an equation, and a graph. \\
$\mathrm{U}(5)$ & $\begin{array}{l}\text { Use equations, graphs, and tables to solve problems and relate the answers to } \\
\text { problem situations. }\end{array}$ \\
$\mathrm{U}(6)$ & $\begin{array}{l}\text { Find a pattern in a table/graph and use the pattern to predict a particular incident. } \\
\mathrm{U}(7)\end{array} \quad \begin{array}{l}\text { Identify and compare characteristics of tables, graphs and equations of linear or } \\
\text { non-linear relationships }\end{array}$ \\
\hline
\end{tabular}

Moreover, abductive reasoning starts with the observation of a surprising case and leads to a new rule which makes these specific cases less surprising (Reid \& Knipping, 2010). The proportional reasoning is defined as identifying the proportional and nonproportional situations (Owens, 1993). Thus, by using these indicators, we could draw conclusions and make a reliable evaluation about the conceptual understanding and reasoning of students about linear functions and slopes.

\section{Methodology}

\section{Research Design}

This study used a mixed method research design, which involves the mixture of qualitative and quantitative data, methods, methodologies, and/or paradigms (Creswell, 1994). The most decisive reason for the use of this research design was to determine students' levels of achievement relating to linear function and slope, primarily with more participants by using the quantitative methods. The purpose of collecting quantitative data was to support the qualitative data rather than making generalizations. Despite that, investigating the conceptual understanding and reasoning of students with different achievement levels about these concepts in depth requires using the qualitative research methods.

\section{Participants}

The participants were selected from eighth grade students in Turkey, who attended a state-funded school, averagely developed in terms of socio-economic level. The participants in the quantitative part of this study included 103 students who were willing to participate in the study, and the participants in the qualitative part included 10 students selected among these students. The participants in the quantitative study were selected using the convenience sampling method (Teddlie \& Yu, 2007). Therefore, the study firstly included eighth grade students who were willing to participate in our research and who were attending two public schools that were easily available and 
had approximately the same socio-economic conditions. For the qualitative part of the study, the participants were selected using the criterion sampling method, which is a purposeful sampling strategy (Yıldırım \& Şimşek, 2005). The pre-determined criterion of importance was that each chosen student had a high or middle achievement level according to his or her ranking score on an open-ended algebra test. This criterion was considered important so as to determine whether there were common or different phenomena among diverse situations.

\section{Data Collection}

The quantitative data were collected with an open-ended algebra test while the qualitative data were collected using the clinical interview (Clement, 2000). The algebra test consisted of a total of 12 questions with subitems. Then a pilot test was administered to 32 eighth grade students. Then, the test was distributed to 103 participants within a class hour in 2 schools which had average socio-economic conditions. In order to measure the reliability of the test, firstly the answer key for each question in the test was prepared and scored. In the scoring process, the maximum score that could be taken from the test was distributed in equilibrium manner according to the degree of importance and difficulty of each problem. The total score assigned to each question was then scored again according to the students' responses (see Appendix), which was directly proportional to the skill of measuring the problem. At the end of the process, the scoring was independently assessed by two field specialists. The relationship between the two evaluations was analyzed by looking at the alpha reliability coefficient and the agreement between the two independent observers. The alpha reliability coefficient was calculated as $\alpha=0.805$. The level of the agreement between the two experts was examined with Kendall's tau coefficient. The Kendall rank correlation coefficient was found to be 0.932 . Thus, the analysis concluded that the majority of the scoring carried out by the two experts was consistent.

Firstly, the clinical interview questions were designed based on the algebra test. Then some alternative and probe questions related to them were prepared. Apart from the items in the algebra test, there are other questions in the clinical interview to investigate the students' conceptual understanding and reasoning about linear relationship, rate of change, equation, and slope and its tables, graphs and interpretations. Finally, a pilot study was conducted with a group of eighth grade students in order to test the prepared clinical interview questions. Clinical interview was conducted with 10 students who were chosen among the students who were high or middle achievers, according to their ranking score on the algebra test. Researchers maintained objectivity in planning and performing the process in all phases of the research. The objective point of view was showed, and the researcher, in the role of an interviewer, interviewed the students. The interviewer asked questions to reveal the students' thinking process without rushing during the interview. 


\section{Data Analysis}

During the analysis of quantitative data, which was the first phase of the research, answer keys for each of the problems in algebra test were prepared and the students' responses were scored according to the target indicators (Table 3).

Table 3

The highest possible scores on the questions in the algebra test

\begin{tabular}{cccc}
\hline Questions & Item Questions & Scores & Total Scores \\
\hline 1 & $1 \mathrm{a}$ & 12 & 26 \\
2 & $1 \mathrm{~b}$ & 14 & 26 \\
& 2 & 26 & \\
& $3 \mathrm{a}$ & 4 & 24 \\
& $3 \mathrm{~b}$ & 4 & \\
& $3 \mathrm{c}$ & 6 & \\
& $3 \mathrm{~d}$ & 10 & 24 \\
& $4 \mathrm{a}$ & 4 & \\
4 & $4 \mathrm{~b}$ & 4 & \\
& $4 \mathrm{c}$ & 4 & \\
& $4 \mathrm{~d}$ & 12 & \\
\end{tabular}

Next, the students' scores were categorized into three groups: high $(\mathrm{H})$ for scores between 77 and 50, middle (M) for scores between 49 and 25, and low (L) for scores between 24 and 0 . Finally, the frequency of the students' overall scores were calculated and interpreted.

Qualitative data were analyzed using the thematic analysis technique (Liamputtong, 2009). In analyzing process, the indicators of conceptual understanding and reasoning which were presented in theoretical framework were considered. The first starting codes were defined by two experts independently. The reliability of coding was calculated and the rate was found to be $90 \%$. After the coding process, the themes and subthemes were determined together with a consensus on them.

As seen in Table 4, the themes Reasoning and Understanding and representing were determined, and under these themes, ten subthemes were constructed. When the results were presented with direct quotes of the participants' responses, relations between the themes and subthemes were discussed under the headings of the graph of a line, the slope of a line, functional relationship and linearity.

Here is one example about the process of identifying codes, themes and subthemes in data analysis. For example, each student's thoughts such as "since points on a line progress according to a constant rate of change, the slope is the same for all the points on the line", "the points on the same line have equal slope angles", "in $y=m x+n$ equations, variables vary, but $m$ does not", and "the slope varies according to the point selected" refer to a code in the examination of how students understand the 
slope of a line. At the same time, students' generalized thoughts about the slope of a line such as "vertical over horizontal" and "tangent of an angle" determined the "generalization" subtheme. Later, two subthemes were classified with the theme of "reasoning". A similar process was carried out for the theme of Understanding and representation. Students' thoughts which are inferred from some premises such as "vertical over horizontal" and "tangent of an angle" are all classified with the theme "deduction reasoning".

Table 4

The themes of 8th grade students' solutions

\begin{tabular}{|c|c|}
\hline $\begin{array}{l}\text { Students' solution } \\
\text { strategies (Themes) }\end{array}$ & Subthemes \\
\hline Reasoning & $\begin{array}{l}\text { Constructing mathematical arguments } \\
\text { Generalization } \\
\text { Evaluating and supporting results } \\
\text { Types of reasoning }\end{array}$ \\
\hline & $\begin{array}{l}\text { Analyzing and solving a problem } \\
\text { Using representations and relating them to problem situations } \\
\text { Understanding the meaning of a representation/concept as a whole } \\
\text { and parts of it }\end{array}$ \\
\hline $\begin{array}{l}\text { Understanding and } \\
\text { representing }\end{array}$ & $\begin{array}{l}\text { Relating between representations } \\
\text { Selecting a particular case in a representation and using it to make a } \\
\text { prediction } \\
\text { Identifying and comparing the properties of the representations that } \\
\text { are compatible or incompatible with the concept }\end{array}$ \\
\hline
\end{tabular}

\section{Results}

\section{Quantitative Results Related to Conceptual Understanding and Reasoning Levels on Linear Functions and the Slope}

Table 5 shows the frequency and percentage distributions of the total scores received by eighth grade students on the algebra test.

Table 5

The frequency and percentage distributions of the students' total scores on the algebra test

\begin{tabular}{ccc}
\hline Scores Range & Frequency & Percentage \\
\hline Low: $0-24$ & 57 & $54.36 \%$ \\
Middle: $25-49$ & 30 & $29.12 \%$ \\
High: $50-77$ & 16 & $15.53 \%$ \\
\hline
\end{tabular}

As can be seen in Table 5, 54.36 \% of the students scored in 0-24 range, $29.12 \%$ scored in 25-49 range, and $15.53 \%$ scored in 50-77 range. These score ranges were then categorized as the low, middle and high achievement levels, respectively. In order to get a more detailed depiction of where the students had difficulty about the concepts, each of the problems and practice questions in the algebra test was evaluated separately. Table 6 shows results of this evaluation. 
In the first problem in the algebra test (Figure 1), the students were asked to represent a real life situation in graphs, express the relationship between the quantities of the graph, and relate the answers to the problem solution and interpret them.

1. Ahmet runs a video game store in a neighborhood. Ahmet charges 3 liras for renting a video game. After a while, Mete also opens a video game store next to Ahmet's and starts to charge 2 liras for renting a video game. After a while, Ahmet's customers begin to rent from Mete. Hoping to attract his customers back, Ahmet plans to make a special offer and decides to charge 1 lira for renting a video game after receiving a 5 -lira advance payment. Taking this last situation into account,

a) Draw the graph of the prices offered by each of the dealers on the same coordinate axis. Please explain how you drew it. U(1), R(3)

b) Which dealer do you think makes a better offer? Explain why. $U(1), U(5), U(6), R(2), R(7)$

Figure 1. Algebra test problem 1

Table 6

Frequency distributions of the total scores on the algebra test

\begin{tabular}{|c|c|c|c|c|c|c|c|c|c|c|c|c|}
\hline \multirow{2}{*}{$\begin{array}{c}\text { Item } \\
\text { Question }\end{array}$} & \multicolumn{2}{|l|}{1} & \multirow[b]{2}{*}{2} & \multicolumn{4}{|c|}{3} & \multicolumn{5}{|c|}{4} \\
\hline & 1 (a) & 1 (b) & & $3(a)$ & $3(b)$ & $3(c)$ & $3(d)$ & $4(a)$ & 4(b) & 4(c) & $\begin{array}{c}4(d) \\
i\end{array}$ & $\begin{array}{c}4(\mathrm{~d}) \\
\mathrm{ii}\end{array}$ \\
\hline Scores & Frequency & $F$ & $\mathrm{~F}$ & $\mathrm{~F}$ & $F$ & $\mathrm{~F}$ & $\mathrm{~F}$ & $\mathrm{~F}$ & $\mathrm{~F}$ & $\mathrm{~F}$ & $\mathrm{~F}$ & $\mathrm{~F}$ \\
\hline 0 & 74 & 46 & 65 & 2 & 45 & 41 & 93 & 48 & 52 & 57 & 77 & 65 \\
\hline 1 & 1 & & & & & & & & & & & \\
\hline 2 & 7 & 22 & & & 4 & & & 6 & 5 & 9 & & \\
\hline 3 & 2 & & & & & 21 & & & & & & 29 \\
\hline 4 & & 8 & & 101 & 54 & & & 49 & 46 & 37 & & \\
\hline 5 & 2 & & 25 & & & & & & & & & \\
\hline 6 & 3 & 25 & & & & 41 & & & & & 26 & 9 \\
\hline 7 & 1 & & & & & & & & & & & \\
\hline 8 & 1 & & 7 & & & & & & & & & \\
\hline 9 & 7 & & & & & & & & & & & \\
\hline 10 & & & & & & & 10 & & & & & \\
\hline 12 & 5 & & & & & & & & & & & \\
\hline 14 & & 2 & & & & & & & & & & \\
\hline 26 & & & 6 & & & & & & & & & \\
\hline
\end{tabular}

As can be seen in Table 6,74 students scored zero points on item (a) of the first problem, while only five students scored 12 full points on the same item. On item (b), 46 students scored zero points while two students scored 14 full points. Out of 103 students, 74 students could not draw the target graphs for the problem situation and 46 students were unable to analyze and evaluate the problem. Considering the importance of students' ability to create and interpret graphs for real life situations in understanding the subsequent concepts in mathematics course, the performance of the students was worrying.

For the second problem (see Figure 2), the students were expected to construct arguments, make assumptions and reach a generalization. 
2. In order to find the slope of a line in the graph, does it matter which two points are selected on the line? Please explain. $U(3), R(1), R(2), R(6)$

Figure 2. Algebra test problem 2

As can be seen in Table 6,65 students scored zero points on the second question while only six students scored 26 full points. This shows that most of the students could not discuss what the slope of a line meant on a graph.

In the third problem (see Figure 3 ) the students were expected to analyze and evaluate a problem situation, make assumptions and reach a generalization, represent a pattern in symbols, graphs, numbers and tables, and switch between representations.

3. Scientists have found that there is a linear relationship between crickets' singing frequency and weather temperature, and established a rule that represented the relationship. When we hear crickets singing in the morning for the first time, the frequency is 40 times per minute. It is 160 times per minute at noon. These values are given in the following table.

a) What is the temperature when the singing frequency is $70,80,90,100, \ldots 150$ per minute in the table below? Please calculate. U(1), U(3), R(3)

b) What is the temperature when the singing frequency is 0 ? Please explain how you reached the solution. $\mathrm{U}(3), \mathrm{U}(5), \mathrm{U}(6), \mathrm{R}(3), \mathrm{R}(4)$

c) How does the temperature increase when the singing frequency increases five times per minute? Please explain how you reached the solution. $U(1), U(3), U(5), U(6), R(3), R(4), R(6)$

d) Using the information given, find the pattern for the singing frequency at any given temperature. Please explain what every number means in the pattern. $U(3), U(4), R(1), R(4), R(7)$

Figure 3. Algebra test problem 3

As can be seen in Table 6, only two students could not answer item (a) of the problem, but the remaining 101 students answered it correctly. In this item, the vast majority of the students solved the problem by taking the constant difference between the temperature data into consideration. Although the criteria on item (a) were again assessed on the items (b) and (c) of the same problem, the number of students who scored zero points on items (b) and (c) increased to 45 and 41 respectively, while the number of students who scored full points decreased to 54 and 41 respectively. According to the students' scores on these three items, the students had difficulty in calculating the rate of change between the quantities based on the table. Apparently, since the students focused solely on the temperature or on the singing frequency in this process, they could not establish the relationship between two quantities that varied depending on each other. In item (d), where the number of correct answers was the lowest, the students were asked to analyze the problem situation by establishing relationships between the representations and reach a generalization. Out of 103, only 10 students were able to generalize the given relationship correctly.

Considering the fact that making generalizations is central to mathematical activities, this result is worrying. The students' preference to find an overall pattern 
by focusing only on a single quantity in the table and taking the constant increase or decrease might have prevented them from reaching the target generalization.

4. For the following three equations write the appropriate numbers in the spaces provided.

a) $y=5 x+10 \cup(4), R(4)$

\begin{tabular}{|c|l|l|l|l|l|l|}
\hline$x$ & & & & & & \\
\hline$y$ & & & & & & \\
\hline
\end{tabular}

b) $y=3 x U(4), R(4)$

\begin{tabular}{|c|l|l|l|l|l|}
\hline $\mathrm{x}$ & & & & & \\
\hline $\mathrm{y}$ & & & & & \\
\hline
\end{tabular}

c) $y=5 x^{2} U(4), R(4)$

\begin{tabular}{|c|l|l|l|l|l|l|}
\hline$x$ & & & & & \\
\hline$y$ & & & & & & \\
\hline
\end{tabular}

d) Refer to the tables and equations.

i. Which relationship is linear and which is not? Why?

ii. How do you decide whether a relationship is linear or not by looking at the data in the tables or equations? Please explain in detail. $U(2), U(7), R(1), R(2), R(4)$

Figure 4. Algebra test problem 4

In items (a), (b), and (c) in the fourth question (Figure 4), the students were expected to establish relationships between representations from among the indicators of conceptual understanding and reasoning, to make interpretations and to make assumptions. Unlike the intended behaviors on these three items, on item (d), the students were expected to construct mathematical arguments, reach generalizations by making assumptions and also question linearity.

As can be seen in Table 6, the students had difficulty in interpreting linearity, constructing arguments based on the assumptions and using generalizations. The ability to make sense of linear relationships and establish relationships between a line and a slope play a critical role in the development of mathematical language. The concept of a linear relationship is fundamental to the concept of function, which has an important place in mathematics. Due to its common use in science subjects, it serves as an interdisciplinary link. In the light of these and the students' performance, we could suggest that they could not attain the target behavioral objectives.

As a result, the majority of the students had low levels of conceptual understanding and reasoning skills on the concepts of linear functions and the slope. Despite that, the students' poor expressions of their ways of thinking in the open-ended algebra test could be one of the reasons for this situation. Also, another reason might be students' high familiarity with multiple choice exams and prevalence of exam-oriented teaching practices at schools in Turkey. Therefore, we decided to make a qualitative evaluation in order to elaborately explore the conceptual understanding and reasoning indicators 
of students to be chosen from different levels of achievement (i.e. five students from the high achievement group and five students from the middle achievement group) regarding the concepts in question.

\section{Qualitative Results Related to Conceptual Understanding and Reasoning Structures on Linear Functions and the Slope}

\section{The Graph of a Line}

The first question in the algebra test required drawing the graph representing the linear relationship about the problem situation and interpreting it. As can be seen in Figure 5, the students displayed various behaviors under the themes of Reasoning and Understanding and representing.

Within the theme Understanding and representing, the students tried to solve the problem by analyzing it. In this process, four students $\left(\mathrm{H}_{2}, \mathrm{H}_{3}, \mathrm{H}_{5}\right.$, and $\left.\mathrm{M}_{2}\right)$ answered the problem correctly, but, of these students, only one student with a high level of achievement $\left(\mathrm{H}_{5}\right)$ solved the problem completely. Other students, who could not answer the problem correctly, failed to show the desired performance especially in the graph drawing and made incomplete drawings.

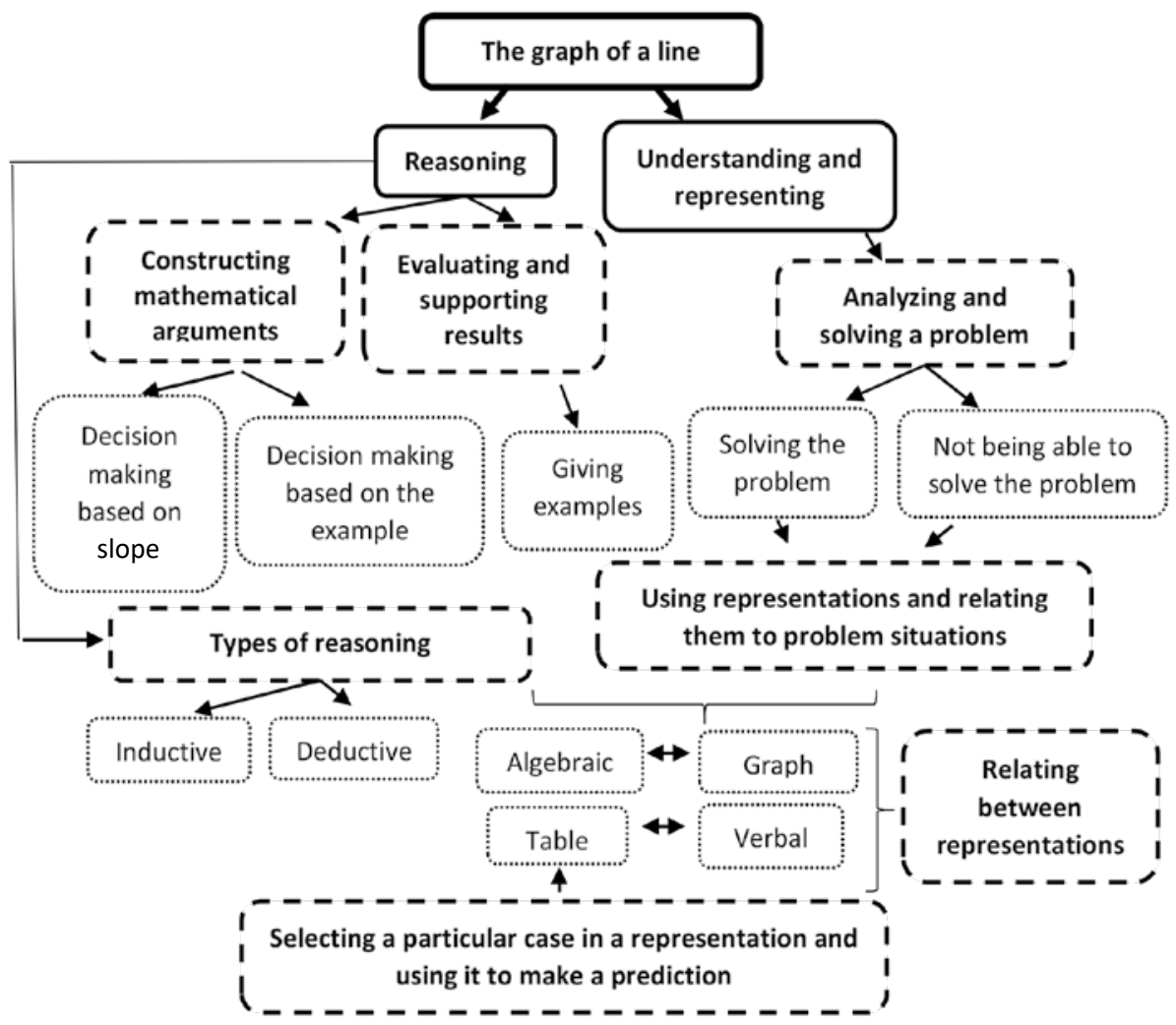

Figure 5. Students' reasoning, understanding and representing of the graph of a line problem 
In the process of solving the problem, four different forms of representation, mainly graph and verbal representation, were used. The use of graphical representation was not very surprising since the problem had already required it. However, what was worrying was that the majority of the students were not able to model the graph of the observed event. While some of the students drew incomplete or incorrect graphs, some of the others could not make any drawing at all. The lack of problem solving skills, and inability to understand a problem in a sense, could be an indication of this situation. Apart from graph and verbal representations, one student $\left(\mathrm{M}_{2}\right)$ used algebraic representation, and two students $\left(\mathrm{H}_{2}\right.$ and $\left.\mathrm{M}_{2}\right)$ used table representation.

Figure 6 shows examples of graphical representations used by some of the students who solved the problem correctly and those who could not solve it.

As can be seen in Figure 6, despite some missing points, we could consider the graphical representation made by student $\mathrm{H}_{5}$ to be correct. However, the measuring units in the axes were not equal because this student did not use a graph paper for graphical representation and the axes were not named, either. Despite that, student $\mathrm{H}_{3}$ modeled the observed situation in the problem with separate graphical representations. The other students either drew incomplete graphs or they could not make any drawings at all.

A common mistake made in graphical representations was the tendency to draw the graph of $y=a$ line, that is, the graph of a line parallel to the axis. The students' tendency to see 2 liras, which Mete charged for each video game in the problem, as "a constant number" might have caused them to think in this way. For instance, the explanation made by student $M_{1}$ is below:

$M_{1}: \ldots$ it asks which dealer offers a better price. This is how I drew the graph. You have to pay Ahmet 5 liras at first, but then you will pay 1 lira for any CD you rent each time no matter how many you rent. That is why I drew it this way.

R: How about Mete?

$M_{1}$ : Mete always charges 2 liras. You will always have to pay 2 liras each time whether you rent 1 or 100 CDs.

Another mistake observed in graphical representation was the tendency to draw the graph of $\mathrm{y}=\mathrm{mx}$ line. Student $\mathrm{M}_{4}$ tried to draw the graph of $\mathrm{y}=\mathrm{mx}$ line instead of drawing that of $y=m x+n$ line. The explanation made by student $M_{4}$ is below:

$\mathrm{M}_{4}$ : Ahmet charges 3 liras for renting video games at first, but when Mete comes, Ahmet offers a deal and starts to charge 1 lira for renting a video game after receiving a 5-lira advance payment. Mete charges 2 liras all the time.

$\mathrm{R}:$ Well, how do you draw Ahmet's graph?

$\mathrm{M}_{4}$ : He receives 5 liras as advance payment at first, but I cannot draw it as a graph. 


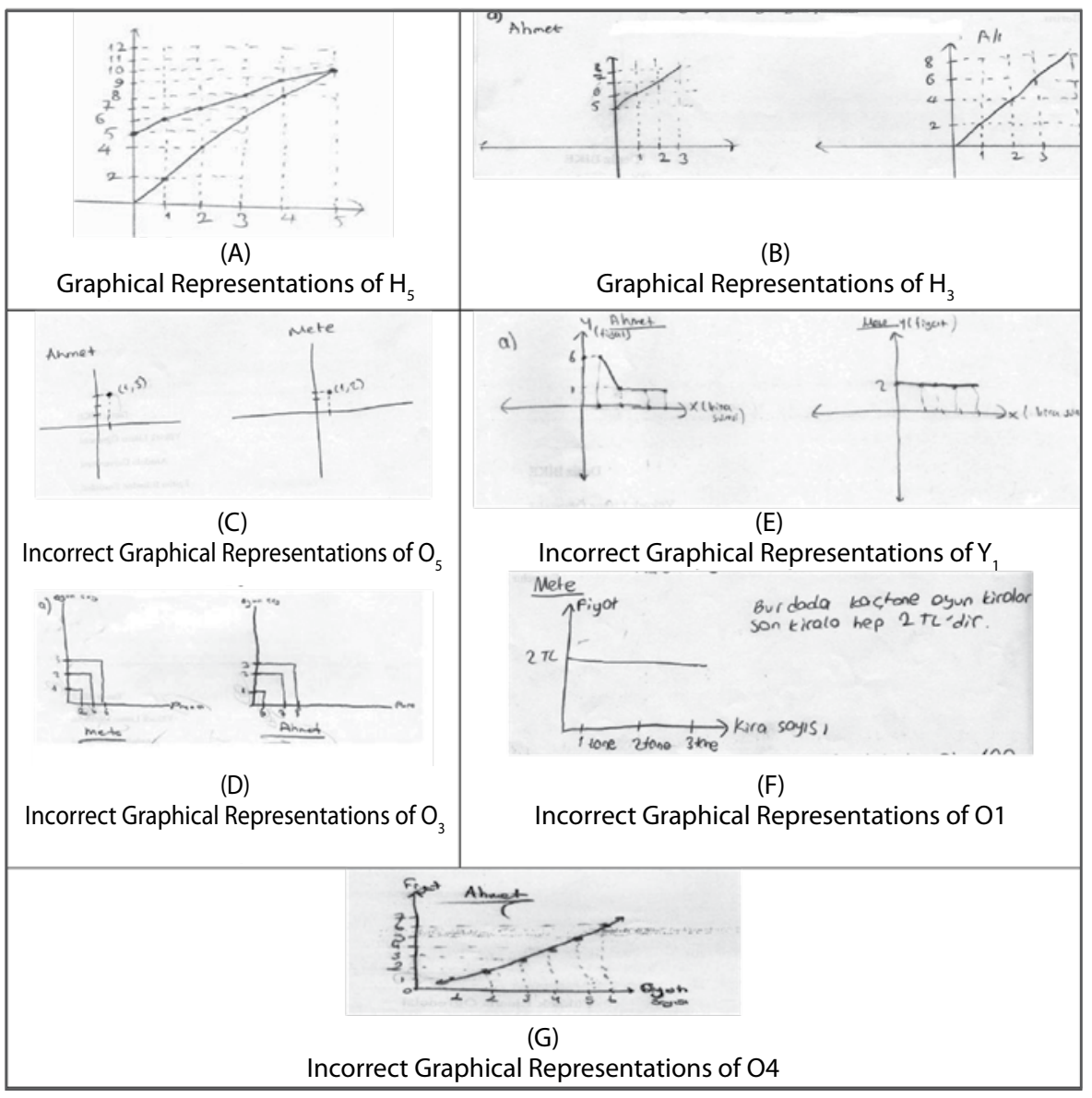

Figure 6. Students' graphical representations

As can be seen in Figure 5, students' reasoning, understanding and representing of the graph of a line also included switching between representations, which is what students $\mathrm{H} 2$ and $\mathrm{M} 2$ did. Student $\mathrm{H}_{2}$ switched from table representation to verbal representation, and student $M_{2}$ switched from algebraic representation to graphical representation, but could not succeed in this exactly. Figure 7 illustrates an example of this situation.
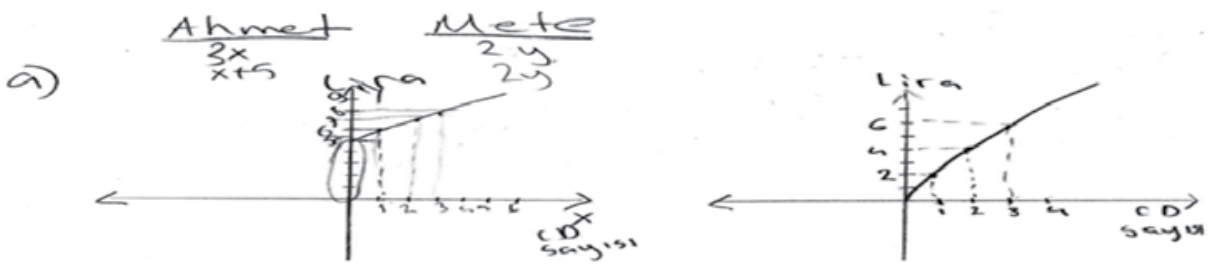

Figure 7. Relating between representations by student $\mathrm{M}_{2}$ for problem 1 
One of the subthemes of Understanding and representing theme was finding a pattern in a representation and using the pattern to make predictions for a particular case. Student $\mathrm{H}_{2}$, for instance, first used table representation to solve the problem, and interpreted the problem by selecting a particular value in the table:

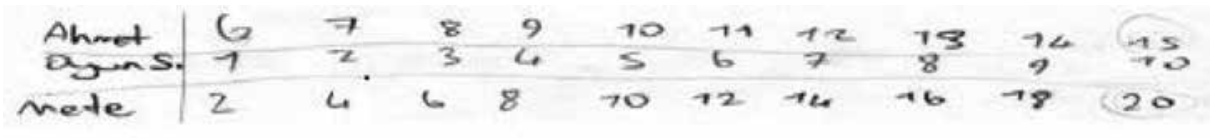

Figure 8. Answer given by student $\mathrm{H}_{2}$ to problem 1

$\mathrm{H}_{2}:$... I made a table, but it is a little bit complicated. I started the first video game directly with the special offer. Ahmet charges 6 liras for it but Mete charges 2 liras. Then, for two games, you pay Ahmet 7 liras, but you pay Mete 4 liras. It goes on like that. It is a better deal to rent from Ahmet when you rent more than five video games. Otherwise, Mete's offer is better. The difference is smaller with more video games. This is because Mete charges 2 liras each time.

$\mathrm{R}$ : OK. What kind of a relationship do you think exists between the data in this table and your graph?

$\mathrm{H}_{2}$ : Well... Um... After a while, you pay Mete more than you pay Ahmet. Ahmet seems more profitable to me.

As can be seen in Figure 5, under the theme of Reasoning, the students constructed a variety of arguments by giving correct or incorrect explanations concerning the problem situation. One of the students with a middle level of achievement $\left(\mathrm{M}_{4}\right)$ made his/her claim about "which dealer offers a better price" based on the slope, other students $\left(\mathrm{H}_{1}, \mathrm{H}_{2}, \mathrm{H}_{3}, \mathrm{H}_{4}, \mathrm{H}_{5}, \mathrm{M}_{1}, \mathrm{M}_{2}, \mathrm{M}_{3}\right.$, and $\left.\mathrm{M}_{5}\right)$ made their claims based on a reference point or, in other words, based on an example they chose. The following, for example, was the explanation made by student $M_{4}$ :

$M_{4:}$ Ahmet is better because of his special offer. This is because Ahmet charges 1 lira for renting each video game once we pay 5 liras at the beginning, but Mete charges 2 liras for renting a video game.

$\mathrm{R}$ : OK. What will you say if I ask you to prove that Ahmet's offer is more profitable? $\mathrm{M}_{4}$ : Well, here is the thing... When we compare the slope for Ahmet's offer and that for Mete's, the slope for Ahmet's offer is 1.I mean the one with the smaller slope is better, right? So, the one with the bigger slope is the highest.

When comparing the offers of the two dealers, student $\mathrm{M}_{4}$ ignored the price change after $\mathrm{x}=6$ value and claimed that Ahmet would offer a better deal at all times. This result could be due to this student's tendency to draw the graph of $y=m x$ line in the graphical representation concerning the problem situation. Despite that, among the other nine students, $\mathrm{H}_{1}$ supported his/her claim by making comparisons on an example he/she had chosen: 
$\mathrm{H}_{1}$ : I think Ahmet's offer is more appealing because suppose that you rent 100 video games; once you pay 5 liras at the beginning and 100 liras for renting 100 video games. However, Mete charges 200 liras for renting 100 video games. The difference is almost $50 \%$.

Similarly, other four students who had constructed correct arguments $\left(\mathrm{H}_{2}, \mathrm{H}_{3}, \mathrm{H}_{5}\right.$, and $\mathrm{M}_{2}$ ) used examples to confirm and support their arguments.

As can be seen in Figure 5, regarding the themes of Reasoning and Understanding and representing, the students, in general, demonstrated an inductive approach by configuring a pattern observed in the problem situation based on a few special cases. However, one of these students $\left(\mathrm{M}_{4}\right)$ also reached a judgment about the better offer based on the slope of the two cases observed in the problem situation and, therefore, demonstrated a deductive approach.

\section{The Slope of a Line}

The second question was about how the students perceived the slope of a line based on a graph, table or equation representation. As can be seen in Figure 9, they made various explanations under the Reasoning theme and the Understanding and representing theme.

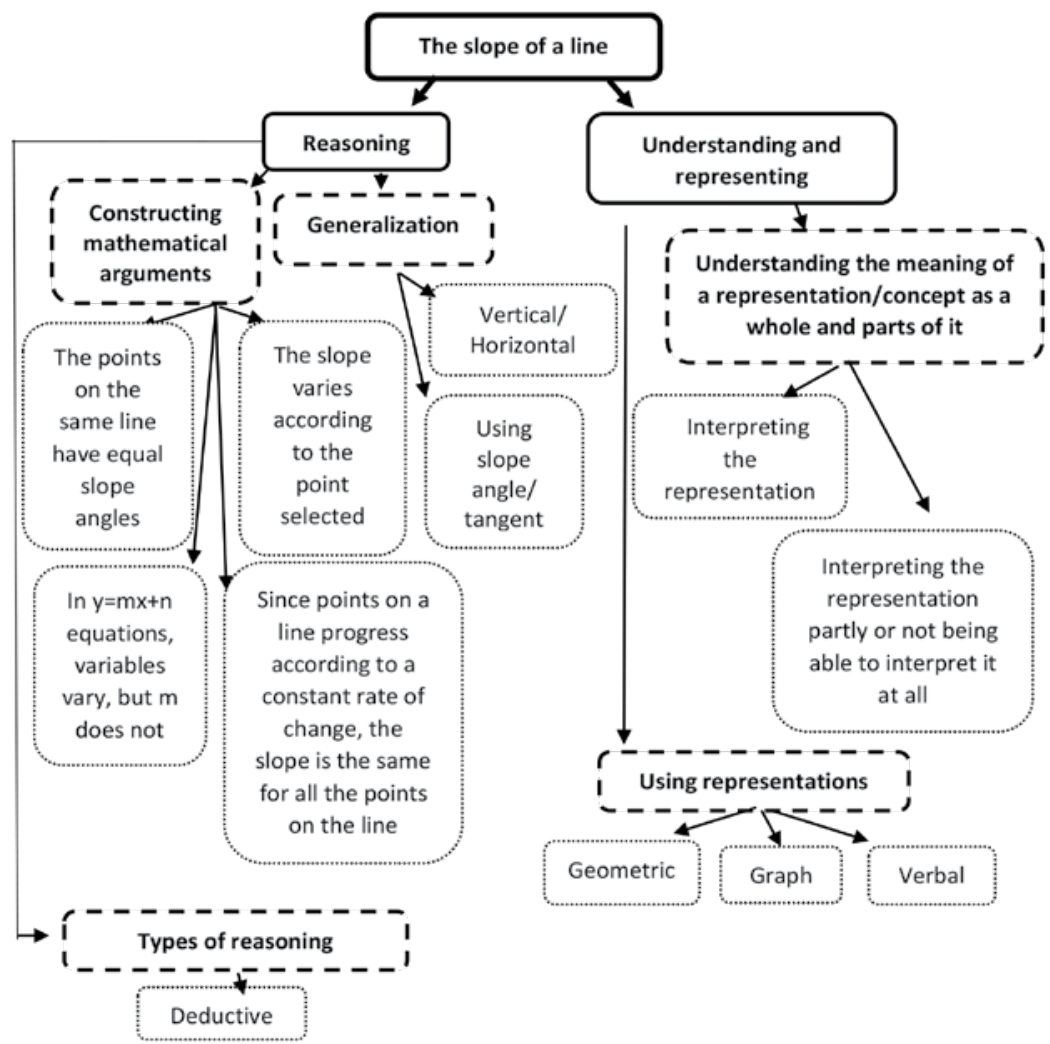

Figure 9. Students' reasoning, understanding and representing of the slope of a line 
While three students with a high level of achievement under the theme of Understanding and representing $\left(\mathrm{H}_{1}, \mathrm{H}_{2}\right.$, and $\left.\mathrm{H}_{4}\right)$ answered this question correctly, the others $\left(H_{3}, H_{5}, M_{1}, M_{2}, M_{3}, M_{4}\right.$, and $\left.M_{5}\right)$ were able to interpret the representation partly or they could not interpret it at all. In this process, the students constructed a variety of formal/informal arguments under the theme Reasoning. As an illustration, three students with a high level of achievement $\left(\mathrm{H}_{1}, \mathrm{H}_{2}\right.$, and $\left.\mathrm{H}_{4}\right)$ explained, "a line progresses according to a constant rate of change, so the slope is the same for all the points on the line". However, student $\mathrm{H}_{2}$ added, "the slope angles of the points on the same line are equal" and demonstrated this statement with a graphical representation. The following was the detailed explanation made by student $\mathrm{H}_{2}$.

$\mathrm{R}$ : What do you think about the second question?

$\mathrm{H}_{2}$ : I think it does not matter because a line is composed of points. If points accumulate, they make up a line. All of these points are on the same line. Selecting this or that (showing points) among these would be the same. This is because they have the same angles with each other.

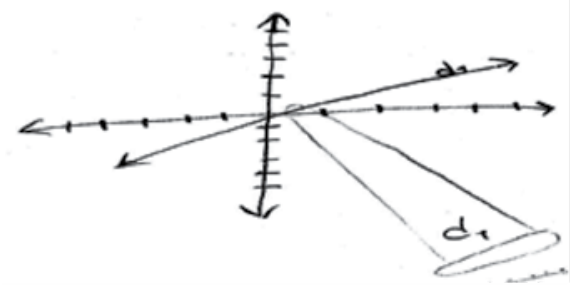

Figure 10. Answer given by student $\mathrm{H}_{2}$ for problem 2

Also, $\mathrm{H}_{1}$ explained, "In $\mathrm{y}=\mathrm{mx}+\mathrm{n}$ equations, variables ( $\mathrm{x}$ and $\mathrm{y}$ ) vary depending on each other, but $\mathrm{m}$ does not". These three students represented the slope with functional properties, parameter coefficients and trigonometric ratios. Despite that, the students who interpreted the given representation partially $\left(\mathrm{H}_{3}, \mathrm{H}_{5}\right.$, and $\left.\mathrm{M}_{4}\right)$ or failed to interpret it $\left(M_{1}, M_{2}, M_{3}\right.$, and $\left.M_{5}\right)$ constructed the argument that "a slope varies according to the point selected on a line".

For example, student $\mathrm{M}_{4}$ made the following explanation using the geometric representation of the slope based on the idea that "the distances of the points where a line intercepts the axis to the origin affect the slope":

$\mathrm{M}_{4}$ : Yes, it does because knowing the distances of $\mathrm{x}$ and $\mathrm{y}$ to the origin affects the answer, since the slope is vertical/horizontal.

Also, student $\mathrm{M}_{3}$ provided another explanation:

$\mathrm{M}_{3}$ : In order for the slope to be calculated, two points should be selected on $\mathrm{x}$ and $y$ axes. Otherwise, there will be no slope.

$\mathrm{R}:$ Why?

$\mathrm{M}_{3}$ : Because it must be 90 degrees. There will not be a slope if it does not have 90 degrees. It must make a right triangle like this (he/she draws it). 
Student $\mathrm{M}_{3}$ claimed that a slope is only possible with a right triangle model formed through a geometric representation based on the points where the line intercepts the axis. In short, neither of the two students were aware of the constancy of the slope on any given point on a line and the equality of the constant rate between the vertical and horizontal lengths. They were also misguided by the idea that "different lines would occur as points varied on the axis and so will change the slope of the lines". Another student with the same idea was student $\mathrm{H}_{3}$. This student also argued that a slope would change parallel to the change of an angle by saying, "Yes, it does. It matters because the slope angle and direction would change according to the points selected". Moreover, these students ignored the lines parallel to the axis as well. Student $M_{5}$ thought the slope formula could be calculated with the points to be taken on the axis and made the following explanation:

$\mathrm{M}_{5}$ : In order to find the slope of a line, numbers marked on $\mathrm{x}$ and $\mathrm{y}$ are taken because this is how the slope formula is found.

As can be seen in Figure 9, the students made generalizations about the slope using geometric representations $\left(\mathrm{H}_{1}, \mathrm{H}_{2}, \mathrm{H}_{3}, \mathrm{H}_{4}, \mathrm{H}_{5}, \mathrm{M}_{1}, \mathrm{M}_{2}, \mathrm{M}_{3}, \mathrm{M}_{4}\right.$, and $\left.\mathrm{M}_{5}\right)$ and trigonometric representations $\left(\mathrm{H}_{2}, \mathrm{H}_{3}\right.$, and $\left.\mathrm{M}_{3}\right)$. In other words, they used a deductive approach by making some inferences for the result based on some premises about the slope throughout the process, such as vertical/horizontal or the tangent of a right triangle and an angle.

\section{Functional Relationship}

The third problem questioned the students' ability to explore the relationship between two quantities - one dependent quantity and one independent quantity - on a linear function and to analyze the rate of change. Figure 11 shows various statements made by the students under the themes of Reasoning and Understanding and representing. Under the theme of Understanding and representing, the students tried to analyze and solve the problem. Only two students with a high and middle level of achievement $\left(\mathrm{H}_{3}\right.$ and $\left.\mathrm{M}_{1}\right)$ were able to solve the problem while the other students could not answer certain items of the problem.

In the first item of the problem, all students calculated the target temperatures by continuing the constant increase in the pattern on the table, and verbally expressed how the temperature would continue. An example of this was the answer given by student $\mathrm{H}_{5}$ (Figure 12). 


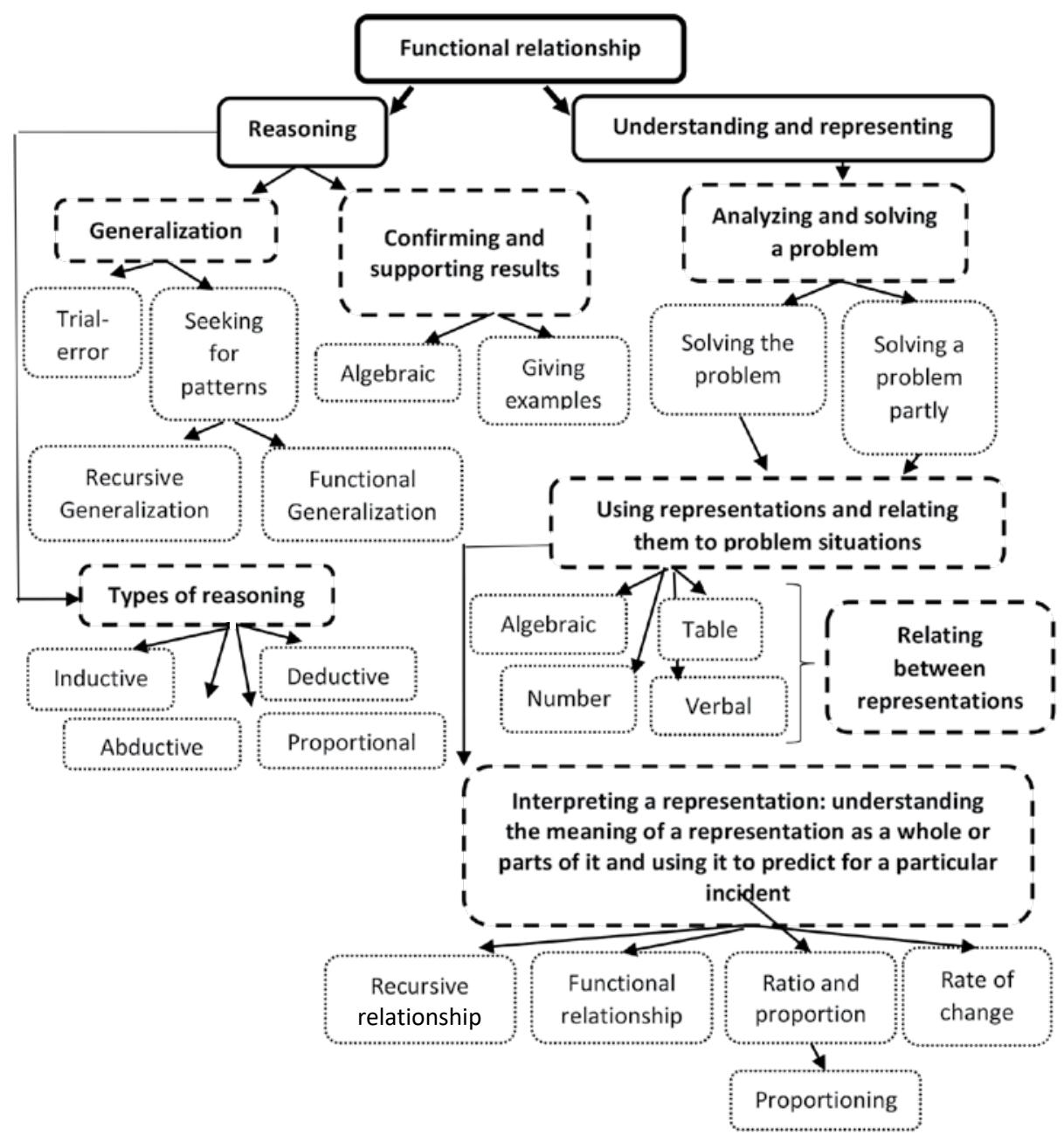

Figure 11. Students' reasoning and understanding and representing of the functional relationship problem

\begin{tabular}{|l|l|l|l|l|l|l|l|l|l|l|l|l|l|}
\hline Sicaklık & 10 & 12 & 14 & 16 & 18 & 20 & 22 & 24 & 26 & 28 & 30 & 32 & 34 \\
\hline $\begin{array}{l}\text { Ötme } \\
\text { sayısı }\end{array}$ & 40 & 50 & 60 & 70 & 80 & 90 & 100 & 110 & 120 & 130 & 140 & 150 & 160 \\
\hline
\end{tabular}

Figure 12. Answer given by student $\mathrm{H}_{5}$ to problem 3(a)

When solving the other items of the problem, the students used three different types of representation apart from verbal representation. Among these students, two students with a high level of achievement and another with a middle level of achievement $\left(\mathrm{H}_{1}\right.$, $\mathrm{H}_{3}$, and $\left.\mathrm{M}_{1}\right)$ used algebraic representation, two students $\left(\mathrm{M}_{1}\right.$ and $\left.\mathrm{H}_{5}\right)$ used numerical representation, and two students $\left(\mathrm{M}_{2}\right.$ and $\left.\mathrm{H}_{5}\right)$ used table representation. Figure 13 shows the examples of representation types used by these students: 


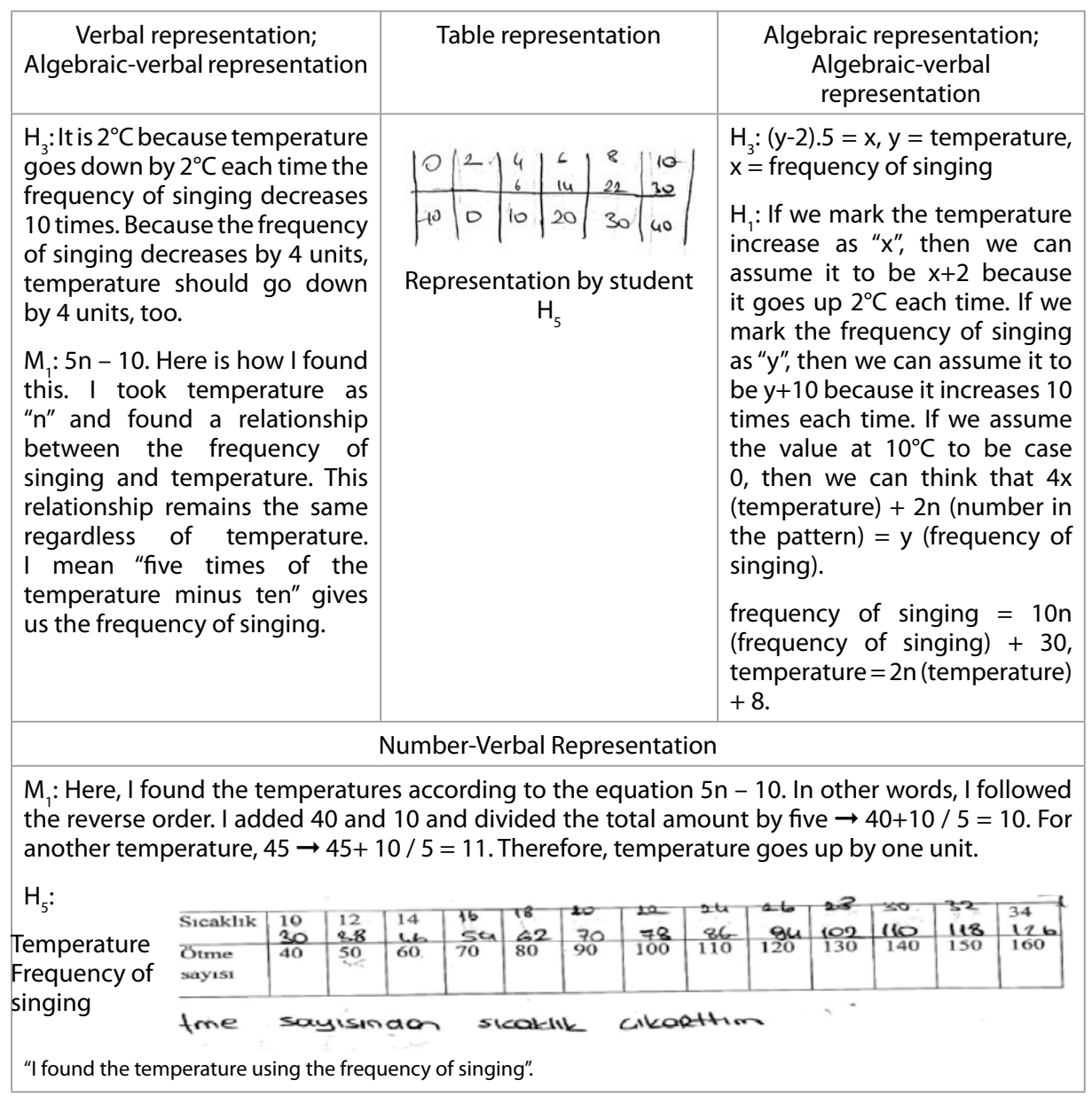

Figure 13. Multiple representations provided by the students for problem 3

When analyzing and solving the problem, the students discovered recursive and functional relationships, and they used ratio-proportion, too.

For the question asking for the temperature when the frequency of singing was 0 , seven students $\left(\mathrm{H}_{1}, \mathrm{H}_{2}, \mathrm{H}_{5}, \mathrm{M}_{2}, \mathrm{M}_{3} \mathrm{M}_{4}\right.$, and $\left.\mathrm{M}_{5}\right)$ calculated the temperature by using the recursive relationship without taking the relationship between the temperature and the frequency of singing into consideration, and based on the constant decrease between the terms in the patterns. An example of this was the answer given by student $\mathrm{M}_{2}$ :

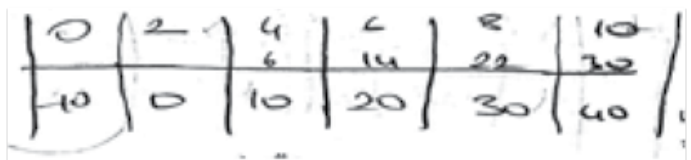

Figure 14. Answer given by student $\mathrm{M}_{2}$ to problem $3(\mathrm{~b})$ 
$\mathrm{M}_{2}$ : Because the minimum temperature for singing is $4^{\circ} \mathrm{C}$ and it starts after $2^{\circ} \mathrm{C}$, crickets never sing at $0^{\circ} \mathrm{C}$ or $2^{\circ} \mathrm{C}$.

Despite that, student $\mathrm{H}_{3}$ reached the temperature value by calculating the extent of the change in the temperature by a constant increase or decrease in the frequency of singing in the table. The following was the explanation made by student $\mathrm{H}_{3}$ :

b) What is the temperature when the singing frequency is 0 ? Please explain how you reached the solution.

$\mathrm{H}_{3}$ : It is $2^{\circ} \mathrm{C}$ because the temperature goes down by $2^{\circ} \mathrm{C}$ each time the frequency of singing decreases by 10 . Since the frequency of singing decreases by four units, the temperature should go down by four units as well.

Although the student did not calculate the rate of change, his/her awareness of the existing change was important conceptually. As can be seen below, the student with a middle level of achievement who reached the solution with a functional approach $\left(M_{1}\right)$ calculated the temperature value by using the equation he/she first established based on the functional relationship between the frequency of singing and temperature.

b) What is the temperature when the singing frequency is 0 ? Please explain how you reached the solution.

$M_{1}$ : Because the equation is $5 n-10 \ldots$ and we mark the temperature as " $n$ ". Therefore, it gives the frequency of singing and we follow the reverse order. I mean if we add 10 and divide the resulting total by 5 , then we find the temperature. $0+10$ $=1010 / 5=2$. The temperature is 2 centigrade degrees.

Similarly, in the next item of the problem that asked how the temperature would increase when the singing frequency increases five times per minute, eight students $\left(\mathrm{H}_{1}, \mathrm{H}_{2}, \mathrm{H}_{3}, \mathrm{H}_{5}, \mathrm{M}_{2}, \mathrm{M}_{3}, \mathrm{M}_{4}\right.$, and $\left.\mathrm{M}_{5}\right)$ estimated the change in the temperature correctly, based on the idea that a decrease in the frequency of singing would be caused by a proportional decrease in temperature. One of these answers is presented below:

c) How does the temperature increase when the singing frequency increases five times per minute? Please explain how you reached the solution.

$\mathrm{M}_{3}$ : In this case, it goes up by 1 centigrade degree each time because it was increasing by two degrees each time. Here, the frequency of singing decreased by half. Then the increase in the temperature will come down by half.

Student $\mathrm{H}_{1}$ calculated the temperature value by proportioning, in the following way:

c) How does the temperature increase when the singing frequency increases five times per minute? Please explain how you reached the solution.

$\mathrm{H}_{1}$ : When the singing frequency increases by 5 , the temperature goes up by $1^{\circ} \mathrm{C}$. I found it with ratio. When the singing frequency increases by 10 , the temperature goes up by $2^{\circ} \mathrm{C}$. In this case, it increases by 5 each time it increases by $1^{\circ} \mathrm{C}$.

Student $M_{1}$, who calculated the temperature value using the equation he/she had formulated, provided the explanation below. Algebraic reasoning involves performing 
mathematical processes and reverting them. In other words, it requires the ability to begin from the starting point and proceed forward, or it requires thinking the other way around and proceeding backwards. This student had an improved conceptual understanding about this problem and, based on his/her behaviors for both items of the problem, we could suggest that he/she had a higher level of algebraic reasoning skills.

c) How does the temperature increase when the singing frequency increases five times per minute? Please explain how you reached the solution.

$M_{1}$ : Here, I found the temperatures according to the equation $5 n-10$. In other words, I followed the reverse order. I added 40 and 10 and divided the total amount by five $\rightarrow 40+10 / 5=10$. For another temperature, it was: $45 \rightarrow 45+10 / 5=11$. Therefore, the temperature goes up by one unit.

One of the subthemes of Understanding and representing theme was switching between representations. As can be seen in Figure 13 or direct quotes from the students' answers, three students $\left(H_{1}, M_{1}\right.$, and $\left.M_{2}\right)$ were able to use combinations of representations as algebraic-verbal, number-verbal, table-verbal representations. However, only one of these students $\left(M_{1}\right)$ was able to relate representations to each other meaningfully.

As can be seen in Figure 11, under the Reasoning theme, some of the students made generalizations about the problem situation, and they tried to confirm and support their generalizations. In terms of generalization, in the last item of the problem, the students were asked to formulate an equation based on the two quantities and to interpret what each term in the equation meant. Unfortunately, only two students $\left(\mathrm{H}_{3}\right.$ and $M_{1}$ ) were able to reach the correct equation. However, one of these two students, student $\mathrm{H}_{3}$ (the one with a high level of achievement), reached the equation through trial-error method and provided the following explanation:

$\mathrm{R}$ : What is the general rule of the pattern?

$\mathrm{H}_{3}$ : $(\mathrm{y}-2) .5=\mathrm{x}$; here $\mathrm{y}$ refers to the temperature and $\mathrm{x}$ refers to the frequency of singing.

R: OK. How did you find that?

$\mathrm{H}_{3}$ : By trying numbers. I tried the numbers in the table.

Student $\mathrm{H}_{3}$ evaluated the accuracy of his/her equation by testing it at a certain temperature. The explanation made by this student is below:

R: So, do these rules apply to all?

$\mathrm{M}_{2}$ : Let us check it. If the temperature is 10 degrees, then $(10-2) \cdot 5=8 \cdot 5=40$ and this is the correct result. The frequency of singing is 40 .

R: How about the next step?

$\mathrm{M}_{2}$ : When the temperature is 12 degrees $(12-2) \cdot 5=50$. This is correct again, and that must be the rule. 
Student $\mathrm{M}_{1}$ constructed the equation based on the functional relationship between the frequency of singing and temperature. This student confirmed the accuracy of the equation with a deductive approach in the following way:

M1: There is a relation between temperature and the singing frequency. In order to find this relation, for example, we should find the same equation between 10 and 40 and 34 and 160 . In these equations, the formula is " 5 n- 10 ". If we give a name " $n$ " for the temperature and use " $5 n-10$ " equation, we can find the singing frequency... $5 n-10$. Here is how I found this. I took temperature as " $n$ " and found a relationship between the frequency of singing and temperature. This relationship remains the same regardless of the temperature. I think "five times of the temperature minus ten" gives us the frequency of singing.

All the students but student $M_{1}$ generally followed an inductive approach in solving the problem. Especially for items (b) and (c) of the problem, some students $\left(\mathrm{H}_{1}, \mathrm{H}_{2}, \mathrm{H}_{3}\right.$, $\mathrm{H}_{5}, \mathrm{M}_{2}, \mathrm{M}_{3}, \mathrm{M}_{4}$ and $\mathrm{M}_{5}$ ) used proportional reasoning by comparing the two quantities and stating how a change in either of them would affect the other. For example, student $\mathrm{H}_{2}$ came up with the following proportional reasoning:

c) How does the temperature increase when the singing frequency increases five times per minute? Please explain how you reached the solution.

$\mathrm{H}_{2}$ : If the singing frequency increases by 10 , the temperature will increase by 2 and if the singing frequency increases by 5 , the temperature will increase by 1 . This is the right proportion.

Student $\mathrm{H}_{1}$ formulated an equation by initially observing a particular incident or, in other words, by taking the constant increase in temperature and the frequency of singing into account with an abductive approach (abductive reasoning is possible when an inference leading to the formation of a claim based on observation of a particular situation emerges). An example of this situation was the following:

$\mathrm{H}_{1}$ : If we give a name " $\mathrm{x}$ " for the temperature, we can say " $\mathrm{x}+2$ " because of an increase by $2^{\circ} \mathrm{C}$ each time. If we give a name " $y$ " for the singing frequency, each time it will go up 10 times and it will be $y+10 \ldots$ If we accept it as a $0^{\text {th }}$ value at $10^{\circ} \mathrm{C}$, it will be $4 x+2 n=y$. The singing frequency $=10 n+30$. The temperature $=2 n+8$.

\section{Linearity}

The fourth problem questioned how linearity was perceived through tables, equations or graphical representations. Figure 15 shows the explanations made by the students under the Reasoning theme and the Understanding and representing theme.

As can be seen in Figure 15, all the students correctly completed the tables given about linear and nonlinear equations under the theme of Understanding and representing. Some of the students, however, used only positive integer values instead of $\mathrm{x}$ in the equations given while some others included number zero among these values. The answer given by one of the students was given below as an example (Figure 16). 


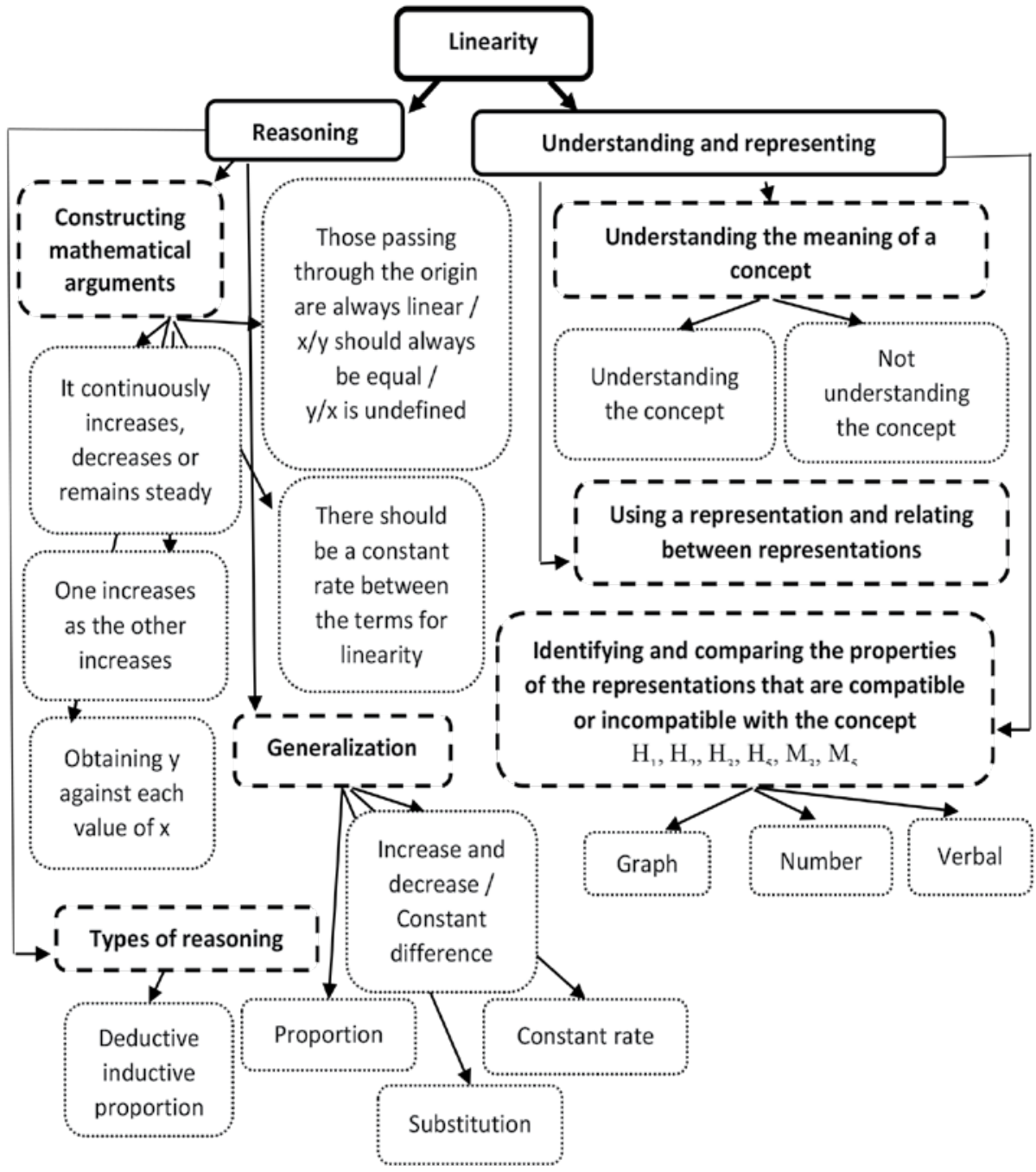

Figure 15. Students' reasoning and understanding and representing linearity

a) $y=5 x+10$

\begin{tabular}{|c|c|c|c|c|c|c|}
\hline $\mathbf{X}$ & 2 & 2 & 3 & 4 & 5 & 6 \\
\hline $\mathbf{X}$ & 15 & 20 & 25 & 30 & 05 & 40 \\
\hline
\end{tabular}

$\cdots$

b) $y=3 x$

\begin{tabular}{|c|c|c|c|c|c|c|}
\hline $\mathbf{X}$ & 1 & 2 & 3 & 4 & 3 & 6 \\
\hline $\mathbf{Y}$ & 3 & 6 & 9 & $1 / 2$ & 15 & 18 \\
\hline
\end{tabular}

c) $y=5 x^{2}$

\begin{tabular}{|l|l|l|l|l|l|l|}
\hline $\mathbf{x}$ & 1 & 2 & 3 & 4 & 5 & 6 \\
\hline $\mathrm{x}$ & 5 & 20 & 45 & 80 & 125 & 180 \\
\hline
\end{tabular}

Figure 16. Answer given by student $M_{4}$ to problem $4(a, b, c)$ 
The fourth problem questioned the concept of linearity. For item (d) of this problem, four students with a high level of achievement $\left(\mathrm{H}_{1}, \mathrm{H}_{2}, \mathrm{H}_{3}\right.$, and $\left.\mathrm{H}_{5}\right)$ and two students with a middle level of achievement $\left(\mathrm{M}_{3}\right.$ and $\left.\mathrm{M}_{5}\right)$ interpreted the linear relationship by examining their equations and table representations. These students expressed the linear relationship with a continuous increase or decrease in $\mathrm{x}$ and $\mathrm{y}$ values whereas only one student $\left(\mathrm{H}_{1}\right)$ stated the constant line in addition to that. Those students took the constant difference in $y$ values in particular while some other students $\left(\mathrm{H}_{1}, \mathrm{H}_{3}\right.$ and $M_{3}$ ) emphasized the rate of change to some extent. Samples from the students' thoughts about the concept of linearity can be seen below:

d) Which relation is linear and which is not? Why?

$\mathrm{H}_{1}$ : Linear $=$ is what we can describe as a constant progress. In linear relations, it goes up with constant or stays constant or decreases permanently. Sometimes, there is a ratio. For example, the graph which shows the effect of temperature on the singing frequency is linear and goes up permanently.

$\mathrm{H}_{3}: \quad$ I thought items (a) and (b) were linear.

$\mathrm{R}: \quad$ Why did you think so?

$\mathrm{H}_{3}$ : Here, $\mathrm{x}$ increases in parallel to $\mathrm{y}$. In $\mathrm{y}=3 \mathrm{x}$ equation, $\mathrm{x}$ increases in parallel to y.

$\mathrm{R}: \quad$ But $\mathrm{x}$ value goes up as $\mathrm{y}$ value goes up in item (c), too?

$\mathrm{H}_{3}$ : Yes, it does, but I could not find any specific rule there.

$\mathrm{R}: \quad$ How did you find the others then?

$\mathrm{H}_{3}$ : In item (a), y increases by five, and it increases by three in item (b).

$\mathrm{R}: \quad$ What about item $(\mathrm{c})$ ?

$\mathrm{H}_{3}$ : I could not see a constant rate there, so I thought that was not linear.

$\cdots$

R: Why do you think $y=5 x^{2}$ did not increase at a certain rate?

$\mathrm{H}_{3:} \quad$ Because item (c) is a quadratic equation. I mean it has square. Things change in this case. It does not rise at a constant rate.

d) Which relation is linear and which is not? Why?

$\mathrm{M}_{3}: \mathrm{a}$ and $\mathrm{b}$ are linear because they increase and decrease with the same ratio. However, $c$ is not like that.

$\mathrm{R}$ : What do you mean by saying it increases and decreases in the same way?

$M_{3}$ : It goes by five in item (a) and by three in item (b). That is why I said it increases and decreases in the same way.

Student $\mathrm{H}_{5}$ compared and contrasted representations by switching from algebraic representation to table representation, and from table representation to graph, numerical and verbal representations. Also, this student expressed linearity with a flat line on the graph.

d) Which relation is linear and which is not? Why? 


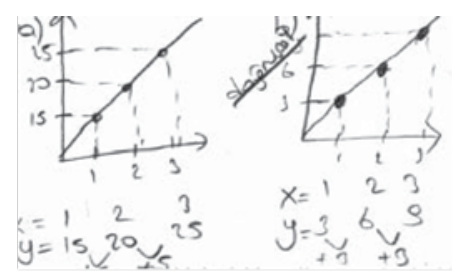

Figure 17. Relating between representations by student $\mathrm{H}_{5}$ for problem 4(d)

R: For the given equations, how do you decide which ones have a linear relationship?

$\mathrm{H}_{5}$ : I drew their graphs first (pointing to the graph he/she drew). When I assigned 1,2 and 3 to $x, y$ constantly became 15,20 and 25 , respectively. I thought there must be a linear relationship there because it increased by 5 each time and the graph proceeded steadily.

$\mathrm{R}: \mathrm{OK}$. Do the others have a linear relationship, too?

$\mathrm{H}_{5}$ : Item (b) has it, but item (c) does not.

$\mathrm{R}:$ Why is that so?

$\mathrm{H}_{5}$ : Because when I assigned values, y turned out to be 5,20 and 45. There was no pattern here. If I drew its graph, it would not be linear.

R: So, how do you decide whether there is a linear relationship or not by looking at a chart?

$\mathrm{H}_{1}$ : If it is nonlinear, there will not be a constant rate and the graph will be in the form of a zigzag. But if it is linear, it will go up or come down at a constant rate.

As can be seen in Figure 15, under the theme of Reasoning, the students who had a proper understanding of the concept of linearity constructed some arguments such as "it continuously increases, decreases or remains steady" and "there should be a constant rate between the terms for linearity". Also, based on these arguments, they reached generalizations about linearity using statements such as 'the constant difference between the terms', 'an increase or decrease in the terms in a certain pattern or terms being in a constant state', or 'a constant rate between the terms'.

Some of the students who understood or did not understand the concept $\left(\mathrm{H}_{3}, \mathrm{M}_{1}\right.$ and $\mathrm{M}_{5}$ ) gave answers by generalizing the concept of linear relationships in association with the concept of right proportions. Student $\mathrm{M}_{5}$, for instance, made the following explanation:

R: What do you think linearity means?

$\mathrm{M}_{5}$ : It is linear when something increases when something else increases as well.

$\mathrm{R}:$ Does it only apply to an increase?

$M_{5}$ : No. It is the same in case of a decrease, too.

As can be seen in Figure 15, one student with a high level of achievement $\left(\mathrm{H}_{4}\right)$ and three students with a middle level of achievement $\left(M_{1}, M_{2}\right.$ and $\left.M_{4}\right)$ gave incorrect 
answers about the concept of linearity. Focusing on situations of proportion in the linear equations, these students either stated that only equations in the form of $y=m x$ were linear or associated obtaining $y$ values against $x$ values with linearity. In the light of this, they constructed arguments such as "those passing through the origin are always linear, $\mathrm{x} / \mathrm{y}$ should always be equal, or $\mathrm{y} / \mathrm{x}$ is undefined" or "it involves obtaining $y$ against each value of $x$ ". Obviously, these students incorrectly generalized linearity to equations in the form of $y=m x$ or as obtaining a $y$ value against each value of $x$. The following are some examples illustrating this situation:

R: Now, how would you answer if I asked you whether $y=3 x+10$ is linear or not?

$\mathrm{M}_{4}$ : It is linear if it passes through the origin and it is not linear if it does not. This one is not linear because it does not pass through the origin.

Student $\mathrm{M}_{1}$ gave a similar answer:

R: How would you answer if I asked you whether $y=2 x^{2}$ or $y=3 x+10$ equations are linear?

$\mathrm{M}_{1}$ : I think $\mathrm{y}=2 \mathrm{x}^{2}$ equations are linear.

A. Why do you think so?

$\mathrm{M}_{1}$ : The other one has a constant number. It has the number 10 . That is why it is not linear.

Below is the answer given by student $\mathrm{H}_{4}$ :

$\mathrm{R}$ : Which one of the equations given in the problem do you think makes a linear relationship?

$\mathrm{H}_{4}$ : Only item (b).

$\mathrm{R}:$ Why is that?

$\mathrm{H}_{4}$ : Because it should always be the same number when we divide $\mathrm{x}$ values by $\mathrm{y}$ values. This is true only for item (b).

After all, despite having the exact opposite approach to the approach of student $\mathrm{H}_{4}$, $\mathrm{M}_{2}$ stated that only item (b) was linear and made following comment:

$\mathrm{R}$ : Which one of the equations given in the problem do you think makes a linear relationship?

$\mathrm{M}_{2}$ : Only item (b). $\mathrm{y}=5 \mathrm{x}+10$ is not linear because $\mathrm{y} / \mathrm{x}$ is undefined, 15 divided by 1 makes 15 (writing on the problem), 20 divided by 2 makes 10, 25 divided by 3 makes 8 point something. I mean, there is not an exact rate.

Finally, student $M_{1}$ explained how he/she perceived the concept of linearity by saying, "they are linear because I always get a value of y no matter what I assign as a value of $\mathrm{x}$. For example, if I take $\mathrm{y}$ as 20 in $\mathrm{y}=5 \mathrm{x}^{2} \mathrm{I}$ get $\mathrm{x}=2$ from $4=\mathrm{x}^{2 \text { " }}$. We also observed that the students used inductive, deductive and proportional types of reasoning throughout all this process.

\section{Discussion, Conclusion and Recommendations}

Our quantitative findings showed that more than half of the students (54.36\%) had low levels of achievement regarding the concepts of linear functions and the 
slope. The open-ended design of the algebra test, the students' high familiarity with multiple choice exams and prevalence of exam-oriented teaching practices at schools in Turkey could be the reasons. Research has shown that mathematics instruction tended to focus more on students' operational knowledge rather than their conceptual knowledge of algebraic concepts (Baki \& Kartal, 2004). In fact, when each of the problems and practice questions in the algebra test was assessed separately in terms of conceptual understanding, the results supported this situation, and these results suggested that the students did not have an adequate level of conceptual understanding of the concepts of linear functions and the slope. One indicator of this situation was the fact that the given problems and practice questions were not solved correctly by the majority of the students. What is more, the qualitative results obtained in order to deeply examine the conceptual understanding and reasoning indicators of the concepts of linear functions and the slope supported the quantitative results. However, in order to avoid making too broad a generalization, we should keep in mind that the qualitative results in the study were collected from 10 students - five students with a high level of achievement and five students with a middle level of achievement.

The qualitative findings showed that there were few students who were able to solve the problem situations and practice questions correctly, but they had a high level of achievement. These students clearly had an adequate level of conceptual understanding in relation to analyzing and solving real life problems, understanding the meaning of a representation as a whole and parts of it, using multiple representation and relating them with problem situations, and switching between representations. In addition, considering the forefront role of reasoning skills in realizing conceptual understanding, the students who were good at conceptual understanding had also a good level of reasoning skills in terms of constructing arguments, reaching generalizations, and evaluating and supporting results. Therefore, this result is similar to other research findings showing that understanding and reasoning were related to and supported each other (Ball \& Bass, 2003; Cheng, 2010).

The analysis of the students' conceptual knowledge and their knowledge of representations about the concepts of the slope, rate of change and linear relationships in the context of conceptual understanding revealed that the majority of the students in our study had difficulty in finding the slope of a line and they thought the slope would change in parallel with the change of the points on a line. Similarly, Postelnicu (2011) found that students had most difficulties in determining and interpreting the slope of a line graph.

We also observed that, in general, the students defined the slope using expressions such as "division of horizontal length by vertical length", "slope angle", or "tangent". However, as shown by research (Clement, 1985; Duncan \& Chick, 2013; Stump, 2001b), some students failed to support their definitions and they were not able to make descriptive and logical interpretations. This situation is an indication that some of the students perceived the concept of the slope in operational aspects rather than 
in conceptual aspects. Another result supporting this suggestion was one student's demonstration of the slope's vertical and horizontal length variables on a right triangle model without thinking. This result is consistent with the finding reported by Birgin (2006). In short, as suggested by evidence (Barr, 1981; Hattikudur, Prather, Asquith, Alibali, Knuth, \& Nathan, 2012; Lobato \& Siebert, 2002; Lobato \& Thanheiser, 2002; Planinic et al., 2012; Stump, 2001b; Teuscher \& Reys, 2010), some of the students in our study were not aware of the constancy of the slope on any point in a line and the equality of the constant rate between the slope's vertical and horizontal lengths, and they were misguided by the idea that "as points change on the axis, different lines will occur and, therefore, the slopes of the lines will also change". Nevertheless, we also observed in our study that those students who were aware of the relationship between the slope and rate of change were able to make the necessary confirmations, and they supported their confirmations by using multiple representations in this process.

If we look at our results in terms of linear relationships, we could suggest that some of the students assumed only lines in the form of $y=m x$ and passing through the origin were linear, but those lines in the form of $y=m x+n$ were not linear. Barr (1981) and Moschkovich (1996) found similar results. In addition to the students who were able to support linearity depending on a "constant increase or decrease" between variables, some other students considered linear relationships as "right proportions" and thought it would be enough to have a value increasing/decreasing in parallel to another value increasing/decreasing regardless of a constant rate. Some of our students also attempted to interpret linearity by proportioning variables. We observed that these students evaluated linearity according to the constant value that they obtained by proportioning variables as $\mathrm{y} / \mathrm{x}$ or $\mathrm{x} / \mathrm{y}$ or according to varying values and, in other words, they took proportional situations in linear equations $(\mathrm{y}=\mathrm{mx})$ into consideration but ignored disproportionate situations $(y=m x+n)$. Similarly, Birgin (2006) found that students were not able to determine the relationship between the slope and $\mathrm{x}$ and $y$ variables. Considering the prerequisite role of the rate concept for the slope, the students probably also had difficulty in understanding this concept and, therefore, they were seriously confused about the slope, rate of change and linear relationships. This suggestion is also confirmed by the fact that some of our students expressed the concept of linearity as "obtaining y against each value of $x$ " in a line equation and by their claim that a quadratic equation such as " $y=2 x^{2 "}$ would be linear. Similarly, Stump (2001) and Teuscher and Reys (2010) found that their participants did not have a proper understanding of the rate of change and they had various problems about the concept. In short, these results suggest that our students could not understand the meaning of symbols in line equations, but they merely memorized formulas without developing a deeper understanding of concepts. The presence of similar results in the literature (Anderson, 2008; Barr, 1981; Birgin, 2012; Moschkovich, 1996; Stump, 1999; Teuscher \& Reys, 2010) unfortunately points to the continuous presence of difficulties experienced with these concepts. 
When we look at the results of the students' knowledge of representations on the concepts of linear functions and the slope within the context of conceptual understanding, we could suggest that the students tended to prefer verbal, algebraic, graphical, table, numerical and geometric representations, but their favorite one was verbal representation. However, investigating the extent to which students were able to use symbols and graphical representations for linear functions and how they were able to establish relationships between representations, Knuth (2000) identified algebraic representations as the most widely used among students, and this might have resulted from the curriculum. Although some of the students in our study used multiple representations, they had problems in using these correctly and switching between or interpreting representations. All the students but one had difficulty especially in using graphical and algebraic representations and, as shown by some other studies (Birgin, 2006; Demirci \& Uyanık, 2009; Knuth, 2000; Önür, 2008; Postelnicu, 2011; Reiken, 2008; Teuscher \& Reys, 2010), they tended to draw $y=a, y=m x$ graphs and start the graph from the origin. Also, there were algebraic expressions based on trialand-error method in algebraic representations, which very few of our students made an attempt for. When we look at the results on the students' constructing arguments, making generalizations and supporting the results and preferred types of reasoning in terms of reasoning skills, we could suggest those students who were not good at conceptual understanding were also not good at developing adequate arguments about the concepts of rate of change and linear relationships and supporting their arguments effectively. Moreover, our students generally used several types of reasoning such as recursive (between variables), functional, inductive (through proportional relations), deductive, proportional and abductive reasoning, but very few students made correct judgments.

In conclusion, conceptual understanding does not mean memorizing formulas that allow for performing practical operations or solving problems correctly by using formulas. However, the majority of the students in our study counted on superficial knowledge of the concepts of linear functions and the slope, they mainly stuck to the slope formula and line equation, and they did not possess adequate reasoning skills. Considering the importance of knowledge of representations for conceptual understanding, our students needed improvement in using multiple representations and switching between or interpreting representations. In the light of these, for the development of both conceptual knowledge and reasoning skills, we could suggest that the focus of the teaching-learning process in classroom practices should be on real life problems instead of solving too many exam-type questions. In addition, we should design the teaching-learning environments that encourage students to focus on 'why' and 'how' in discussions, use multiple representations, question, interpret, make logical conclusions, and carry out analysis and synthesis.

This research can be expanded to include students in different grade levels and in different subjects. Also, future research can examine the extent to which 
the mathematics teachers of the selected students are aware of student errors or misconceptions and what kind of the teaching strategy they need to adopt in order to eliminate the identified errors or misconceptions.

\section{References}

Anderson, N. C. (2008). Walk the line: Making sense of $y=m x+$ b. In C. Greenes, \& R. Rubenstein (Eds.), Algebra and Algebraic Thinking in School Mathematics: Seventieth Yearbook (pp. 233-246). Reston, VA: National Council of Teachers of Mathematics.

Baki, A., \& Kartal, T. (2004). Characterizing high school students' algebra knowledge in terms of procedural and conceptual knowledge. Turkish Journal of Educational Sciences, 2(1), 27-46.

Ball, D. L., \& Bass, H. (2003). Making mathematics reasonable in school. A Research Companion to principles and standards for school mathematics. Reston, VA: National Council of Teachers of Mathematics.

Barr, G. (1981). Some student ideas on the concept of gradient. Mathematics in School, 10(1), $14-17$

Blanton, M. L., \& Kaput, J. J. (2005). Characterizing a classroom practice that promotes algebraic reasoning. Journal for Research in Mathematics Education, 36(5), 412-446.

Birgin, O. (2006). Learning levels of elementary school students and possible misconceptions related to the slope of a line. Abstract Book of First National Student Symposium on Mathematics Education, (pp. 47-48). İzmir: Dokuz Eylul University.

Birgin, O. (2012). Investigation of eighth-grade students' understanding of the slope of the linear function. Bolema-Mathematics Education Bulletin, 26(42A), 139-162. https://doi. org/10.1590/S0103-636X2012000100008

Cheng, S. D. (2010). Connecting proportionality and slope: Middle school students' reasoning about steepness. Dissertation Abstracts International. (UMI No: 3405966).

Clement, J. (1985). Misconceptions in graphing. Proceedings of the Ninth International Conference for the Psychology of Mathematics Education, The Netherlands.

Clement, J. (2000). Analysis of clinical interviews: Foundations and model viability. In R. Lesh, \& A. Kelly (Eds.), Handbook of research methodologies for science and mathematics education (pp. 341-385). Hillsdale, NJ: Lawrence Erlbaum.

Crawfort, A. R., \& Scott, W. E. (2000). Making sense of slope. The Mathematics Teacher, 93(2), 114-118.

Creswell, J. W. (1994). Research design: qualitative, quantitative and mixed methods approaches. London: Sage Publications.

Demirci, N., \& Uyanık, F. (2009). The correlation between tenth grade students' understanding and interpreting graphs and their kinematics achievement. Necatibey Faculty of Education Electronic Journal of Science and Mathematics Education, 3(2), 22-51.

Duncan, B., \& Chick, H. L. (2013). How do adults perceive, analyze and measure slope? In 36th annual conference of the Mathematics Educations Research Group of Australasia (MERGA 36) (pp. 258-265). Melbourne, Australia. 
Greenes, C., Chang, K. Y., \& Ben-Chaim, D. (2007). International survey of high school students' understanding of key concepts of linearity. Proceedings of the 31st Conference of the International Group for the Psychology of Mathematics Education, 2, (pp. 273-280). Seoul, Korea.

Hattikudur, S., Prather, R. W., Asquith, P., Alibali, M. W., Knuth, E. J., \& Nathan, M. (2012). Constructing graphical representations: middle schoolers' intuitions and developing knowledge about slope and y-intercept. School Science and Mathematics, 112(4), 230-240. https://doi.org/10.1111/j.1949-8594.2012.00138.x

Hiebert, J., \& Lefevre, P. (1986). Conceptual and procedural knowledge in mathematics: An introductory analysis. In J. Hiebert (Ed.), Conceptual and procedural knowledge: The case of mathematics (pp. 1-27). Hillsdale, NJ: Lawrence Erlbaum.

Kasmer, L. (2008). The role of prediction in teaching and learning of algebra. Dissertation Abstracts International. (UMI Number: 3303469).

Knuth, E. J. (2000). Student understanding of the Cartesian connection: An exploratory study. Journal for Research in Mathematics Education, 31(4), 500-508. https://doi. org/10.2307/749655

Liamputtong, P. (2009). Qualitative research methods. Melbourne: Oxford University Press.

Lobato, J., \& Siebert, D. (2002). Quantitative reasoning in a reconceived view of transfer. The Journal of Mathematical Behavior, 21(1), 87-116. https://doi.org/10.1016/S07323123(02)00105-0

Lobato, J., \& Thanheiser, E. (2002). Developing understanding of ratio as measure as a foundation for slope. Making sense of fractions, ratios, and proportions, 162-175.

MNE (2013). Middle School Mathematics Lesson 5-8. Classes Curriculum. Ankara: State Books Authority Printing House.

Moschkovich, J. N. (1996). Moving up and getting steeper: Negotiating shared descriptions of linear graphs. The Journal of the Learning Sciences, 5(3), 239-277. https://doi.org/10.1207/ $\underline{\text { s15327809jls0503 } 4}$

NCTM. (2000). Principles and standards for school mathematics. Reston, VA: NCTM.

Noh, J. (2004). An investigation of secondary teachers' knowledge of rate of change in the context of teaching a standards-based curriculum. Dissertation Abstracts International. (UMI Number: 3154507).

Onur, Y. (2008). Effects of Graphing Calculators on Eight Grade Students Achievement in Graphs of Linear Equations and Concept of Slope. (Unpublished master dissertation). Middle East Technical University, Ankara.

Owens, D. T. (1993). Research Ideas for the Classroom Middle Grades Mathematics. Reston: NCTM Publications.

Planinic, M., Milin-Sipus, Z., Katic, H., Susac, A., \& Ivanjek, L. (2012). Comparison of student understanding of line graph slope in physics and mathematics. International Journal of Science and Mathematics Education, 10(6), 1393-1414. https://doi.org/10.1007/s10763012-9344-1

Postelnicu, V. (2011). Student difficulties with linearity and linear functions and teachers' understanding of student difficulties. Dissertation Abstracts International. (UMI No: 3450231). 
Reid, D. A., \& Knipping, C. (2010). Proof in mathematics education research. Learning and Teaching. Rotterdam: Sense Publishers.

Reiken, J. J. (2008). Coming to understand slope and the Cartesian connection: An Investigation of student thinking. Dissertation Abstracts International. (UMI Number: 3347606)

Rips, L. J. (1994). The psychology of proof: Deductive reasoning in human thinking. Cambridge, MA: MIT.

Siegler, R. S. (2003). Implications of cognitive science research for mathematics education. In J. Kilpatrick, W. G. Martin, \& D. Schifter (Eds.), A research companion to Principles and Standards for School Mathematics (pp. 289-303). Reston, VA: National Council of Teachers of Mathematics.

Skemp, R. (1987). The psychology of learning mathematics. Hillsdale, NJ: Lawrence Erlbaum Associates.

Soylu, Y., \& Aydin, S. (2006). A study on importance of the conceptual and operational knowledge are balanced in mathematics lessons. Journal of Erzincan Education Faculty, 8(2), 83-95.

Stump, S. L. (1999). Secondary mathematics teachers' knowledge of the concept of slope. Mathematics Education Research Journal, 11(2), 124-144. https://doi.org/10.1007/ $\underline{\text { BF03217065 }}$

Stump, S. L. (2001a). Developing preservice teachers' pedagogical content knowledge of slope. The Journal of Mathematical Behavior, 20(2), 207-227. https://doi.org/10.1016/ S0732-3123(01)00071-2

Stump, S. L. (2001b). High School Precalculus Students' Understanding of Slope as Measure. School Science and Mathematics, 101(2), 81-89. https://doi.org/10.1111/j.1949-8594.2001. tb18009.x

Styliandies, G., \& Silver, E. (2004). Reasoning and proving in school mathematics curricula: An analytic framework for investigating the opportunities offered to students. Paper presented at the Twenty-sixth annual meeting of the North American Chapter of the International Group for the Psychology of Mathematics Education, Toronto, Canada.

Teddlie, C., \& Yu, F. (2007). Mixed methods sampling: A typology with examples. Journal of Mixed Methods Research, 1(1), 77-100.

Tekay, T., \& Dogan, M. (2015). The evaluation of 7th grade primary school students' skills of solving the questions about the graphs of linear equations. MatDer Mathematics Education Journal, 2(1), 1-9.

Teuscher, D., \& Reys, R. E. (2010). Slope, rate of change, and steepness: Do students understand these concepts? Mathematics Teacher, 103(7), 519- 524.

Wilhelm, J. A., \& Confrey, J. (2003). Projecting rate of change in the context of motion onto the context of money. International Journal of Mathematical Education in Science and Technology, 34(6), 887-904. https://doi.org/10.1080/00207390310001606660

Ylldırım, A., \& Simsek, H. (2011). Qualitative research methods in the social sciences. Ankara: Seckin Publisher. 


\section{Dilek Tanışlı}

Anadolu University, Faculty of Education,

Department of Mathematics and Science, Yunus Emre Kampüsü, Anadolu Üniversitesi, Eskişehir, Turkey

dtanisli@anadolu.edu.tr

\section{Deniz Bike Kalkan}

Ministry of National Education of Turkey

Atatürk Middle School, Elmadağ/Ankara, Turkey

dnzbike@gmail.com

\section{APPENDIX}

\section{ALGEBRA TEST EVALUATION CRITERIA and SCORES}

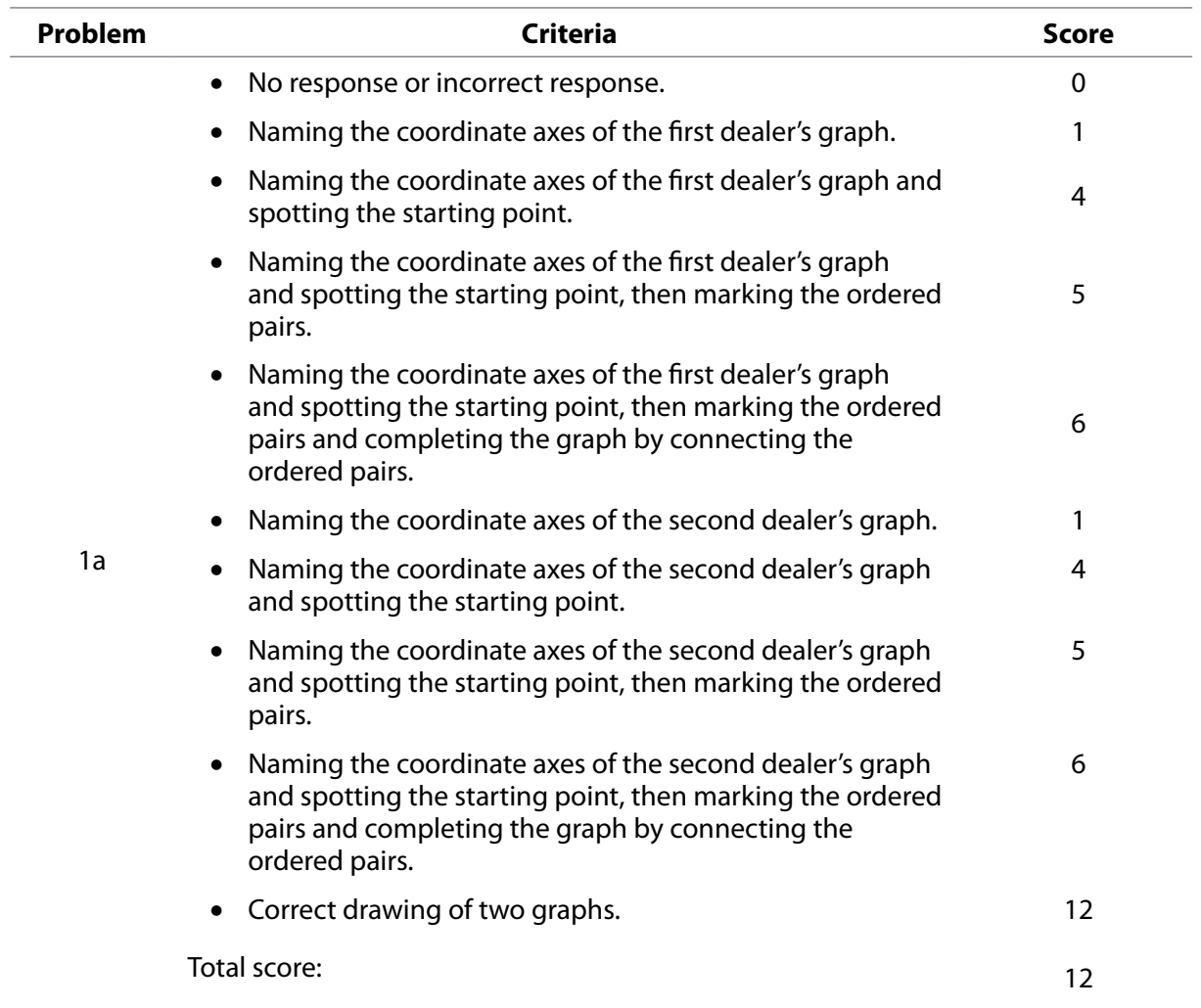




\begin{tabular}{|c|c|c|}
\hline Problem & Criteria & Score \\
\hline \multirow{7}{*}{$1 \mathrm{~b}$} & - No response or incorrect response. & 0 \\
\hline & $\begin{array}{l}\text { - Not being able to identify the common point of two } \\
\text { dealers, yet stating that the second offer is cheaper than } \\
\text { the first offer. }\end{array}$ & 2 \\
\hline & $\begin{array}{l}\text { - Not being able to identify the common point of two } \\
\text { dealers, yet stating that profit depends on the number of } \\
\text { CDs. }\end{array}$ & 4 \\
\hline & $\begin{array}{l}\text { - Without identifying the common point of two dealers, } \\
\text { interpreting just one sample. }\end{array}$ & 6 \\
\hline & - Identifying only the common point. & 6 \\
\hline & $\begin{array}{l}\text { - Identifying the common point via the game/price graph } \\
\text { or table of two dealers and then interpreting. }\end{array}$ & 14 \\
\hline & Total score: & 14 \\
\hline \multirow[t]{5}{*}{ Problem } & Criteria & Score \\
\hline & - No response or incorrect response. & 0 \\
\hline & - Only defining the slope. & 5 \\
\hline & - Interpreting based on the sign of slope. & 5 \\
\hline & $\begin{array}{l}\text { - Interpreting based on the fact whether the selected points } \\
\text { compose the right triangle. }\end{array}$ & 8 \\
\hline \multirow[t]{3}{*}{2} & $\begin{array}{l}\text { - Solution } 1 \text { : Interpreting based on the fact that the two } \\
\text { selected points must be on the same line. }\end{array}$ & 26 \\
\hline & $\begin{array}{l}\text { - Solution 2: Drawing equation graph of " } y=a x+b \text { ", and then } \\
\text { identifying the slope of two points on this graph. }\end{array}$ & 26 \\
\hline & Total score: & 26 \\
\hline \multirow[t]{3}{*}{ Problem } & Criteria & Score \\
\hline & - No response or incorrect response. & 0 \\
\hline & - Solution 1: Completing the table by counting rhythmically. & 4 \\
\hline \multirow[t]{2}{*}{$3 a$} & $\begin{array}{l}\text { - Solution 2: Completing the table using the arithmetic } \\
\text { sequence formula. }\end{array}$ & 4 \\
\hline & Total score: & 4 \\
\hline \multirow[t]{3}{*}{ Problem } & Criteria & Score \\
\hline & - No response or incorrect response. & 0 \\
\hline & - Finding incorrect results due to calculation error. & 2 \\
\hline \multirow[t]{2}{*}{$3 b$} & - Completing the table by counting down rhythmically. & 4 \\
\hline & Total score: & 4 \\
\hline
\end{tabular}




\begin{tabular}{|c|c|c|}
\hline Problem & Criteria & Score \\
\hline \multirow{4}{*}{$3 c$} & - No response or incorrect response. & 0 \\
\hline & - Verbal expression of proportion. & 3 \\
\hline & - Achieving the right result with proportion. & 6 \\
\hline & Total score: & 6 \\
\hline Problem & Criteria & Score \\
\hline \multirow{3}{*}{$3 d$} & - No response or incorrect response. & 0 \\
\hline & - Finding a formula. & 10 \\
\hline & Total score: & 10 \\
\hline Problem & Criteria & Score \\
\hline \multirow{4}{*}{$4 a / b / c$} & - No response or incorrect response. & 0 \\
\hline & - Misplacing the variables. & 2 \\
\hline & - Finding y value from $x$ value. & 4 \\
\hline & Total score: & 4 \\
\hline Problem & Criteria & Score \\
\hline \multirow{4}{*}{$4 d_{i}$} & - No response or incorrect interpretations. & 0 \\
\hline & $\begin{array}{l}\text { - Solution 1: Interpreting on linearity based on the constant } \\
\text { difference. }\end{array}$ & 6 \\
\hline & $\begin{array}{l}\text { - Solution 2: Interpreting on linearity by drawing a graph or } \\
\text { table. }\end{array}$ & 6 \\
\hline & Total score: & 6 \\
\hline Problem & Criteria & Score \\
\hline \multirow{5}{*}{$4 d_{i i}$} & - No response or incorrect response. & 0 \\
\hline & - Interpreting linearity based on the data in table. & 3 \\
\hline & - Interpreting linearity based on the equation. & 3 \\
\hline & $\begin{array}{l}\text { - Interpreting the linearity based on both the table and the } \\
\text { equation. }\end{array}$ & 6 \\
\hline & Total score: & 6 \\
\hline
\end{tabular}




\section{Linearne funkcije i nagib pravca: kako učenici shvaćaju te pojmove i kako razmišljanje djeluje na njihovo razumijevanje?}

\section{Sažetak}

Cilj ovog istraživanja jest ispitati konceptualno razumijevanje učenika osmog razreda, načine razmišljanja o linearnim funkcijama i nagibu pravca. U istraživanju se koristila mješovita metoda. Kvantitativni podatci prikupljali su se s pomoću testa iz algebre, a kvalitativni podatci prikupljali su se s pomoću kliničkih intervjua. $U$ kvantitativnom dijelu istraživanja sudjelovala su 103 učenika, a u kvalitativnom dijelu 10 učenika koji su bili odabrani između ta 103 učenika, a imali su visoku $i$ srednju razinu postignuća. Kvantitativni podatci bili su procijenjeni na temelju liste točnih odgovora, a takoder su izračunate i interpretirane frekvencije za te odgovore. Većina učenika računala je na površno znanje o linearnim funkcijama i nagibu pravca te su se uglavnom pridržavali formula za koeficijent smjera pravca i jednadžbe pravca, a nisu ovladali ispravnim vrstama razmišljanja. Također je bilo potrebno popraviti način na koji se koriste raznovrsnim prikazima i interpretiraju ih.

Ključne riječi: konceptualno razumijevanje; nastava matematike; učenici osnovne škole.

\section{Uvod}

Što znači učiti matematiku? Odgovor na to pitanje daju mnoge teorije koje se bave načinima na koje ljudi uče. Na primjer, i konstruktivistička i sociokulturalna teorija naglašavaju važnost uspostavljanja veze između novih informacija i prethodno usvojenoga znanja u procesu učenja. Mjerenje kvalitete i kvantitete te veze između novih informacija i postojećega znanja naglašava važnost „konceptualnog razumijevanja”. Konceptualno je razumijevanje znanje o temeljnim idejama i odnosima vezanima uz određenu temu (Van de Walle, Karp i Bay-Williams, 2012). „Razmišljanjem” se to konceptualno znanje utvrđuje. Razmišljanje je mentalni proces tijekom kojega se od postojećeg znanja stvaraju nova znanja (Rips, 1994). Učinkovito upravljanje tim procesom vodi dubljem razumijevanju matematičkih pojmova, a kod učenika ulijeva sigurnost u matematičkim operacijama i sprečava učenje napamet. Stoga možemo 
tvrditi da su konceptualno razumijevanje i razmišljanje međusobno isprepleteni pojmovi u učenju matematike (Ball i Bass, 2003; Kasmer, 2008; Siegler, 2003).

Matematika je skup pojmova i međusobnih veza između tih pojmova. Mnogi od međusobno isprepletenih pojmova sami od sebe stvaraju osnovu za usvajanje novih pojmova. Stoga, ako učenici određeni pojam ne shvate ispravno, to može utjecati na razumijevanje mnogih drugih pojmova. $U$ tom su smislu linearne funkcije i nagib pravca ključni pojmovi jer su ujedno i preduvjeti za neke druge matematičke pojmove i za shvaćanje raznovrsnih situacija iz svakodnevnog života. Linearne su funkcije podskup promjenjivih linearnih obrazaca i funkcija. Linearnost, koja se prikazuje putem promjenjivih linearnih obrazaca u nižim razredima osnovne škole, središte je matematike u višim razredima osnovne škole. Linearne funkcije mogu se opisati kao one čiji je graf ili ravni pravac ili pravac koji konstantno raste. Analiza promjene jedna je od četiriju standarda algebre (NCTM, 2000). Stopa (konstantna ili promjenjiva) odnosi se na vrstu promjene koja opisuje kako se brzo nešto kreće te je prilično dobar kontekst za proučavanje linearnosti. Nagib pravca definiran je kao „numerička vrijednost koja prikazuje stopu promjene linearne funkcije”, kao „omjer okomitih i vodoravnim promjena između dviju točaka na pravcu (geometrijski omjer) ili kao „vrijednost tangensa bilo kojega kuta koji ravni pravac čini s pozitivnim smjerom osi x (trigonometrijski pojam)" (Stump, 1999; Van de Walle, Karp i Bay-Williams, 2012). Veza između tih različitih vrsta prikaza promiče bolje konceptualno razumijevanje nagiba pravca.

Linearne funkcije i nagib pravca su poddomene algebarskih sadržaja u turskom kurikulu za nastavu matematike u višim razredima osnovne škole. Uglavnom se spominju u sedmom i osmom razredu. Kurikul za sedmi razred ima nastavnu cjelinu u kojoj se od učenika očekuje da prepoznaju koordinatni sustav; prikažu promjene varijable s pomoću druge varijable s kojom ima linearni odnos, koristeći se tablicama, grafovima i jednadžbama, kao i napraviti skicu grafa linearnih jednadžbi. U osmom razredu nastavne cjelinu uključuju ispitivanje linearnog odnosa između dviju varijabli; određivanje nagiba pravca i ispitivanje odnosa između linearnih jednadžbi, grafova i tablica, obraćajući pažnju na značenje nagiba pravca (MNE, 2013).

Istraživanja su pokazala da su učenici imali poteškoća s razumijevanjem i linearnih funkcija i nagiba pravca, kao i da su imali različite krive predodžbe o tim pojmovima (Barr, 1981; Duncan i Chick, 2013; Greenes, Chang i Ben-Chaim, 2007; Planinic, MilinSipus, Kati, Susac i Ivanjek, 2012; Postelnicu, 2011; Stump, 2001b; Wilhelm i Confrey, 2003). Nadalje, čak su i nastavnici imali poteškoća u prepoznavanju veza između različitih vrsta prikaza nagiba pravca (Stump, 1999). Važnija istraživanja obično se provode na uzorku srednjoškolaca ili studenata. Najčešći je izazov taj što učenici ne posjeduju konceptualno razumijevanje o nagibu pravca i stopi promjene, a teško im je i prepoznati vezu između njih (Barr, 1981; Crawfort i Scott, 2000; Greenes, Chang i BenChaim, 2007; Planinic, Milin-Sipus, Kati, Susac i Ivanjek, 2012; Postelnicu, 2011; Stump, 2001b). Barr (1981) je, na primjer, ukazao na neke poteškoće pri učenju o nagibu pravca: 
- Zbunjenost činjenicom da se nagib pravca može smatrati omjerom,

- Zbunjenost pojmovima „x kroz y” ili „y kroz x” kada se analizira nagib pravca s dvije zadane točke,

- Nejasnoće o tome na što se odnose „m” $i$ „c" u općim jednadžbama ravnog pravca $\mathrm{u} y=\mathrm{mx}+\mathrm{c}, \mathrm{i}$

- Nemogućnost prepoznavanja nagiba pravca kada su zadane dvije točke.

Istraživanja su također pokazala i neke druge ozbiljne poteškoće: analiziranje nagiba pravca samo uz pomoć pojmova „visina” ili „kut” (Clement, 1985; Duncan i Chick, 2013; Stump, 2001b); nejasnoće kod mjerenja visine i računanja stope promjene (Teuscher i Reys, 2010); nejasnoće u značenju simbola zbog sklonosti računanju nagiba pravca i učenju formula za izračunavanje nagiba pravca napamet (Barr, 1981; Moschkovich, 1996; Stump, 1999); nemogućnost crtanja grafa pravca i njegove interpretacije, procjene stope promjene i nagiba pravca na temelju grafa pravca i nemogućnost razlikovanja pozitivnog i negativnog nagiba pravca (Birgin, 2006; Knuth, 2000; Önür, 2008; Postelnicu, 2011; Reiken, 2008; Teuscher i Reys, 2010). Na primjer, $\mathrm{u}$ istraživanju u kojemu su učenici sedmog razreda osnovne škole procjenjivali svoju sposobnost odgovaranja na pitanja o grafovima linearnih jednadžbi uočeno je da su se učenici ograničili na crtanje grafova linearnih jednadžbi u kojima se sijeku osi, na izradu tablica vrijednosti i na pokazivanje koordinata zadane točke u Kartezijevu koordinatnom sustavu (Tekay i Doğan, 2015). Nadalje, u jednom drugom istraživanju o shvaćanju nagiba pravca linearne funkcije u kojemu su sudjelovali učenici osmoga razreda osnovne škole, Birgin (2012) je utvrdio da su učenici manje uspješni u izračunavanju nagiba pravca kod transformacije algebarskih i grafičkih prikaza nego u izračunavanja nagiba pravca samo s pomoću algebarskih prikaza. $U$ ovom je istraživanju uočeno da neki učenici imaju poteškoća s jednadžbama, grafovima i nagibom pravca linearne funkcije, kao i da imaju mnoge pogrešne predodžbe. Također, učenici ne mogu pronaći vezu između nagiba pravca i točki na osima x i y u grafovima linearnih jednadžbi. Usprkos tome, razmatrajući važnost veze između razumijevanja stope promjene i nagiba pravca i razmišljanja, Cheng (2010) tvrdi da postoji pozitivna veza između nagiba pravca i proporcionalnog razmišljanja na temelju razmišljanja učenika o kosini nagiba pravca.

Postoji potreba za istraživanjima koja bi ispitala kako učenici u višim razredima osnovne škole, kada se linearne funkcije i nagib pravca formalno uvode, shvaćaju te pojmove i kojim se načinima razmišljanja koriste. Ovo istraživanje utemeljeno je upravo na toj potrebi. Stoga je cilj ovog istraživanja odrediti razinu postignuća učenika osmog razreda u području linearnih funkcija i nagiba pravca te ispitati njihovo konceptualno razumijevanje i načine razmišljanja. Ovo su bila pitanja postavljena u istraživanju:

1. Kakvu razinu postignuća imaju učenici osmog razreda u području linearnih funkcija i nagiba pravca? 
2. Kakvo je konceptualno razumijevanje učenika osmog razreda kada se radi o linearnim funkcijama i nagibu pravca te kakvim se načinima razmišljanja pri tome koriste?

Ispitujući konceptualno razumijevanje učenika osmog razreda, kada se radi o linearnim funkcijama i nagibu pravca, kao i načinu razmišljanja o tim pojmovima, ovo je istraživanje bilo usmjereno na način na koji učenici viših razreda osnovne škole shvaćaju te pojmove. U tom bi smislu određivanje utjecaja tih poteškoća na proces učenja novog znanja kod učenika moglo doprinijeti nastavnom procesu, jer su linearne funkcije i nagib pravca ključni pojmovi i preduvjeti za neke druge matematičke pojmove. Učenici koji ih ne mogu ispravno shvatiti imaju poteškoća u shvaćanju ostalih pojmova koji slijede. Uočavanje načina na koji učenici shvaćaju t pojmove moglo bi biti korisno u nastavi matematike, pogotovo u području algebre. Na kraju, rezultati ovog istraživanja mogli bi poslužiti kao smjernice za istraživanja koja će provesti nastavnici matematike.

\section{Okvir za konceptualno razumijevanje i razmišljanje}

Konceptualno razumijevanje najbolji je način shvaćanja i vježbanja matematike, koja ima apstraktnu strukturu. Uspostavljanje veza između matematičkih pojmova, operacija i odnosa bitno je za konceptualno razumijevanje. Stoga se može reći da konceptualno razumijevanje podrazumijeva sposobnost upotrebe matematičkih operacija, pojmova i procesa. Hiebert i Lefevre (1986) definirali su konceptualno razumijevanje kao bogato znanje o vezama. Van de Walle i sur. (2012) definirali su ga kao znanje povezano s osnovnim idejama o odnosima između neke teme ili pojma. Konceptualno razumijevanje može se smatrati međusobno povezanim znanjem; ako učenik može stvoriti vezu s ostalim dijelovima znanja, onda se to smatra konceptualnim razumijevanjem (Skemp, 1987). U konceptualnom razumijevanju nije dovoljno samo prepoznati pojam ili znati njegovu definiciju i ime, nego je također potrebno uočiti međusobne prijelaze i veze među pojmovima (Soylu i Aydın, 2006).

Proces ispitivanja i promišljanja kod učenika, tj. njihova vještina razmišljanja, ima ključnu ulogu u procesu konceptualnog razumijevanja. NCTM (2000) opisuje razmišljanje putem faze stvaranja matematičkih pretpostavki i razvijanja $\mathrm{i}$ procjenjivanja matematičkih argumenata, a zatim naglašava važnost razmišljanja za znanje o matematici i njezino razumijevanje. Blanton i Kaput (2005) definirali su algebarsko razmišljanje, dio matematičkog razmišljanja, kao „proces u kojemu učenici generaliziraju matematičke ideje iz određenog broja primjera, utvrđuju te generalizacije putem diskursa i argumentacije te ih izražavaju na sve službeniji i zreliji način koji odgovara njihovoj dobi” (str. 413). Blanton i Kaput (2005) također su smatrali da se zadatci koji zahtijevaju algebarsko razmišljanje trebaju uklopiti u svakodnevnu strukturu nastavnih sati matematike. Općenito gledajući, matematičko razmišljanje navodi učenike na to da kritički promišljaju, i samostalno, i u skupinama. Taj proces uključuje usmjeravanje kod pronalaženja razloga za ono što se nalazi u srži 
teških matematičkih problema, učenički proces stvaranja, kao i opis i obrazloženje novih matematičkih ideja. Postoji veliko slaganje među nastavnicima matematike o tome da je matematičko razmišljanje ključno za cjelokupno iskustvo učenja (Stylianides i Silver, 2004).

Važno je prepoznati da, kod učenja, konceptualno razumijevanje i matematičko razmišljanje ne isključuju jedno drugo, nego su povezani. Kasmer (2008) je pokazao da konceptualno razumijevanje pozitivno utječe na razvoj razmišljanja, jednako kao što razmišljanje pozitivno utječe na konceptualno razumijevanje. Ball i Bass (2003) smatraju da matematičko razumijevanje ne bi bilo moguće bez razmišljanja. Stoga konceptualno razumijevanje i razmišljanje imaju ključnu ulogu u boljim postignućima učenika u nastavi matematike, u smanjivanju količine poteškoća koje učenici imaju u matematici te u izbjegavanju stvaranja krivih predodžbi. U ovom se istraživanju konceptualno razumijevanje i razmišljanje smatraju međusobno povezanim pojmovima. Kasmer (2008) je uveo okvir s pomoću kojega je objasnio razmišljanje i konceptualno razumijevanje. U ovom su se istraživanju neki od Kasmerovih (2008) pokazatelja razmišljanja i konceptualnog razumijevanja koristili u analizi podataka (Tablica 1 i 2). Isto tako, podatci su analizirani prema jednom od pokazatelja razmišljanja $\mathrm{R}(4)$ (Tablica 1) koji obuhvaća induktivno, deduktivno, abduktivno i proporcionalno razmišljanje. $U$ ovom se istraživanju deduktivno razmišljanje odnosi na primjenu općenitog pravila kako bi se donio zaključak o određenom rezultatu; s druge strane, induktivno razmišljanje polazi od određenog slučaja i ide prema stvaranju zaključka o općenitom pravilu. Nadalje, abduktivno razmišljanje polazi od proučavanja neobičnog slučaja i vodi prema stvaranju novoga pravila koje taj određeni slučaj čini manje neobičnim (Reid i Knipping, 2010). Proporcionalno razmišljanje definira se kao prepoznavanje proporcionalnih i neproporcionalnih situacija (Owens, 1993). Stoga, koristeći se tim pokazateljima, možemo stvoriti zaključke i pouzdano procijeniti konceptualno razumijevanje i razmišljanje učenika o linearnim jednadžbama i nagibu pravca.

Tablica 1

Pokazatelji procesa razmišljanja

Pokazatelji procesa razmišljanja

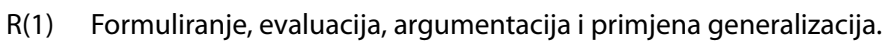

R(2) Izrada, evaluacija i obrazloženje/odbacivanje matematičkih argumenata.

$\mathrm{R}(3) \quad$ Analiza/evaluacija problemske situacije.

R(4) Primjena induktivnog/deduktivnog razmišljanja pri utvrđivanju/objašnjavanju matematičkih veza.

R(5) Razumijevanje s pomoću različitih vrsta razmišljanja/ideja/pristupa i njihovo obrazlaganje.

R(6) Postavljanje pitanja i izazova u situacijama kada se neki pojmovi nepravilno shvaćaju ili kada u vezi s njima ne postoji slaganje.

$R(7) \quad$ Crtanje i obrazlaganje zaključaka u različitim temama. 
Tablica 2

Pokazatelji konceptualnog razumijevanja

\begin{tabular}{|c|c|}
\hline \multicolumn{2}{|r|}{ Pokazatelji konceptualnog razumijevanja } \\
\hline $\mathrm{U}(1)$ & Prikazivanje obrazaca u tablicama, grafovima i s pomoću riječi i jednadžbi. \\
\hline $\mathrm{U}(2)$ & Razumijevanje i prepoznavanje obrazaca kao linearnih, eksponencijalnih itd. \\
\hline $\mathrm{U}(3)$ & $\begin{array}{l}\text { Razumijevanje značenja prikaza (jednadžbi, tablica ili grafova) kao cjeline i kao } \\
\text { pojedinačnih dijelova. }\end{array}$ \\
\hline $\mathrm{U}(4)$ & Razumijevanje i korištenje veza između tablice, jednadžbe i grafa. \\
\hline $\mathrm{U}(5)$ & $\begin{array}{l}\text { Korištenje jednadžbi, grafova i tablica kako bi se riješili problemski zadatci i } \\
\text { odgovori povezali s problemskim situacijama. }\end{array}$ \\
\hline $\mathrm{U}(6)$ & $\begin{array}{l}\text { Prepoznati obrazac u tablici/grafu i njime se koristiti u predviđanju određenog } \\
\text { slučaja. }\end{array}$ \\
\hline $\mathrm{U}(7)$ & $\begin{array}{l}\text { Prepoznati i usporediti karakteristike tablica, grafova i jednadžbi linearnih i } \\
\text { nelinearnih veza. }\end{array}$ \\
\hline
\end{tabular}

\section{Metode \\ Dizajn istraživanja}

U ovom istraživanju koristio se dizajn mješovitih metoda, koji uključuje kombinaciju kvalitativnih i kvantitativnih podataka, metoda, metodologija i/ili paradigmi (Creswell, 1994). Glavni razlog primjene takvog dizajna istraživanja bio je odrediti razine postignuća učenika povezanih s linearnim funkcijama i nagibom pravca, $s$ većim brojem sudionika i primjenom kvantitativnih metoda. Svrha prikupljanja kvantitativnih podataka bila je obrazložiti kvalitativne podatke, a ne stvarati generalizacije. Usprkos tome, detaljno ispitivanje razine konceptualnog razumijevanja i razmišljanja kod učenika s različitim razinama postignuća, a u vezi s tim pojmovima, zahtijeva primjenu kvalitativnih metoda istraživanja.

\section{Sudionici}

Sudionici su odabrani među učenicima osmih razreda u Turskoj koji su pohađali državne škole s prosječnim socioekonomskim statusom. Uzorak u kvantitativnom dijelu istraživanja sastojao se od 103 učenika koji su bili voljni sudjelovati u ovom istraživanju, a uzorak u kvalitativnom dijelu istraživanja sastojao se od 10 učenika koji su odabrani između ta 103 učenika. Sudionici u kvantitativnom dijelu istraživanja odabrani su s pomoću metode prigodnog uzorka (Teddlie i Yu, 2007). Tako je istraživanje najprije uključilo učenike osmoga razreda koji su u njemu bili voljni sudjelovati, a koji su pohađali dvije različite državne škole sa sličnim socioekonomskim uvjetima rada. Za kvalitativni dio istraživanja sudionici su odabrani metodom uzorkovanja prema kriteriju, što je prema vrsti strategija namjernog uzorkovanja (Yıldırım i Şimşek, 2005). Unaprijed određeni kriterij važnosti bio je da je svaki odabrani učenik imao visok ili srednji stupanj postignuća prema broju bodova koje je ostvario na algebarskom testu otvorenoga tipa. Taj je kriterij bio važan kako bi se odredilo postoje li zajednički ili različiti fenomeni u različitim situacijama. 


\section{Prikupljanje podataka}

Kvantitativni podatci prikupljeni su s pomoću algebarskog testa otvorenoga tipa, a kvalitativni su podatci prikupljeni s pomoću kliničkog intervjua (Clement, 2000). Test iz algebre sastojao se od ukupno 12 pitanja s potpitanjima. Tada je proveden pilot-test na uzorku od 32 učenika osmog razreda. Nakon toga je test proveden sa 103 sudionika unutar jednoga školskog sata u dvije škole koje su imale prosječan socioekonomski status. Kako bi se izmjerila pouzdanost testa, najprije je pripremljena lista s točnim odgovorima za svako pitanje u testu te je određen broj bodova za svako pitanje. U procesu izračunavanja bodova maksimalan je broj bodova koji su se mogli ostvariti na testu bio ravnomjerno distribuiran prema stupnju važnosti i težini svakog problema. Ukupan broj bodova na svakom pitanju nakon toga je ponovno izračunat, prema odgovorima učenika (vidi Dodatak), što je bilo izravno proporcionalno vještini mjerenja težine problema. Na kraju tog procesa ukupan su rezultat neovisno izračunala dva stručnjaka. Veza između dviju procjena rezultata testa analizirana je na temelju razmatranja alfa koeficijenta pouzdanosti i stupnja slaganja dvaju neovisnih promatrača. Alfa koeficijent pouzdanosti iznosio je $\alpha=0,805$. Stupanj slaganja između dvaju stručnjaka ispitan je Kendalovim tau koeficijentom, koji je iznosio 0,932 . Tako je rezultat analize pokazao da se većina rezultata procijenjenih od dvaju neovisnih stručnjaka podudara.

Najprije su izrađena pitanja za klinički intervju na temelju testa iz algebre. U vezi s njima pripremljena su neka alternativna i probna pitanja. Osim pitanja u testu iz algebre klinički intervju sadrži i neka druga pitanja kako bi se ispitalo konceptualno razumijevanje i razmišljanje učenika vezano uz linearne veze, stopu promjene, jednadžbe, nagib pravca i njegove tablice, grafove i interpretaciju. Na kraju je provedeno pilot-istraživanje na skupini učenika osmoga razreda s ciljem testiranja i pripreme pitanja za klinički intervju. Klinički intervju odrađen je s deset učenika koji su odabrani među učenicima s visokim i srednjim postignućem s obzirom na rezultate ostvarene na algebarskom testu. Istraživači su bili objektivni u planiranju i provedbi procesa u svim fazama istraživanja. Prikazano je objektivno stajalište, a istraživač, $u$ ulozi voditelja intervjua, intervjuirao je učenika. Postavljao je pitanja kako bi ispitao način razmišljanja učenika, bez požurivanja.

\section{Analiza podataka}

Tijekom analize kvantitativnih podataka, što je bila prva faza istraživanja, pripremljena je lista s točnim odgovorima za svaki od problemskih zadataka u testu iz algebre, a odgovori učenika izračunati su prema ciljnim pokazateljima (Tablica 3 ).

Tablica 3

Zatim su rezultati učenika kategorizirani u tri skupine: visoki $(\mathrm{H})$ rezultati (oni između 77 i 50), srednji (M) rezultati (oni između 49 i 25) i niski (L) (rezultati između 24 i 0 ). Na kraju su izračunate i interpretirane frekvencije ukupnog rezultata učenika. 
Kvalitativni podatci analizirani su s pomoću tehnike tematske analize (Liamputtong, 2009). U procesu analize razmatrani su pokazatelji konceptualnog razumijevanja i razmišljanja koji su prezentirani u teorijskom okviru. Najprije su dva stručnjaka zasebno definirala prve početne kodove. Izračunata je pouzdanost kodiranja i utvrđeno je da je njezina vrijednost $90 \%$. Nakon procesa kodiranja određene su glavne teme i podteme, kao i konsenzus u vezi s njima.

Tablica 4

Teme rješenja učenika osmog razreda

\begin{tabular}{cc}
\hline $\begin{array}{c}\text { Učeničke strategije } \\
\text { rješavanja problema } \\
\text { (Teme) }\end{array}$ & Podteme \\
\hline Razmišljanje & Konstruiranje matematičkih argumenata \\
Generalizacija \\
Evaluacija i objašnjavanje rezultata \\
Vrste razmišljanja
\end{tabular}

Kako se može vidjeti u tablici 4, određene su teme Razmišljanje i Razumijevanje i prikazivanje, a unutar njih izrađeno je 10 podtema. Kada su prezentirani rezultati s izravnim citatima odgovora sudionika, raspravljalo se o vezi između tema i podtema unutar područja grafa pravca, nagiba pravca, funkcijske veze i linearnosti.

Ovo je jedan primjer procesa prepoznavanja kodova, tema i podtema $u$ analizi podataka. Na primjer, razmišljanja svakog učenika, poput: „budući da se točke na pravcu nastavljaju konstantnom stopom promjene, nagib je isti za sve točke na pravcu", „točke na istom pravcu imaju jednaki kut nagiba”, ,u jednadžbi $y=m x+n$ varijable se mijenjaju, ali $m$ ostaje isti” $i$ "nagib se mijenja ovisno o odabranoj točki”, odnose se na kod $\mathrm{u}$ ispitivanju kako učenici shvaćaju nagib pravca. $U$ isto vrijeme, učeničke generalizacije o nagibu pravca kao što su „okomiti kroz vertikalni” i „tangens kuta” odredile su podtemu „generalizacija”. Poslije su dvije podteme kategorizirane pod temu „Razmišljanje”. Sličan je proces proveden za temu Razumijevanje i prikazivanje. Učenička razmišljanja koja su uslijedila iz premisa poput „vertikalni kroz okomiti” i „tangens kuta” kategorizirana su pod temu „deduktivno razmišljanje”.

\section{Rezultati}

Kvantitativni rezultati povezani s konceptualnim razumijevanjem i razinom razmišljanja o linearnim funkcijama i nagibu pravca 
Tablica 5 pokazuje frekvenciju i postotak distribucije ukupnog rezultata učenika osmog razreda na testu iz algebre.

\section{Tablica 5}

Kako se može vidjeti u tablici 5, 54,36 \% učenika imalo je rezultat između 0 i 24 , $29,12 \%$ učenika imalo je rezultat između 25 i 49 , a njih 15,53 \% imalo je rezultat između 50 i 77. Ti rasponi u rezultatima zatim su kategorizirani (svaki pojedinačno) kao nisko, srednje i visoko postignuće. Kako bi se dobio detaljniji opis onoga gdje su učenici imali najviše poteškoća s pojmovima, svaki od problemskih zadataka i svako pitanje za vježbu u testu iz algebre bilo je evaluirano zasebno. Tablica 6 pokazuje rezultate te evaluacije.

U prvom problemskom pitanju u testu iz algebre (Prikaz 1), učenici su trebali s pomoću grafova prikazati situaciju iz svakodnevnog života, izraziti vezu između količina u grafu te povezati odgovore s problemskom situacijom i interpretirati ih.

4. Ahmet vodi trgovinu videoigricama u susjedstvu. Ahmet naplaćuje 3 lire za iznajmljivanje videoigrice. Nakon nekog vremena Mete također otvara trgovinu s videoigricama pokraj Ahmetove te počinje naplaćivati 2 lire za iznajmljivanje videoigrice. Nakon nekog vremena, Ahmetovi kupci počinju uzimati videoigrice u Meteovoj trgovini. Nadajući se da će tako vratiti svoje kupce, Ahmet planira napraviti posebnu ponudu i odlučuje naplaćivati po 1 liru za iznajmljivanje videoigrice nakon što kupac prvo uplati 5 lira unaprijed. Uzimajući tu posljednju situaciju u obzir,

a) nacrtajte graf cijena koje nude oba trgovca na istoj koordinatnoj osi. Molimo, objasnite kako ste ih nacrtali. U(1), R(3)

b) Što mislite, koji trgovac ima bolju ponudu? Objasnite zašto. U(1), U(5), U(6), R(2), R(7)

Prikaz 1. Prvi problemski zadatak u testu iz algebre

Tablica 6

Kako se može vidjeti u tablici 6, 74 učenika imalo je nula bodova na a) dijelu prvog problemskog zadatka, a njih je samo pet imalo svih 12 bodova u tom dijelu. $\mathrm{U}$ b) dijelu zadatka 46 učenika imalo je nula bodova, a dvoje je učenika ostvarilo svih 14 bodova. Od 103 učenika njih 74 nije moglo nacrtati zadani graf za problemsku situaciju, a 46 učenika nije moglo analizirati i procijeniti problem. Uzimajući u obzir važnost sposobnosti učenika da izrade i interpretiraju grafove o stvarnim situacijama i razumiju daljnje pojmove u nastavi matematike, uspjeh učenika bio je zabrinjavajući.

Što se tiče drugoga problemskog zadatka (Prikaz 2), od učenika se očekivalo da pripreme argumente, oblikuju pretpostavke i izrade generalizaciju.

5. Kako biste pronašli nagib pravca na grafu, je li važno koje dvije točke trebate odabrati na tom pravcu? Molim, objasnite. U(3), R(1), R(2), R(6)

Prikaz 2. Drugi problemski zadatak u testu iz algebre

Kako se može vidjeti u tablici 6, 65 učenika imalo je nula bodova na drugom pitanju, a samo ih je 6 ostvarilo svih 26 bodova. To pokazuje da većina učenika nije mogla raspravljati o tome što nagib pravca na grafu znači. 
U trećem problemskom zadatku (Prikaz 3) učenici su trebali analizirati i evaluirati problemsku situaciju, iznijeti pretpostavke i doći do generalizacije, prikazati obrazac s pomoću simbola, grafova, brojeva i tablica, kao i prebacivati se s jedne vrste prikaza na drugu.

5. Znanstvenici su utvrdili da postoji linearna veza između frekvencije glasanja cvrčaka i temperature zraka te su utvrdili pravilo koje predstavlja tu vezu. Kada čujemo cvrčke kako se ujutro glasaju po prvi put, frekvencija je 40 puta u minuti. U podne je 160 puta u minuti. Vrijednosti su prikazane u sljedećoj tablici.
a) Kolika je temperatura zraka kada je frekvencija glasanja $70,80,90,100, \ldots 150$ puta u minuti u tablici ispod? Molimo, izračunajte. U(1), U(3), R(3)
b) Kolika je temperatura zraka kada je frekvencija glasanja 0 ? Molimo, objasnite kako ste došli do rješenja. $\mathrm{U}(3), \mathrm{U}(5), \mathrm{U}(6), \mathrm{R}(3), \mathrm{R}(4)$
c) Kako se temperatura povećava kada se frekvencija glasanja povećava 5 puta u minuti? Molimo, objasnite kako ste došli do rješenja. $\mathrm{U}(1), \mathrm{U}(3), \mathrm{U}(5), \mathrm{U}(6), \mathrm{R}(3), \mathrm{R}(4), \mathrm{R}(6)$
d) Koristeći se danim informacijama, nađite uzorak frekvencije glasanja za bilo koju zadanu temperaturu. Molimo, objasnite što svaki broj u uzorku znači. U(3), U(4), R(1), R(4), R(7)

Prikaz 3. Treći problemski zadatak u testu iz algebre

Kako se može vidjeti u tablici 6, samo dvoje učenika nije moglo odgovoriti na a) dio problemskog zadatka, a ostali su učenici, njih 101, dali točne odgovore. U ovom dijelu pitanja velika većina učenika došla je do odgovora uzimajući u obzir konstantnu razliku između podataka o temperaturi. Iako su kriteriji o a) dijelu zadatka ponovno procijenjeni u dijelovima b) i c) istoga problemskog pitanja, broj učenika koji su ostvarili nula bodova u dijelovima b) i c) povećao se na 45 i na 41, za svaki dio pojedinačno, a broj je učenika koji su ostvarili maksimalan broj bodova na tom dijelu zadatka pao na 54 i 41, za svaki dio pojedinačno. Prema rezultatima koje su učenici ostvarili u ova tri dijela problemskog zadatka, imali su poteškoće u izračunavanju stope promjene između količina prikazanih u tablici. Očito, kako su se učenici usredotočili samo na temperaturu ili samo na frekvenciju glasanja u tom procesu, nisu mogli pronaći vezu između dviju količina koje su varirale ovisno jedna o drugoj. U dijelu d), gdje je broj točnih odgovora bio najmanji, učenici su trebali analizirati problemsku situaciju uspostavljajući veze između prikaza i doći do generalizacije. Od 103 učenika, samo ih je 10 moglo stvoriti točnu generalizaciju o zadanoj vezi.

Uzimajući u obzir činjenicu da je stvaranje generalizacija od ključne važnosti u matematičkim zadatcima, taj rezultat jest zabrinjavajuć. Možda ih je činjenica da su tražili zajednički uzorak usmjeravajući se samo na jednu zadanu količinu u tablici i razmatrajući konstantan porast ili pad, spriječila u tome da dođu do ciljne generalizacije.

U dijelovima a), b) i c) u četvrtom pitanju (Prikaz 4) od učenika se očekivalo da pronađu veze između prikaza među pokazateljima konceptualnog razumijevanja i razmišljanja, da ih interpretiraju i stvore neke pretpostavke. Za razliku od očekivanog ponašanja u prva tri dijela, $u$ dijelu d) učenici su trebali smisliti matematičke argumente, doći do generalizacija s pomoću pretpostavki i ispitati linearnost. 
4. Za sljedeće tri jednadžbe napiši odgovarajuće brojeve u mjesta predviđena za to.

a) $y=5 x+10 \cup(4), R(4)$

\begin{tabular}{|c|l|l|l|l|l|l|}
\hline $\mathbf{x}$ & & & & & & \\
\hline $\mathbf{y}$ & & & & & & \\
\hline
\end{tabular}

b) $y=3 x U(4), R(4)$

\begin{tabular}{|c|l|l|l|l|l|l|}
\hline $\mathbf{x}$ & & & & & & \\
\hline $\mathbf{y}$ & & & & & & \\
\hline
\end{tabular}

c) $y=5 x^{2} U(4), R(4)$

\begin{tabular}{|c|l|l|l|l|l|l|}
\hline $\mathbf{x}$ & & & & & & \\
\hline $\mathbf{y}$ & & & & & & \\
\hline
\end{tabular}

d) Analiziraj tablice i jednadžbe.

iii. Koja je veza linearna, a koja nije? Zašto?

iv. Kako možete odlučiti je li veza linearna ili nije ako pogledate podatke u tablicama

v. jednadžbama? Molimo, detaljno objasnite. $U(2), U(7), R(1), R(2), R(4)$

Prikaz 4. Četvrti problemski zadatak u testu iz algebre

Kako se može vidjeti u tablici 6 , učenici su imali poteškoća pri interpretiranju linearnosti, smišljanju argumenata na temelju pretpostavki i primjeni generalizacija. Sposobnost da se shvate linearne veze i uoče veze između pravca i nagiba ima ključnu ulogu u razvoju matematičkog jezika. Pojam linearne veze je temeljan za pojam funkcije, koja ima važno mjesto u matematici. Zbog česte upotrebe u prirodnim znanostima smatra se i interdisciplinarnim sadržajem. U svjetlu tih činjenica i uspjeha učenika na testu, mogli bismo reći da oni nisu ostvarili očekivane ciljeve.

Kao rezultat, većina je učenika imala nisku razinu konceptualnog razumijevanja i vještina razmišljanja o pojmovima linearna funkcija i nagib pravca. Jedan od razloga mogla bi biti činjenica da su učenici slabo izrazili svoj način razmišljanja u algebarskom testu otvorenoga tipa. Također, još jedan razlog mogla bi biti činjenica da su učenici navikli na testove koji sadrže pitanja višestrukoga izbora i da u Turskoj prevladava nastavna praksa koja učenike priprema za ispite. Stoga smo odlučili provesti kvalitativnu evaluaciju s ciljem detaljnog ispitivanja pokazatelja konceptulanog razumijevanja i razmišljanja kod učenika koje je trebalo odabrati, a koji imaju različite razine postignuća (npr. pet učenika iz grupe koja je imala visoka postignuća i pet učenika iz grupe koja je imala niska postignuća) u spomenutim pojmovima.

\section{Kvalitativni rezultati povezani sa strukturom konceptualnog razumijevanja i razmišljanja o linearnim funkcijama i nagibu pravca Graf pravca}

Prvo pitanje u testu iz algebre zahtijevalo je crtanje grafa koji prikazuje linearnu vezu o problemskoj situaciji i njegovu interpretaciju. Kako se može vidjeti iz rikaza 5, učenici 
su imali različite oblike ponašanja u vezi s temama Razmišljanje i Razumijevanje $i$ prikazivanje.

U sklopu teme Razumijevanje i prikazivanje učenici su pokušali riješiti problemski zadatak s pomoću analize. $U$ tom je procesu četvero učenika $\left(\mathrm{H}_{2}, \mathrm{H}_{3}, \mathrm{H}_{5} \mathrm{i} \mathrm{M}_{2}\right)$ točno riješilo zadatak, no od tih četvero učenika samo je jedan učenik s visokom razinom postignuća $\left(\mathrm{H}_{5}\right)$ u potpunosti riješio zadatak. Drugi učenici, koji nisu mogli točno riješiti problemski zadatak, nisu uspjeli pokazati željeni rezultat, pogotovo u crtanju grafa, jer su nacrtali nepotpune grafove.

U procesu rješavanja problema koristila su se četiri različita oblika prikazivanja, uglavnom grafički i verbalni prikaz. Upotreba grafa nije bila iznenađujuća jer se to $\mathrm{u}$ zadatku ionako tražilo. Međutim, ono što je zabrinjavajuće jest činjenica da većina uečnika nije mogla nacrtati graf na temelju promatranog događaja. Dok su neki učenici crtali nepotpune i netočne grafove, neki graf uopće nisu mogli nacrtati. Nedostatak vještina rješavanja problema i nemogućnost razumijevanja njegove biti mogli bi biti razlog za tu situaciju. Osim grafičkih i verbalnih prikaza jedan se učenik $\left(\mathrm{M}_{2}\right)$ koristio algebarskim prikazom, a dvoje se učenika $\left(\mathrm{H}_{2} \mathrm{i} \mathrm{M}_{2}\right)$ koristilo tabelarnim prikazom.

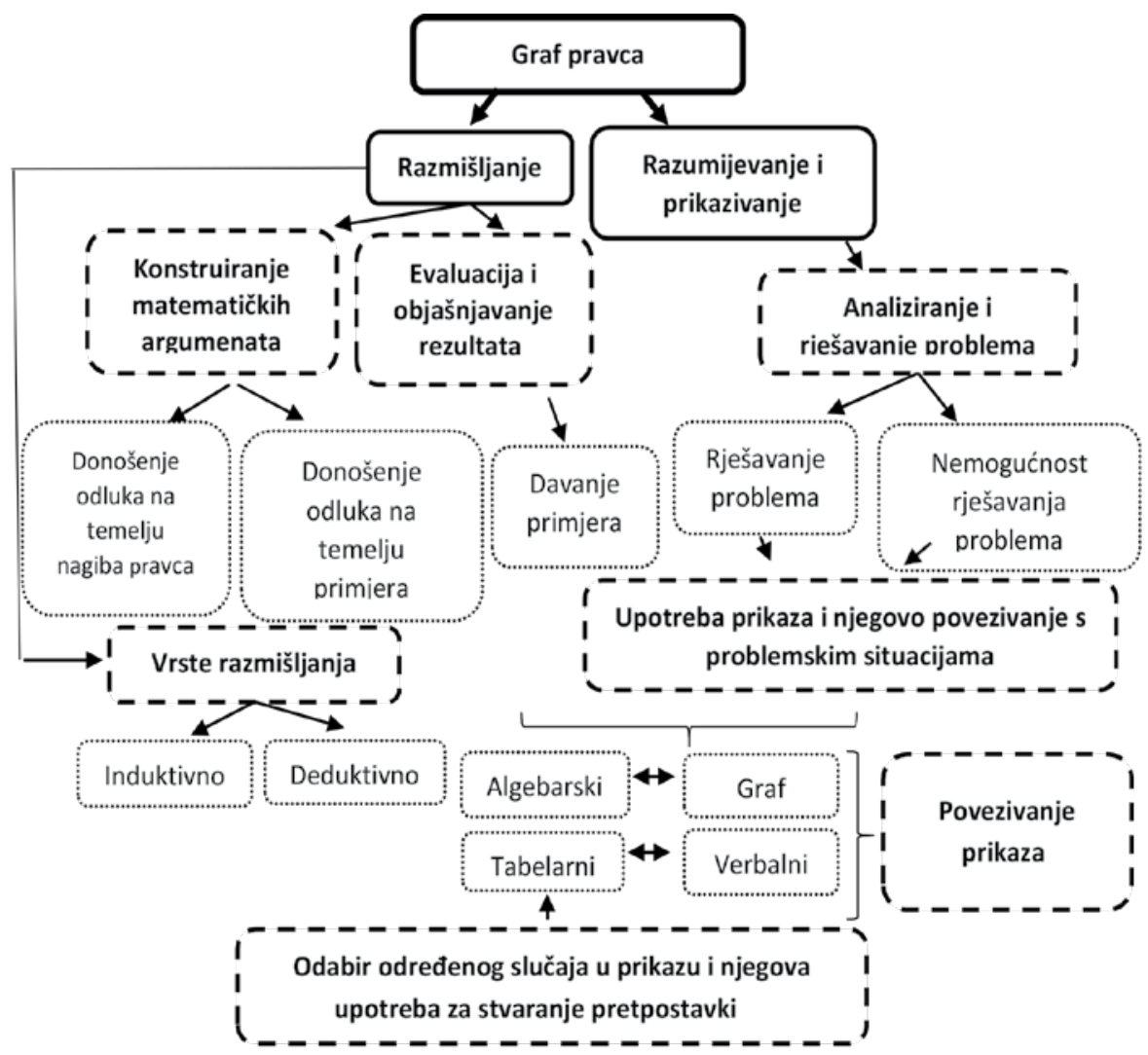

Prikaz 5. Način na koji su učenici razmišljali, razumjeli i prikazali graf pravca u postavljenom problemskom zadatku 
Na prikazu 6 mogu se vidjeti primjeri grafičkih prikaza koje su izradili neki učenici koji su točno riješili problem i oni koji ga nisu mogli riješiti.

Kako se može vidjeti na prikazu 6, usprkos tome što nedostaju neki detalji, možemo reći da je grafički prikaz koji je nacrtao učenik $\mathrm{H}_{5}$ točan. Međutim, mjerne jedinice prikazane na osima nisu bile jednake jer se učenik nije koristio papirom s kvadratićima pri crtanju grafa, niti je imenovao osi. Usprkos tome, učenik $\mathrm{H}_{3}$ nacrtao je zasebne grafičke prikaze za promatranu problemsku situaciju. Drugi su učenici ili nacrtali nepotpune grafove ili nisu mogli uopće nacrtati graf.

Česta pogreška koja se vidjela u grafičkim prikazima bila je tendencija prema crtanju grafa kao pravca $y=a$, tj. grafa pravca koji je paralelan $s$ osi. Njihovo viđenje podatka o 2 lire koje je Mete naplaćivao za svaku iznajmljenu igricu u problemskom zadatku kao „konstantnog broja” možda ih je navelo na takvo razmišljanje. Na primjer, ovo je objašnjenje koje je dao učenik $M_{1}$ :

$\mathrm{M}_{1}$ : ...pita se koji prodavač nudi bolju cijenu. Ovako sam ja nacrtao/la graf. Morate najprije Ahmetu platiti 5 lira, ali onda ćete svaki put plaćati po 1 liru za bilo koji CD koji posudite, bez obzira na to koliko ćete ih posuditi. Zato sam to ovako nacrtao/la.

I: A Mete?

$\mathrm{M}_{1}$ : Mete uvijek naplaćuje 2 lire. Svaki put ćete morati platiti dvije lire, bez obzira na to posuđujete li 1 ili $100 \mathrm{CD}$-a.

Druga pogreška koja je uočena u grafičkom prikazivanju bila je crtanje grafa pravca $\mathrm{y}=\mathrm{mx}$. Učenik $\mathrm{M}_{4}$ je pokušao nacrtati graf pravca $\mathrm{y}=\mathrm{mx}$ umjesto crtanja pravca $\mathrm{y}=\mathrm{mx}+\mathrm{n}$. Ovo je njegovo objašnjenje:

$\mathrm{M}_{4}$ : Ahmet na početku naplaćuje 3 lire za iznajmljivanje videoigrica, no kada dođe Mete, Ahmet daje bolju ponudu i počinje naplaćivati 1 liru za iznajmljivanje videoigrice nakon što mu se unaprijed plati 5 lira. Mete cijelo vrijeme naplaćuje 2 lire.

I: Pa kako si onda nacrtao/la Ahmetov graf?

$\mathrm{M}_{4}$ : On najprije unaprijed dobije 5 lira, no ja to ne mogu nacrtati kao graf.

Prikaz 6.

Kako se može vidjeti na prikazu 5, dva su se učenika $\left(\mathrm{H}_{2} \mathrm{i} \mathrm{M}_{2}\right)$ prebacivala s jedne vrste prikaza na drugu. Učenik $\mathrm{H}_{2}$ prebacio se s tabelarnog prikaza na verbalni, a učenik $\mathrm{M}_{2}$ prebacio se s algebarskog prikaza na grafički prikaz, no u tome baš nije uspio. Prikaz 7 ilustrira primjer te situacije.

\section{Prikaz 7.}

Jedna od podtema unutar glavne teme Razumijevanje i prikazivanje bila je pronaći obrazac u prikazu i koristiti se tim obrascem kako bi se napravile pretpostavke za određeni slučaj. Učenik $\mathrm{H}_{2}$, na primjer, u rješavanju problemskog zadatka najprije se koristio tabelarnim prikazom i protumačio je problem birajući određenu vrijednost u tablici. 
Prikaz 8.

$\mathrm{H}_{2}:$... Nacrtao/la sam tablicu, ali je malo komplicirana. Odmah sam započeo/la s prvom videoigricom na posebnoj ponudi. Ahmet naplaćuje 6 lira po igrici, a Mete 2 lire. Tako za dvije igrice Ahmetu plaćate 7 lira, a Meteu 4 lire. I tako se to nastavlja. Bolje se isplati posuđivati igrice od Ahmeta kada posuđujete više od 5 igrica. Inače, Mete ima bolju ponudu. Razlika je mala kada se radi o više videoigrica. To je zato što Mete naplaćuje uvijek 2 lire.

I: U redu. Što misliš, kakva veza postoji između podataka u ovoj tablici i grafa kojega si nacrtao/la?

$\mathrm{H}_{2}: \mathrm{Pa} . . . \mathrm{hm}$... Nakon nekog vremena Meteu plaćate više nego Ahmetu. Ahmet mi se čini povoljnijim.

Kako se može vidjeti na prikazu 5, pod temom Razmišljanje učenici su izradili niz argumenata putem točnih i netočnih objašnjenja vezanih uz problemsku situaciju. Jedan od učenika sa srednjim akademskim postignućem $\left(\mathrm{M}_{4}\right)$ temeljio je svoje objašnjenje o tome „koji prodavač nudi bolju cijenu” na nagibu pravca, drugi učenici $\left(\mathrm{H}_{1}, \mathrm{H}_{2}, \mathrm{H}_{3}, \mathrm{H}_{4}, \mathrm{H}_{5}, \mathrm{M}_{1}, \mathrm{M}_{2}, \mathrm{M}_{3}, \mathrm{i} \mathrm{M}_{5}\right)$ su svoja objašnjenja temeljili na određenom podatku, tj. na primjeru koji su odabrali. Slijedi objašnjenje učenika $M_{4}$.

$\mathrm{M}_{4:}$ Ahmet je bolji jer ima posebnu ponudu. Ahmet naplaćuje 1 liru za posuđivanje svake videoigrice, nakon što na početku platimo 5 lira, a Mete naplaćuje 2 lire za posuđivanje videoigrice.

I: U redu. Što ćeš mi reći ako te pitam da dokažeš da je Ahmetova ponuda povoljnija?

$\mathrm{M}_{4}: \mathrm{Pa}$, ovako... Kada usporedimo nagib pravca koji prikazuje Ahmetovu ponudu s nagibom pravca koji prikazuje Meteovu ponudu, nagib pravca za Ahmetovu ponudu je 1. Mislim da je graf s manjim nagibom bolji, zar ne? Dakle, onaj s većim nagibom je najskuplji.

Kada je uspoređivao ponude dvaju prodavača, učenik $\mathrm{M}_{4}$ je ignorirao promjenu cijene nakon vrijednosti $\mathrm{x}=6 \mathrm{i}$ ustvrdio da Ahmet uvijek ima bolju ponudu. Taj rezultat mogao bi se objasniti time da je učenik nacrtao graf pravca $\mathrm{y}=\mathrm{mx}$ u grafičkom prikazu problemske situacije. Usprkos tome, od ostalih devetero učenika, učenik $\mathrm{H} 1$ objasnio je svoje rješenje tako što je uspoređivao podatke na odabranom primjeru:

$\mathrm{H}_{1}$ : Mislim da je Ahmetova ponuda privlačnija jer, ako pretpostavimo da posuđujete 100 videoigrica, Ahmetu platite 5 lira na početku i 100 lira za posuđivanje 100 videoigrica. Međutim, Mete naplaćuje 200 lira za posuđivanje 100 videoigrica. Razlika je gotovo $50 \%$.

Slično tome, ostalih četvero učenika koji su dali točne argumente $(\mathrm{H} 2, \mathrm{H} 3, \mathrm{H} 5 \mathrm{i}$ M2) koristili su se primjerima kako bi potvrdili i dodatno objasnili svoje argumente.

Kako se može vidjeti na prikazu 5, u vezi s temama Razmišljanje i razumijevanje i Prikazivanje, učenici su općenito pokazali induktivan pristup tako što su pronašli obrazac u zadanoj problemskoj situaciji na temelju nekoliko posebnih slučajeva. 
Međutim, jedan od tih učenika $\left(\mathrm{M}_{4}\right)$ također je došao do zaključka o boljoj ponudi na temelju nagiba pravaca u dva slučaja analizirana u problemskoj situaciji te je tako demonstrirao deduktivni pristup.

\section{Nagib pravca}

Drugo pitanje bilo je o tome kako su učenici vidjeli nagib pravca na temelju grafičkog prikaza, tabelarnog prikaza i jednadžbe. Kako se može vidjeti na prikazu 9, dali su različita objašnjenja u vezi s temama Razmišljanje i Razumijevanje i prikazivanje.

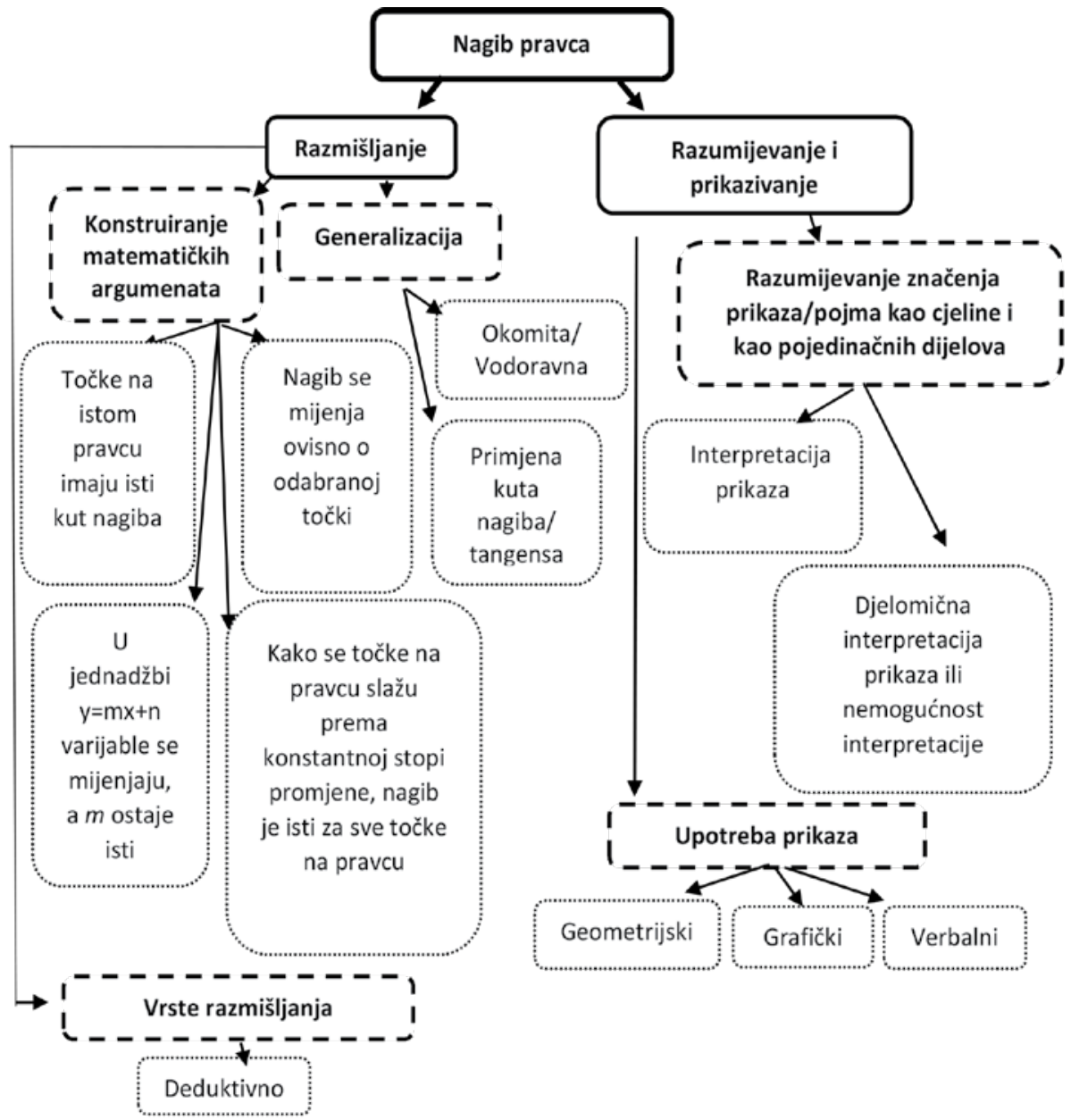

Prikaz 9. Način na koji su učenici razmišljali, razumjeli i prikazali nagib pravca

Dok je troje učenika s visokom razinom postignuća pod temom Razumijevanje i prikazivanje $\left(\mathrm{H}_{1}, \mathrm{H}_{2}\right.$ i $\left.\mathrm{H}_{4}\right)$ točno odgovorilo na pitanja, ostali učenici $\left(\mathrm{H}_{3}, \mathrm{H}_{5}, \mathrm{M}_{1}\right.$, $M_{2}, M_{3}, M_{4} i M_{5}$ ) su mogli interpretirati prikaze djelomično ili ih uopće nisu mogli interpretirati. $\mathrm{U}$ tom procesu učenici su pripremili niz formalnih/neformalnih 
argumenata unutar teme Razmišljanje. Kao ilustracija mogu poslužiti objašnjenja troje učenika s visokom razinom postignuća $\left(\mathrm{H}_{1}, \mathrm{H}_{2} \mathrm{i} \mathrm{H}_{4}\right)$ : „pravac raste ovisno $\mathrm{O}$ konstantnoj stopi promjene, pa je tako nagib isti za sve točke na pravcu”. Međutim, učenik $\mathrm{H}_{2}$ je dodao da ,je kut nagiba pravca jednak za sve točke koje se nalaze na tom pravcu" i prikazao svoj zaključak grafičkim prikazom. Ovo je njegovo detaljno objašnjenje.

I: Što misliš o drugom pitanju?

$\mathrm{H}_{2}$ : Mislim da nije bitno jer se pravac sastoji od točaka. Ako se točke nakupljaju, čine pravac. Sve te točke nalaze se na istom pravcu. Odabrati ovu ili onu točku (pokazuje na pravcu) bilo bi isto. To je zato što jedna s drugom dijele isti kut.

Prikaz 10.

Također, učenik H1 je objasnio: „U jednadžbama $y=m x+n$, varijable ( $x$ i y) se mijenjaju ovisno jedna o drugoj, ali se $m$ ne mijenja”. Ta tri učenika prikazala su nagib s funkcijskim svojstvima, koeficijentima parametara i trigonometrijskim omjerima. Usprkos tome, učenici koji su djelomično interpretirali graf $\left(\mathrm{H}_{3}, \mathrm{H}_{5} \mathrm{i} \mathrm{M}_{4}\right)$ ili ga nisu uspjeli interpretirati $\left(M_{1}, M_{2}, M_{3} i M_{5}\right)$ dali su argument da ,se nagib mijenja ovisno o odabranoj točki na pravcu".

Na primjer, učenik $M_{4}$ je dao ovakvo objašnjenje koristeći se geometrijskim prikazom nagiba pravca na temelju ideje da „udaljenost točaka na pravcu od mjesta gdje pravac siječe os na ishodištu utječe na nagib pravca":

$\mathrm{M}_{4}$ : $\mathrm{Da}$, jer znamo da udaljenosti x i y od ishodišta utječu na odgovor, budući da je nagib pravca okomit/vodoravan.

Učenik $\mathrm{M}_{3}$ je dao drugačije objašnjenje:

$\mathrm{M}_{3}$ : Kako bismo izračunali nagib pravca, moraju se odabrati dvije točke na osima $\mathrm{x}$ i $\mathrm{y}$. Inače ne postoji nagib.

$\mathrm{R}:$ Zašto?

$M_{3}$ : Zato što mora biti 90 stupnjeva. Nema nagiba ako nema 90 stupnjeva. Mora činiti pravokutni trokut kao ovaj (crta ga).

Učenik $\mathrm{M}_{3}$ tvrdio je da je nagib moguć samo uz pravokutni trokut koji se može vidjeti na geometrijskom prikazu u točkama gdje pravac siječe os. Ukratko rečeno, nijedan od tih dvoje učenika nije primijetio konstantnost nagiba pravca u bilo kojoj točki pravca i jednakost konstantne stope između okomite i vodoravne dužine. Također ih je zbunila ideja da „bi se pojavili različiti pravci kako točke na osi variraju i da bi se tako promijenio nagib pravca". Drugi je učenik imao istu ideju kao i učenik $\mathrm{H}_{3}$. On je također tvrdio da će se nagib pravca mijenjati paralelno s promjenom kuta: „Da. Važno je jer se kut nagiba pravca i njegov smjer mijenjaju ovisno o odabranim točkama”. Štoviše, ti su učenici također i ignorirali pravce paralelne s osi. Učenik $\mathrm{M}_{5}$ je mislio da se formula nagiba pravca može izračunati s pomoću određenih točaka na osi i to je ovako objasnio: 
$\mathrm{M}_{5}$ : Kako bi se utvrdio nagib pravca, brojevi koji su označeni na osima x i y uzeti su u obzir jer se tako nalazi formula za nagib pravca.

Kako se može vidjeti na prikazu 9, učenici su stvarali generalizacije o nagibu pravca koristeći se geometrijskim prikazima $\left(\mathrm{H}_{1}, \mathrm{H}_{2}, \mathrm{H}_{3}, \mathrm{H}_{4}, \mathrm{H}_{5}, \mathrm{M}_{1}, \mathrm{M}_{2}, \mathrm{M}_{3}, \mathrm{M}_{4} \mathrm{i}\right.$ $\left.\mathrm{M}_{5}\right)$ i trigonometrijskim prikazima $\left(\mathrm{H}_{2}, \mathrm{H}_{3}\right.$ i $\left.\mathrm{M}_{3}\right)$. Drugim riječima, koristili su se deduktivnim pristupom tako što su donosili zaključke na temelju premisa o nagibu pravca tijekom cijelog procesa, koje su uključivale komponentu okomito/vodoravno ili tangens pravokutnog trokuta i kut.

\section{Funkcijska veza}

Treći je problem ispitivao sposobnost učenika da ispitaju vezu između dviju količina - jedna je bila zavisna, a druga nezavisna količina - u linearnoj funkciji i da analiziraju stopu promjene. Prikaz 11 pokazuje različite izjave učenika pod temama Razmišljanje i Razumijevanje i prikazivanje.

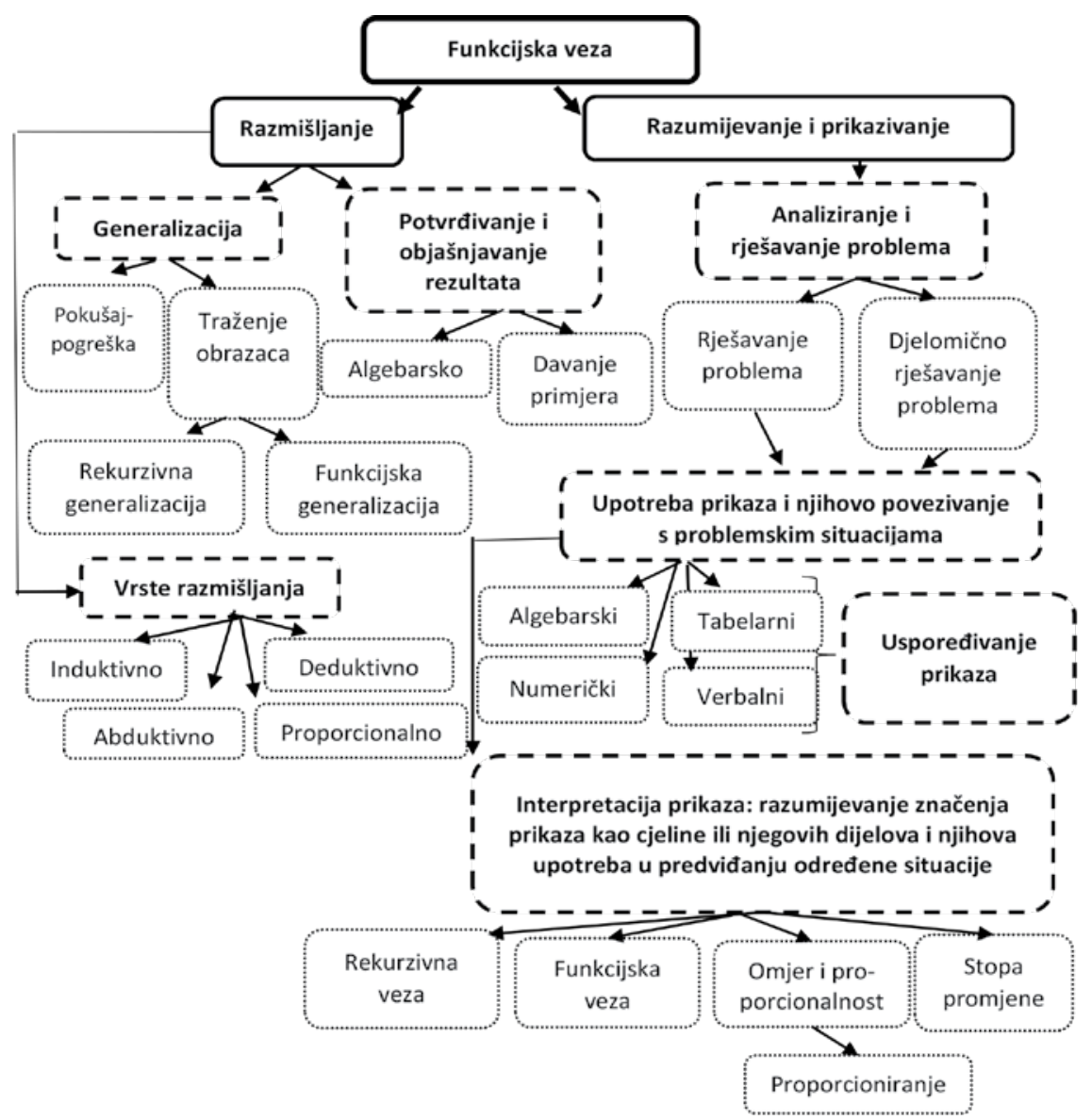

Prikaz 11. Način na koji su učenici razmišljali, razumjeli i prikazali funkcijsku vezu u problemskom zadatku 
Pod temom Razumijevanje i prikazivanje učenici su pokušali analizirati i riješiti problem. Samo je dvoje učenika s visokom i srednjom razinom postignuća $\left(\mathrm{H}_{3} \mathrm{i}\right.$ $\mathrm{M}_{1}$ ) moglo riješiti problem, a ostali učenici nisu mogli riješiti određene dijelove problemskog zadatka.

U prvom dijelu problemskog zadatka svi su učenici izračunali ciljne temperature izračunavanjem konstantnog porasta u obrascu prikazanome na tablici i verbalno objasnili kako će se temperatura nastaviti dalje. Primjer je bio odgovor koji je dao učenik $\mathrm{H}_{5}$.

\section{Prikaz 12}

Kada su rješavali ostale dijelove zadatka, učenici su se, osim verbalnog prikaza, koristili još trima različitim vrstama prikaza. Od tih je učenika dvoje s visokom razinom postignuća i jedan učenik sa srednjom razinom postignuća $\left(\mathrm{H}_{1}, \mathrm{H}_{3}, \mathrm{i} \mathrm{M}_{1}\right)$ upotrebljavalo algebarski prikaz, dvoje učenika $\left(\mathrm{M}_{1} \mathrm{i}_{5}\right)$ je upotrebljavalo numerički, a dvoje učenika $\left(\mathrm{M}_{2} \mathrm{i}_{5}\right)$ tabelarni prikaz. Slika 13 pokazuje primjere vrsta prikaza koje su ti učenici upotrebljavali:

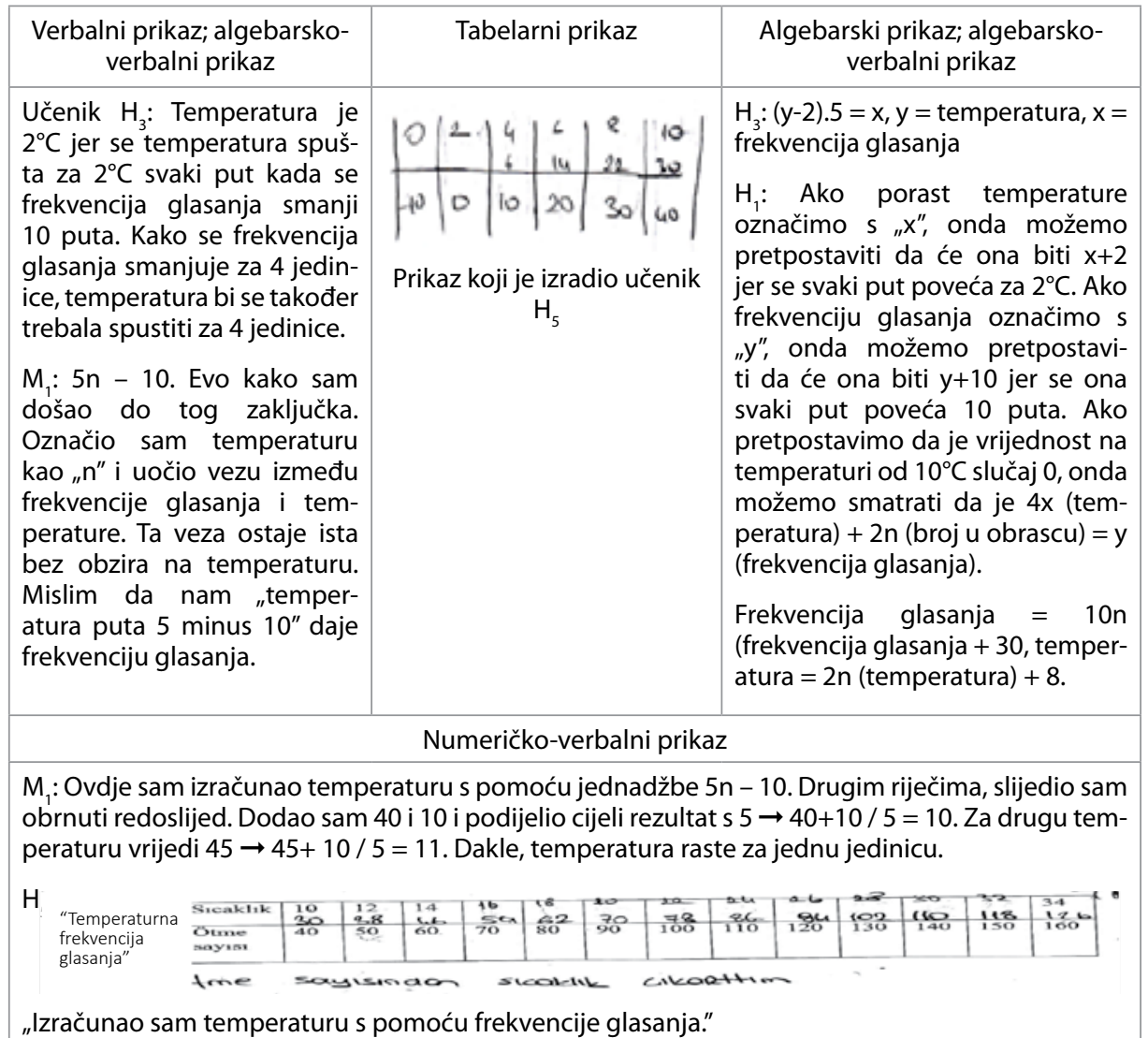

Prikaz 13. Višestruki prikazi koje su izradili učenici za 3. problemski zadatak 
Tijekom analize i rješavanja problemskog zadatka učenici su otkrili rekurzivne i funkcijske veze i također se koristili omjerom i proporcionalnošću.

Što se tiče pitanja u kojem se tražila temperatura kada je frekvencija glasanja 0 , sedam je učenika $\left(\mathrm{H}_{1}, \mathrm{H}_{2}, \mathrm{H}_{5}, \mathrm{M}_{2}, \mathrm{M}_{3} \mathrm{M}_{4}\right.$ i $\left.\mathrm{M}_{5}\right)$ izračunalo temperaturu koristeći se rekurzivnom vezom a da u obzir nisu uzeli vezu između temperature i frekvencije pjevanja, a na temelju konstantnog smanjivanja termina u obrascu. Primjer je odgovor učenika $\mathrm{M}_{2}$ :

Prikaz 14

$\mathrm{M}_{2}$ : Zbog toga što je minimalna temperatura za glasanje cvrčaka $4^{\circ} \mathrm{C}$ i počinje nakon $2^{\circ} \mathrm{C}$, cvrčci se nikada ne glasaju na temperaturi od $0^{\circ} \mathrm{C}$ ili $2^{\circ} \mathrm{C}$.

Usprkos tome, učenik $\mathrm{H}_{3}$ je izračunao vrijednost temperature izračunavši veličinu promjene $\mathrm{u}$ temperaturi kod konstantnog porasta ili pada $\mathrm{u}$ frekvenciji glasanja $\mathrm{u}$ tablici. Ovo je njegovo objašnjenje:

b) Koja je temperatura kada je frekvencija glasanja 0 ? Molim, objasni kako si došao do rješenja.

$\mathrm{H}_{3}$ : Temperatura je $2^{\circ} \mathrm{C}$ zato što se temperatura spušta za $2^{\circ} \mathrm{C}$ svaki put kada se frekvencija glasanja smanji za 10. Kako se frekvencija glasanja smanjuje za četiri jedinice, temperatura bi se također trebala smanjiti za četiri jedinice.

Iako učenik nije izračunao stopu promjene, činjenica da je bio svjestan toga da promjena postoji, konceptualno je jako važna. Kako se može vidjeti ispod, učenik sa srednjom razinom postignuća, koji je došao do rješenja funkcijskim pristupom $\left(M_{1}\right)$, izračunao je vrijednost temperature koristeći se jednadžbom koju je najprije oblikovao na temelju funkcijske veze između frekvencije glasanja i temperature.

b) Kolika je temperatura kada je frekvencija glasanja 0? Molim, objasni kako si došao do rješenja.

$M_{1}$ : Zato što je jednadžba $5 n-10 \ldots$ a temperaturu smo označili kao „n”. Ona tako daje frekvenciju glasanja i možemo slijediti obrnut poredak. Mislim, ako dodamo 10 i podijelimo ukupni dobiveni rezultat $s 5$, dobit ćemo temperaturu. $0+10=1010 / 5=2$. Temperatura je 2 Celzijeva stupnja.

Slično tome, $\mathrm{u}$ sljedećem dijelu problemskog zadatka u kojem je trebalo izračunati kako će se temperatura povećati kada se frekvencija glasanja poveća pet puta u minuti, osam učenika $\left(\mathrm{H}_{1}, \mathrm{H}_{2}, \mathrm{H}_{3}, \mathrm{H}_{5}, \mathrm{M}_{2}, \mathrm{M}_{3}, \mathrm{M}_{4} \mathrm{i} \mathrm{M}_{5}\right)$ je točno procijenilo promjenu temperature na osnovi toga da bi smanjenje u frekvenciji glasanja bilo uzrokovano proporcionalnim smanjenjem temperature. Ovo je jedan od odgovora:

c) Kako se temperatura povećava kada se frekvencija glasanja poveća pet puta u minuti? Molim, objasni kako si došao do rješenja.

$M_{3}$ : U ovom slučaju temperatura raste za 1 stupanj svaki put jer se dvaki put povećavala za dva stupnja. Ovdje se frekvencija glasanja smanjila za pola. Tako će i porast temperature biti upola manji. 
Učenik $\mathrm{H}_{1}$ je izračunao vrijednost temperature s pomoću proporcionalnosti na ovaj način:

c) Kako se temperatura povećava kada se frekvencija glasanja poveća pet puta u minuti? Molim, objasni kako si došao do rješenja.

$\mathrm{H}_{1}$ : Kada se frekvencija glasanja poveća za 5 , temperatura se poveća za $1^{\circ} \mathrm{C}$. To sam izračunao s pomoću omjera. Kada se frekvencija glasanja poveća za 10, temperatura se poveća za $2^{\circ} \mathrm{C}$. $\mathrm{U}$ tom se slučaju poveća za 5 svaki put kada temperatura poraste za $1^{\circ} \mathrm{C}$.

Objašnjenje učenika $M_{1}$, koji je izračunao vrijednost temperature s pomoću jednadžbe koju je sam postavio, slijedi u daljnjem tekstu. Algebarsko razmišljanje uključuje izvođenje matematičkih procesa i njihov obrnuti postupak. Drugim riječima, zahtijeva sposobnost kretanja od početne točke prema dalje, ili zahtijeva obrnuti postupak razmišljanja - krenuti od kraja prema početku. Učenik je imao bolje konceptualno razumijevanje tog problemskog zadatka i na temelju njegovih postupaka u oba dijela zadatka možemo reći da je imao visoku razinu vještine algebarskog razmišljanja.

c) Kako se temperatura povećava kada se frekvencija glasanja poveća pet puta u minuti? Molim, objasni kako si došao do rješenja.

$\mathrm{M}_{1}$ : Ovdje sam izračunao temperature prema jednadžbi $5 n-10$. Drugim riječima, išao sam obrnutim redoslijedom. Dodao sam $40 \mathrm{i} 10 \mathrm{i}$ podijelio ukupan rezultat s $5 \rightarrow 40+10 / 5=10$. Za drugu temperaturu formula je bila: $45 \rightarrow 45+10 / 5=$ 11. Dakle, temperatura raste za jednu jedinicu.

Jedna od podtema u temi Razumijevanje i prikazivanje bila je prebacivanje s jedne vrste prikaza na drugi. Kako se može vidjeti na Slici 13 ili u citatima učeničkih odgovora, tri učenika $\left(\mathrm{H}_{1}, \mathrm{M}_{1}\right.$ i $\left.\mathrm{M}_{2}\right)$ mogla su se koristiti kombinacijama prikaza: algebarsko-verbalnog, numeričko-verbalnog i tabelarno-verbalnog. Međutim, samo je jedan od tih učenika $\left(M_{1}\right)$ mogao smisleno međusobno povezati te prikaze.

Kako se može vidjeti na prikazu 11, pod temom Razmišljanje, neki su učenici stvorili generalizacije o problemskoj situaciji i pokušali ih potvrditi i obrazložiti. Kada je o generalizacijama riječ, u posljednjem dijelu problemskog zadatka učenici su trebali postaviti jednadžbu na temelju dviju količina i objasniti što svaki termin u toj jednadžbi znači. Nažalost, samo je dvoje učenika $\left(\mathrm{H}_{3}\right.$ i $\left.\mathrm{M}_{1}\right)$ uspjelo postaviti točnu jednadžbu. Usprkos tome, jedan od tih dvoje učenika, učenik $\mathrm{H}_{3}$ (s visokom razinom postignuća), uspio je doći do rješenja s pomoću metode pokušaja i pogreške i dao sljedeće objašnjenje:

I: Koje je općenito pravilo obrasca?

$\mathrm{H}_{3}$ : $(\mathrm{y}-2) .5=\mathrm{x}$; ovdje se y odnosi na temperaturu, a x se odnosi na frekvenciju glasanja.

I: U redu. Kako si došao do toga?

$\mathrm{H}_{3}$ : Isprobavajući brojeve. Isprobao sam brojeve iz tablice. 
Učenik $\mathrm{H}_{3}$ procijenio je točnost svoje jednadžbe tako što ju je testirao $\mathrm{s}$ određenom vrijednosti temperature. Ovako je to objasnio:

I: Dakle, primjenjuju li se ta pravila na sve?

$\mathrm{M}_{2}$ : Provjerit ćemo. Ako je temperatura 10 stupnjeva, onda vrijedi (10-2).5 = 8.5= 40 i to je točan rezultat. Frekvencija glasanja je 40.

I: A u sljedećem koraku?

$\mathrm{M}_{2}$ : Kada je temperatura 12 stupnjeva, onda vrijedi (12-2) $5=50$. Ovo je opet točno, pa to mora biti pravilo.

Učenik $M_{1}$ postavio je jednadžbu na temelju funkcijske veze između frekvencije glasanja i temperature. Taj učenik potvrdio je točnost svoje jednadžbe deduktivnim pristupom na ovaj način:

$\mathrm{M}_{1}$ : Postoji veza između temperature i frekvencije glasanja. Kako bismo pronašli tu vezu, na primjer, trebali bismo pronaći istu jednadžbu između 10 i 40 i 34 i 160. U tim je jednadžbama formula „5n-10”. Ako sa „n” označimo temperaturu i koristimo se jednadžbom „5n-10", možemo doći do toga da je frekvencija glasanja... 5n-10. Ovako sam to pronašao. Označio sam temperaturu kao „n” i pronašao vezu između frekvencije glasanja i temperature. Ta veza ostaje ista bez obzira na temperaturu. Mislim da nam „pet puta temperatura minus deset” daje frekvenciju glasanja.

Svi učenici, osim učenika $\mathrm{M} 1$, uglavnom su primijenili induktivan pristup rješavanju problema. Pogotovo u dijelovima b) i c) problemskog zadatka, neki učenici $\left(\mathrm{H}_{1}, \mathrm{H}_{2}\right.$, $\mathrm{H}_{3}, \mathrm{H}_{5}, \mathrm{M}_{2}, \mathrm{M}_{3}, \mathrm{M}_{4} \mathrm{i} \mathrm{M}_{5}$ ) su se koristili proporcionalnim razmišljanjem tako što su usporedili dvije količine, navodeći kako promjena bilo koje od njih utječe na drugu. $\mathrm{Na}$ primjer, učenik $\mathrm{H}_{2}$ ovako je objasnio proporcionalno razmišljanje:

c) Kako se temperatura povećava kada se frekvencija glasanja poveća pet puta u minuti? Molim, objasni kako si došao do rješenja.

H2: Ako se frekvencija glasanja poveća za 10 , temperatura će se povećati za 2, a ako se frekvencija glasanja poveća za 5 , temperatura će se povećati za 1 . To je pravi omjer.

Učenik $H_{1}$ postavio je jednadžbu tako što je najprije promatrao određeni slučaj, odnosno, tako što je uzeo u obzir stalan porast temperature i frekvenciju glasanja primjenom abduktivnog pristupa (abduktivno razmišljanje moguće je kada se stvori zaključak koji vodi prema stvaranju tvrdnje na temelju promatranja određene situacije). Ovo je primjer takve situacije:

$\mathrm{H}^{1}$ : Ako temperaturu označimo $\mathrm{s}$ „x”, možemo reći da je „x+2” jer se svaki put temperatura poveća za $2^{\circ} \mathrm{C}$. Ako frekvenciju glasanja označimo kao „y”, svaki će put porasti 10 puta i vrijedit će $y+10 \ldots$ Ako ga prihvatimo kao nultu vrijednost na $10^{\circ} \mathrm{C}$, bit će $4 x+2 n=y$. Frekvencija glasanja je $10 n+30$. Temperatura je $2 n+8$. 


\section{Linearnost}

Četvrtim problemskim zadatkom ispitalo se kako se shvaća linearnost s pomoću tablica, jednadžbi ili grafičkih prikaza. Prikaz 15 daje objašnjenja učenika u vezi s temama Razmišljanje i Razumijevanje i prikazivanje.

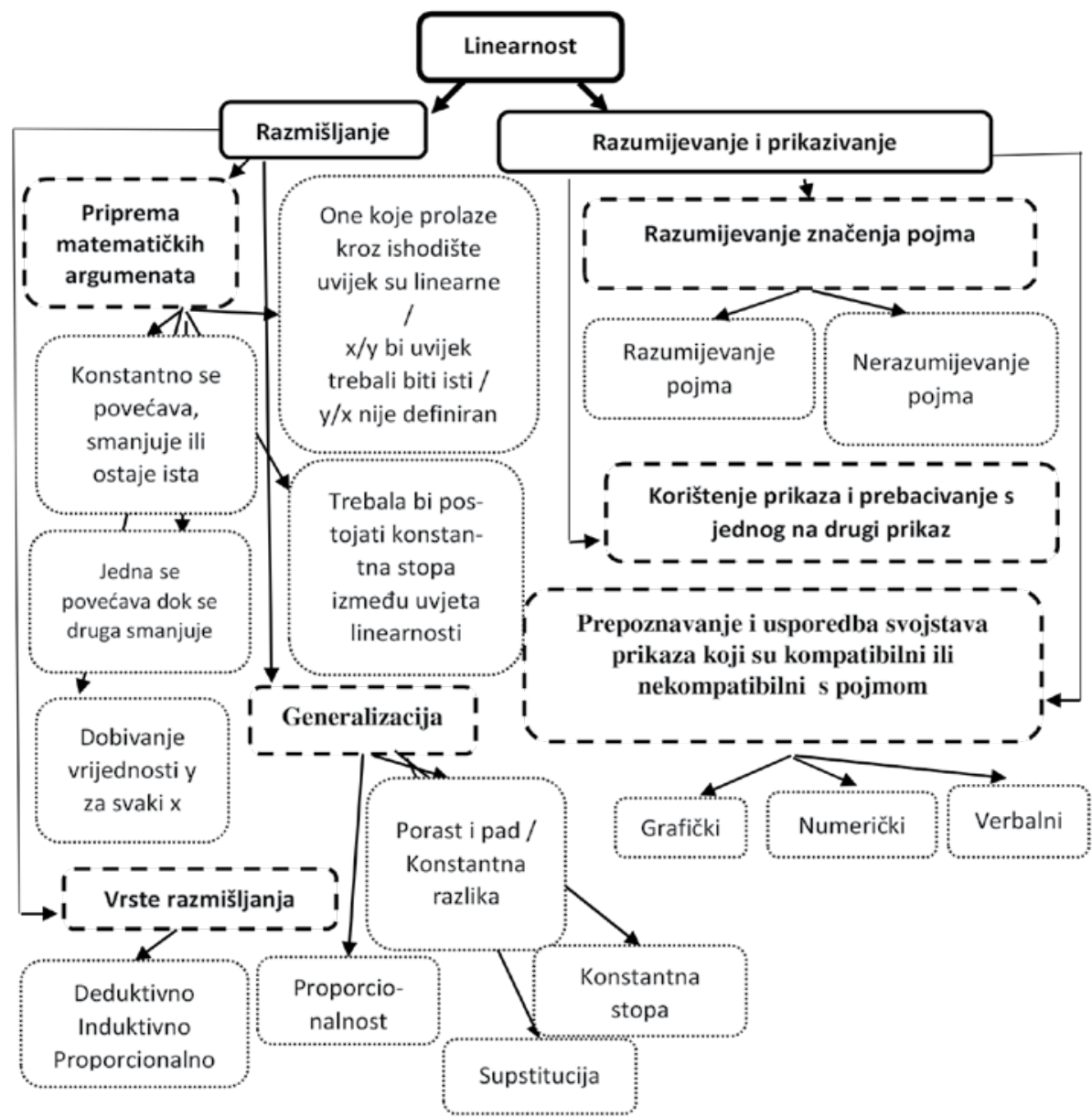

Prikaz 15. Način na koji učenici razmišljaju o linearnosti i prikazuju je

Kako se može vidjeti na rikazu 15, svi su učenici točno popunili tablice o linearnim i nelinearnim jednadžbama u vezi s temom Razumijevanje i prikazivanje. Neki su se učenici, međutim, koristili samo pozitivnim cijelim brojevima umjesto vrijednosti $\mathrm{x} u$ zadanim jednadžbama, a drugi su u te brojeve uključili i nulu. Odgovor jednog učenika može poslužiti kao primjer (prikaz 16).

Prikaz 16

Četvrti problem ispitivao je pojam linearnosti. $\mathrm{U}$ dijelu d) ovoga zadatka četvero učenika s visokom razinom postignuća $\left(\mathrm{H}_{1}, \mathrm{H}_{2}, \mathrm{H}_{3} \mathrm{i} \mathrm{H}_{5}\right)$ i dvoje učenika sa srednjom 
razinom postignuća $\left(\mathrm{M}_{3} \mathrm{i} \mathrm{M}_{5}\right)$ protumačilo je linearnu vezu tako što su ispitali svoje jednadžbe i tabelarne prikaze. TI učenici izrazili su linearnu vezu sa stalnim porastom ili padom vrijednosti x i y, a samo je jedan učenik $\left(\mathrm{H}_{1}\right)$ uz to spomenuo i konstantu. Ti su učenici uzeli u obzir konstantnu razliku u y vrijednostima, a neki su učenici $\left(\mathrm{H}_{1}, \mathrm{H}_{3}\right.$ $\mathrm{i}_{3}$ ) do neke mjere naglasili i stopu promjene. Navodimo neke primjere razmišljanja učenika o pojmu linearnosti:

d) Koja je veza linearna, a koja nije? Zašto?

$\mathrm{H}_{1}$ : Linearno je ono što možemo opisati kao stalan napredak. U linearnim vezama napredak konstantno raste ili ostaje nepromjenjiv, ili se trajno smanjuje. Ponekad postoji i omjer. Na primjer, graf koji pokazuje utjecaj temperature na frekvenciju glasanja je linearan i pokazuje trajni rast.

$\mathrm{H}_{3}$ : Ja sam mislio da su dijelovi a) i b) linearni.

I: Zašto si to mislio?

$\mathrm{H}_{3}$ : Ovdje $\mathrm{x}$ raste paralelno $\mathrm{s} \mathrm{y}$. $\mathrm{U}$ jednadžbi $\mathrm{y}=3 \mathrm{x}, \mathrm{x}$ se povećava paralelno $\mathrm{s}$.

I: Ali vrijednost $\mathrm{x}$ raste kako i vrijednost $\mathrm{y}$ raste $\mathrm{u}$ dijelu $\mathrm{c})$ ?

$\mathrm{H}_{3}: \mathrm{Da}$, ali nisam mogao tu pronaći nikakvo posebno pravilo.

I: Kako si onda uspio pronaći ostala?

$\mathrm{H}_{3}$ : U dijelu a) y se povećava za pet, a u dijelu b) povećava se za tri.

I: A u dijelu c)?

$\mathrm{H}_{3}$ : Tu nisam mogao pronaći konstantnu stopu, pa sam mislio da to nije linearna veza.

$\cdots$

I: Zašto misliš da se $\mathrm{y}=5 \mathrm{x}^{2}$ nije povećao za određenu stopu?

$\mathrm{H}_{3:}$ Zato što je dio c) kvadratna jednadžba. Mislim, ima kvadrat. U tom slučaju stvari se mijenjaju. Vrijednosti ne rastu konstantnom stopom.

d) Koja je veza linearna, a koja nije? Zašto?

$\mathrm{M}_{3}$ : a i b su linearne zato što se povećavaju i padaju istim omjerom. Međutim, to nije slučaj kod c.

I: Što misliš kada kažeš da se povećavaju i padaju na isti način?

$\mathrm{M}_{3}$ : Povećava se za pet u dijelu a), a za tri u dijelu b).Zato sam rekao da se povećava i smanjuje na isti način.

Učenik H5 je usporedio sličnosti i razlike u prikazima tako šte se prebacivao s algebarskog prikaza na tabelarni, a s tabelarnog na grafički, numerički i verbalni prikaz. Taj je učenik također izrazio linearnost ravnom crtom na grafu.

d) Koja je veza linearna, a koja nije? Zašto?

Prikaz 17

I: Kako si, u zadanim jednadžbama, zaključio koje imaju linearnu vezu?

$\mathrm{H}_{5}$ : Najprije sam nacrtao njihove grafove (pokazuje na graf koji je nacrtao). Kada sam dodao vrijednosti 1, 2 i 3 za x, y je konstantno postajao 15, 20 i 25, za svaku 
vrijednost $\mathrm{x}$ zasebno. Pomislio sam da tu mora postojati linearna veza jer se svaki put vrijednost povećavala za pet, a graf je imao jednoličan rast.

I: U redu. Jesu li i ostale također imale linearnu vezu?

$\mathrm{H}_{5}$ : Dio b) ima, ali dio c) nema.

I: Zašto je to tako?

$\mathrm{H}_{5}$ : Zato što kada dodam vrijednosti, y postaje 5, 20 i 45 . Tu ne postoji nikakav obrazac. Da je nacrtam kao graf, ne bi bio linearan.

I: Dakle, kako si, gledajući u tablicu, odlučio postoji li linearna veza ili ne postoji?

$\mathrm{H}_{1}$ : Ako je nelinearna, neće imati konstantnu stopu, a graf će biti u obliku cik-cak linije. Ali ako je linearna, graf će ići gore ili dolje konstantnom stopom.

Kako se može vidjeti na prikazu 15, pod temom Razmišljanje, učenici koji su dobro razumjeli pojam linearnosti, imali su argumente poput ,stalno se povećava, smanjuje ili ostaje isti” $i$,trebala bi postojati konstantna stopa između uvjeta za linearnost". Također, na temelju tih argumenata, učenici su stvorili generalizacije o linearnosti koristeći se izjavama poput „konstantna razlika u uvjetima”, „povećanje ili smanjenje s obzirom na obrasce ili na uvjete nepromjenjiva stanja”, ili ,konstantna stopa u uvjetima za linearnost".

Neki od učenika koji su razumjeli ili nisu razumjeli pojam $\left(\mathrm{H}_{3}, \mathrm{M}_{1}\right.$ i $\left.\mathrm{M}_{5}\right)$ dali su odgovore generalizirajući pojam linearnih veza u kombinaciji s pojmom ispravnih proporcionalnosti. Učenik $\mathrm{M}_{5} \mathrm{je}$, na primjer, dao sljedeće objašnjenje:

I: Što misliš, što proporcionalnost označava?

$\mathrm{M}_{5}$ : Linearnost je kada se nešto povećava dok se nešto drugo također povećava.

I: Primjenjuje li se to samo na porast?

$\mathrm{M}_{5}$ : Ne. Isti je slučaj i kod smanjivanja.

Kako se može vidjeti na prikazu 15 , jedan učenik s visokom razinom postignuća $\left(\mathrm{H}_{4}\right)$ i troje učenika sa srednjom razinom postignuća $\left(\mathrm{M}_{1}, \mathrm{M}_{2}\right.$ i $\left.\mathrm{M}_{4}\right)$ dali su netočne odgovore o pojmu linearnosti. Usmjeravajući se na proporcionalnost u linearnim jednadžbama, ti su učenici ili naveli da su samo jednadžbe u obliku $y=m x$ linearne ili su povezali način dobivanja vrijednosti y s pomoću vrijednosti x s linearnošću. U svjetlu toga stvorili su argumente poput „oni koji prolaze kroz ishodište su uvijek linearni, $\mathrm{x} / \mathrm{y}$ bi uvijek trebali biti jednaki, ili y/x nije definiran” ili „potrebno je dobiti y s pomoću svake vrijednosti x". Ti učenici očito su netočno generalizirali linearnost $\mathrm{u}$ jednadžbama $\mathrm{y}=m \mathrm{x}$ ili dobivanje vrijednosti $\mathrm{y}$ s pomoću svake vrijednosti $\mathrm{x}$. Slijede neki primjeri koji ilustriraju tu situaciju:

I: Što bi ti odgovorio da te pitam je li $y=3 x+10$ linearan ili nije?

$\mathrm{M}_{4}$ : Linearan je ako prolazi kroz ishodište, a nije linearan ako ne prolazi. Ovaj nije linearan jer ne prolazi kroz ishodište.

Učenik $M_{1}$ je dao sličan odgovor:

I: Što bi ti odgovorio na pitanje jesu li jednadžbe $y=2 x 2$ ili $y=3 x+10$ linearne? 
$\mathrm{M}_{1}$ : Mislim da su jednadžbe $\mathrm{y}=2 \times 2$ linearne.

A. Zašto to misliš?

$\mathrm{M}_{1}$ : Ona druga ima konstantan broj. Ima broj 10. Zato nije linearna.

Slijedi odgovor koji je dao učenik $\mathrm{H}_{4}$ :

I: Što misliš, koja od jednadžbi zadanih u problemskom zadatku ima linearnu vezu?

$\mathrm{H}_{4}$ : Samo dio b).

I: Zašto?

$\mathrm{H}_{4}$ : Zato što bi se uvijek trebao dobiti isti broj kada podijelimo vrijednosti $\mathrm{x} s$ vrijednostima y. Takav je slučaj samo u b) dijelu zadatka.

$\mathrm{Na} \mathrm{kraju,} \mathrm{usprkos} \mathrm{tome} \mathrm{što} \mathrm{je} \mathrm{imao} \mathrm{sasvim} \mathrm{drugačiji} \mathrm{pristup} \mathrm{od} \mathrm{pristupa} \mathrm{učenika} \mathrm{H}_{4}$, učenik $\mathrm{M}_{2}$ je rekao da je samo dio b) linearan i komentirao to ovako:

I: Što misliš, koja od jednadžbi zadanih u problemskom zadatku sadrži linearnu vezu?

$\mathrm{M}_{2}$ : Samo $\mathrm{u}$ dijelu $\left.\mathrm{b}\right) . \mathrm{y}=5 \mathrm{x}+10$ nije linearan jer je $\mathrm{y} / \mathrm{x}$ nedefiniran, 15 podijeljeno sa 1 je 15 (piše po zadatku), 20 podijeljeno s 2 je 10, 25 podijeljeno sa 3 je oko 8 cijelih nešto. Mislim, ne postoji točna stopa.

$\mathrm{Na}$ kraju, učenik $\mathrm{M}_{1}$ je objasnio kako on/ona shvaća pojam linearnosti: „linearni su jer uvijek dobijem vrijednost y bez obzira na to što odredim da je vrijednost $\mathrm{x}$. Na primjer, ako uzmemo da je $y=20 u y=5 x^{2}$, dobijem $x=2$ iz $4=x^{2}$." Također smo primijetili da su se učenici koristili induktivnom, deduktivnom i proporcionalnom vrstom razmišljanja tijekom cijelog procesa.

\section{Rasprava, zaključak i preporuke}

Naši kvantitativni rezultati pokazali su da više od polovine učenika (54,36 \%) ima nisku razinu postignuća u vezi s pojmovima linearna funkcija i nagib pravca. Zadatci otvorenoga tipa u testu iz algebre, činjenica da su učenici navikli na pitanja višestrukoga izbora u testovima i tendencija da se nastavna praksa prilagodi načinu provedbe ispita $u$ školama u Turskoj mogli bi biti neki od razloga za to. Istraživanja su pokazala da se nastava matematike više usmjerava na operativno znanje učenika nego na konceptualno znanje učenika o algebarskim pojmovima (Baki i Kartal, 2004). Zapravo, kada su se svaki problemski zadatak i praktično pitanje u testu iz algebre ocjenjivali zasebno s obzirom na konceptualno znanje, rezultati su išli u prilog toj situaciji, što upućuje na činjenicu da učenici nemaju primjerenu razinu konceptualnog razumijevanja pojmova linearna funkcija i nagib pravca. Jedan od pokazatelja te situacije jest taj što većina učenika nije uspjela točno odgovoriti na problemske i praktične zadatke. Štoviše, kvalitativni rezultati koji omogućuju detaljniju analizu pokazatelja konceptualnoga razumijevanja i razmišljanja o linearnim funkcijama i nagibu pravca idu u prilog kvantitativnim rezultatima. Međutim, kako bi se izbjegla preopširna generalizacija, trebali bismo imati na umu da su kvalitativni rezultati u istraživanju dobiveni na uzorku od 10 učenika - pet učenika s visokom razinom postignuća i pet učenika sa srednjom razinom postignuća. 
Kvalitativni su rezultati pokazali da je malo učenika moglo točno riješiti problemske i praktične zadatke, iako su imali visoku razinu postignuća. Ti su učenici očito imali adekvatnu razinu konceptualnog razumijevanja pri analizi i rješavanju problemskih situacija iz svakodnevnog života, pri razumijevanju značenja prikaza kao cjeline i kao pojedinačnih dijelova, pri upotrebi višestrukih vrsta prikaza i njihovu povezivanju $s$ problemskim zadatcima, kao i pri prebacivanju s jedne vrste prikaza na drugu. Uz to, uzimajući u obzir vodeću ulogu vještina razmišljanja u ostvarivanju konceptualnog razumijevanja, učenici koji su bili dobri u konceptualnom razumijevanju također su imali i dobru razinu vještine razmišljanja, što se manifestiralo u argumentiranju, stvaranju generalizacija, procjeni i objašnjavanju rezultata. Tako je taj rezultat u skladu $s$ rezultatima drugih istraživanja koja su pokazala da su razumijevanje i razmišljanje međusobno povezani i da se isprepleću (Ball i Bass, 2003; Cheng, 2010).

Analiza konceptualnog znanja učenika i njihovo znanje o različitim vrstama prikaza pojma nagib pravca, stopa promjene i linearne veze u kontekstu konceptualnog razumijevanja pokazala je da je većina učenika u našem istraživanju imala poteškoća u određivanju nagiba pravca i da su mislili da će se nagib mijenjati paralelno s točkama na pravcu. Slično tome, Postelnicu (2011) je došao do rezultata da su učenici najviše poteškoća imali u određivanju i interpretaciji nagiba pravca na grafu.

Također smo primijetili da su, općenito govoreći, učenici definirali nagib koristeći se izrazima poput: „dijeljenje vodoravne dužine okomitom dužinom”, „kut nagiba” ili „tangens”. Međutim, kako su istraživanja (Clement, 1985; Duncan i Chick, 2013; Stump, 2001b) pokazala, neki učenici nisu uspjeli objasniti svoje definicije i nisu mogli dati opisna i logična objašnjenja. Ta situacija ukazuje na to da neki učenici percipiraju pojam nagiba u operativnom, a ne u konceptualnom aspektu. Drugi rezultat koji ide u prilog toj tvrdnji jest način na koji je jedan učenik demonstrirao varijable okomite i horizontalne duljine nagiba na pravokutnom trokutu, bez razmišljanja. Taj rezultat je u skladu s rezultatima Birgina (2006). Ukratko, kako pokazuju dobiveni rezultati (Barr, 1981; Hattikudur, Prather, Asquith, Alibali, Knuth i Nathan, 2012; Lobato i Siebert, 2002; Lobato i Thanheiser, 2002; Planinic, Milin-Sipus, Kati, Susac i Ivanjek, 2012; Stump, 2001b; Teuscher i Reys, 2010), neki učenici u našem istraživanju nisu bili svjesni konstantnosti nagiba na bilo kojoj točki pravca, kao ni jednakosti konstantne stope između okomite i vertikalne duljine pravca. Na krivi odgovor ih je navela ideja da „kako se točke na osi mijenjaju, javljaju se različiti pravci i stoga će se također mijenjati i nagib pravaca". Svejedno, primijetili smo da su oni učenici koji su bili svjesni veze između nagiba pravca i stope promjene mogli pronaći potrebnu potvrdu za svoje mišljenje te da su to mogli objasniti višestrukim vrstama prikaza u tom procesu.

Ako pogledamo naše rezultate s obzirom na linearne veze, može se primijetiti da su neki učenici smatrali da su linearni pravci samo oni čija je formula $y=m x$ i koji prolaze kroz ishodište, a da oni čija je formula $\mathrm{y}=\mathrm{mx}+\mathrm{n}$ nisu linearni. Barr (1981) i Moschkovich (1996) dobili su slične rezultate. Uz učenike koji su mogli objasniti linearnost ovisno o „konstantnom porastu ili padu” između varijabli, neki drugi 
su promatrali linearne veze samo u smislu „proporcionalnosti” i mislili da će biti dovoljno imati vrijednost koja se povećava/smanjuje paralelno s drugom vrijednošću koja se povećava/smanjuje bez obzira na konstantnu stopu. Neki naši učenici također su pokušali objasniti linearnost ovisno o konstantnoj vrijednosti koju su dobili stavljajući varijable poput $\mathrm{y} / \mathrm{x}$ ili $\mathrm{x} / \mathrm{y}$ u proporcionalni odnos, ili ovisno o promjenjivim vrijednostima, pa su, drugim riječima, uzeli u obzir proporcionalne situacije $\mathrm{u}$ linearnim jednadžbama $(y=m x)$, a zanemarili neproporcionalne situacije $(y=m x+n)$. Slično tome, Birgin (2006) je došao do rezultata koji su pokazali da učenici nisu mogli odrediti vezu između nagiba pravca i varijabli x i y. Razmatrajući važnost uloge pojma stope u nagibu pravca, učenici su vjerojatno imali poteškoća u razumijevanju tog pojma, pa su bili jako zbunjeni nagibom, stopom promjene i linearnim vezama. Ti su rezultati također potvrđeni činjenicom da su neki učenici izrazili pojam linearnosti kao „dobivanje vrijednosti y za svaku vrijednost $x$ " $u$ jednadžbi pravca i tvrdnjom da je kvadratna jednadžba tipa „y=2 $2 x^{2 ”}$ linearna. Slično tome, Stump (2001) i Teuscher i Reys (2010) su došli do spoznaje da sudionici u njihovu istraživanju nemaju dovoljno dobro razumijevanje stope promjene i da imaju problema s tim pojmom. Ukratko, ovi rezultati upućuju na to da naši učenici ne razumiju značenje simbola u jednadžbama pravca, nego su naučili napamet formule a da nisu detaljno razumjeli te pojmove. Postojanje sličnih rezultata u stručnoj literaturi (Anderson, 2008; Barr, 1981; Birgin, 2012; Moschkovich, 1996; Stump, 1999; Teuscher i Reys, 2010), nažalost, upućuje na stalne poteškoće s tim pojmovima.

Kada pogledamo rezultate znanja učenika o različitim vrstama prikaza pojmova linearna funkcija i nagib pravca u kontekstu konceptualnog razumijevanja, možemo reći da učenici preferiraju verbalne, algebarske, grafičke, tabelarne, numeričke i geometrijske prikaze, no omiljen im je verbalni prikaz. Međutim, kada je ispitivao u kojoj su se mjeri učenici mogli koristiti simbolima i grafičkim prikazima, Knuth (2000) je izjavio da se učenici najviše koriste algebarskim prikazima i da je to možda uvjetovano kurikulom. Iako su se neki od učenika koji su sudjelovali u našem istraživanju koristili višestrukim prikazima, njima se nisu točno koristili i teško im je bilo prebacivati se $s$ jednoga na drugi i objašnjavati ih. Svi učenici osim jednoga imali su poteškoće pogotovo u upotrebi grafičkih i algebarskih prikaza te su, kako je bio slučaj i u nekim drugim istraživanjima (Birgin, 2006; Demirci i Uyanık, 2009; Knuth, 2000; Önür, 2008; Postelnicu, 2011; Reiken, 2008; Teuscher i Reys, 2010), crtali grafove prema formuli $y=a$ i $y=m x$ i započinjali su graf od ishodišta. Također, neki algebarski izrazi bili su postavljeni metodom pokušaja i pogreške i algebarskim prikazima, što je pokušao jako malen broj učenika. Kada s gledišta vještina razmišljanja analiziramo rezultate o načinu na koji su učenici stvarali svoje argumente, generalizacije i objašnjavali rezultate i preferirane vrste razmišljanja, možemo reći da oni učenici koji nisu bili dobri u konceptualnom razumijevanju također nisu bili dobri ni u izradi odgovarajućih argumenata o pojmovima stopa promjene i linearne veze, ni u objašnjavanju svojim argumenata. Štoviše, naši su učenici općenito primjenjivali 
nekoliko vrsta razmišljanja, kao što je rekurzivno (između varijabli), funkcionalno, induktivno (putem odnosa proporcionalnosti), deduktivno, proporcionalno i abduktivno, ali je jako malo učenika imalo točne procjene.

Kao zaključak, nameće se da konceptualno razumijevanje ne znači pamćenje formula koje omogućavaju izvođenje praktičnih operacija ili točno rješavanje problemskih zadataka primjenom formula. Međutim, većina učenika u našem istraživanju računala je na površno znanje o pojmovima linearna funkcija i nagib, uglavnom su se držali formule za nagib i jednadžbe pravca te nisu imali odgovarajuće vještine razmišljanja. Uzimajući u obzir važnost znanja o prikazima za konceptualno razumijevanje, naši učenici trebaju više raditi na primjeni višestrukih prikaza i prebacivanju s jedne vrste prikaza na drugi, a trebali bi više raditi i na interpretaciji tih prikaza. $U$ svjetlu toga, za razvoj i konceptualnog znanja i vještina razmišljanja možemo reći da bi se proces učenja i poučavanja u školama trebao usredotočiti na problemske situacije iz svakodnevnog života, a ne na mnoge vrste pitanja od kojih se testovi sastoje. K tomu, trebali bismo stvoriti takvo okruženje za učenje i poučavanje koje bi učenike poticalo da se usredotoče na „zašto" $i$ „kako" u raspravama, da se koriste raznolikim prikazima, da postavljaju pitanja, interpretiraju različite probleme, stvaraju logičke zaključke i provode analize i sinteze.

Ovo istraživanje može se proširiti tako da uključi učenike u različitim razredima i različita predmetna područja. Također, buduća bi istraživanja trebala ispitati u kojoj su mjeri nastavnici matematike koji predaju matematiku učenicima koji su sudjelovali u ovom istraživanju svjesni njihovih pogrešaka ili krivih predodžbi te kakvu bi nastavnu strategiju trebali usvojiti kako bi eliminirali prepoznate pogreške i krive predodžbe. 


\section{DODATAK}

\section{KRITERIJI I REZULTATI EVALUACIJE TESTA IZ ALGEBRE}

\begin{tabular}{|c|c|c|}
\hline $\begin{array}{l}\text { Problemski } \\
\text { zadatak }\end{array}$ & Kriteriji & Bodovi \\
\hline & - Nije dan odgovor ili je odgovor netočan. & 0 \\
\hline & - Imenovanje koordinatnih osi na grafu za prvoga prodavača. & 1 \\
\hline & $\begin{array}{l}\text { - Imenovanje koordinatnih osi na grafu za prvoga prodavača i } \\
\text { određivanje početne točke. }\end{array}$ & 4 \\
\hline & $\begin{array}{l}\text { - Imenovanje koordinatnih osi na grafu za prvoga prodavača i } \\
\text { određivanje početne točke, a zatim označavanje uređenih parova. }\end{array}$ & 5 \\
\hline & $\begin{array}{l}\text { - Imenovanje koordinatnih osi na grafu za prvoga prodavača } \\
\text { i određivanje početne točke, a zatim označavanje parova te } \\
\text { dovršavanje grafa spajanjem uređenih parova. }\end{array}$ & 6 \\
\hline \multirow[t]{6}{*}{$1 \mathrm{a}$} & - Imenovanje koordinatnih osi na grafu za drugoga prodavača. & 1 \\
\hline & $\begin{array}{l}\text { - Imenovanje koordinatnih osi na grafu za drugoga prodavača i } \\
\text { određivanje početne točke. }\end{array}$ & 4 \\
\hline & $\begin{array}{l}\text { - Imenovanje koordinatnih osi na grafu za drugoga prodavača i } \\
\text { određivanje početne točke, a zatim označavanje uređenih parova. }\end{array}$ & 5 \\
\hline & $\begin{array}{l}\text { - Imenovanje koordinatnih osi na grafu za drugoga prodavača } \\
\text { i određivanje početne točke, a zatim označavanje parova te } \\
\text { dovršavanje grafa spajanjem uređenih parova. }\end{array}$ & 6 \\
\hline & - Točan crtež dvaju grafova. & 12 \\
\hline & - Ukupan broj bodova & 12 \\
\hline \multirow[t]{4}{*}{$\begin{array}{c}\text { Problemski } \\
\text { zadatak }\end{array}$} & Kriteriji & Bodovi \\
\hline & - Nije dan odgovor ili je odgovor netočan. & 0 \\
\hline & $\begin{array}{l}\text { - Nemogućnost određivanja zajedničke točke dvaju prodavača, a } \\
\text { izrečeno je mišljenje da je druga ponuda povoljnija od prve. }\end{array}$ & 2 \\
\hline & $\begin{array}{l}\text { - Nemogućnost određivanja zajedničke točke za dva prodavača, a } \\
\text { izrečeno je mišljenje da dobit ovisi o broju CD-a. }\end{array}$ & 4 \\
\hline \multirow[t]{4}{*}{$1 b$} & $\begin{array}{l}\text { - Nije određena zajednička točka za dva prodavača te je interpreti- } \\
\text { ran samo jedan primjer. }\end{array}$ & 6 \\
\hline & - Određena je samo zajednička točka. & 6 \\
\hline & $\begin{array}{l}\text { - Određivanje zajedničke točke kroz graf o igricama/cijeni ili tablici o } \\
\text { dva prodavača; zatim slijedi interpretacija. }\end{array}$ & 14 \\
\hline & Ukupan broj bodova: & 14 \\
\hline
\end{tabular}




\begin{tabular}{|c|c|c|}
\hline $\begin{array}{l}\text { Problemski } \\
\text { zadatak }\end{array}$ & Kriteriji & Bodovi \\
\hline \multirow{7}{*}{2} & - Nije dan odgovor ili je odgovor netočan. & 0 \\
\hline & - Određen je samo nagib pravca. & 5 \\
\hline & - Interpretacija se temelji na nagibu pravca. & 5 \\
\hline & $\begin{array}{l}\text { - Interpretacija se temelji na tome čine li odabrane točke pravokutni } \\
\text { trokut. }\end{array}$ & 8 \\
\hline & $\begin{array}{l}\text { - 1. rješenje: Interpretacija se temelji na činjenici da dvije odabrane } \\
\text { točke moraju biti na istom pravcu. }\end{array}$ & 26 \\
\hline & $\begin{array}{l}\text { - 2. rješenje: Crtanje grafa jednadžbe " } y=a x+b \text { ", a nakon toga } \\
\text { određivanje nagiba dviju točaka na tom grafu. }\end{array}$ & 26 \\
\hline & Ukupan broj bodova: & 26 \\
\hline \multirow[t]{3}{*}{$\begin{array}{l}\text { Problemski } \\
\text { zadatak }\end{array}$} & Kriteriji & Bodovi \\
\hline & - Nije dan odgovor ili je odgovor netočan. & 0 \\
\hline & - 1. rješenje: Popunjavanje tablice ritmičkim brojanjem & 4 \\
\hline \multirow[t]{2}{*}{$3 a$} & $\begin{array}{l}\text { - 2. rješenje: Popunjavanje tablice primjenom formule za aritmetički } \\
\text { niz }\end{array}$ & 4 \\
\hline & Ukupan broj bodova: & 4 \\
\hline $\begin{array}{l}\text { Problemski } \\
\text { zadatak }\end{array}$ & Kriteriji & Bodovi \\
\hline \multirow{4}{*}{$3 b$} & - Nije dan odgovor ili je odgovor netočan. & 0 \\
\hline & - Dobiven je netočan rezultat zbog pogreške u računanju. & 2 \\
\hline & - Popunjavanje tablice ritmičkim odbrojavanjem. & 4 \\
\hline & Ukupan broj bodova: & 4 \\
\hline $\begin{array}{l}\text { Problemski } \\
\text { zadatak }\end{array}$ & Kriteriji & Bodovi \\
\hline \multirow{4}{*}{$3 c$} & - Nije dan odgovor ili je odgovor netočan. & 0 \\
\hline & - Verbalno izražavanje o proporcionalnosti . & 3 \\
\hline & - Dobivanje točnog rezultata s pomoću proporcionalnosti. & 6 \\
\hline & Ukupan broj bodova: & 6 \\
\hline $\begin{array}{l}\text { Problemski } \\
\text { zadatak }\end{array}$ & Kriteriji & Bodovi \\
\hline \multirow{3}{*}{$3 d$} & - Nije dan odgovor ili je odgovor netočan. & 0 \\
\hline & - Pronalaženje formule. & 10 \\
\hline & Ukupan broj bodova: & 10 \\
\hline
\end{tabular}


Tanışh and Bike Kalkan: Linear Functions and Slope: How Do Students Understand These Concepts and ...

\begin{tabular}{|c|c|c|}
\hline $\begin{array}{c}\text { Problemski } \\
\text { zadatak }\end{array}$ & Kriteriji & Bodovi \\
\hline \multirow{4}{*}{$4 a / b / c$} & - Nije dan odgovor ili je odgovor netočan. & 0 \\
\hline & - Netočno uvrštavanje varijabli. & 2 \\
\hline & - Dobivanje vrijednosti y s pomoću vrijednosti $x$. & 4 \\
\hline & Ukupan broj bodova: & 4 \\
\hline $\begin{array}{l}\text { Problemski } \\
\text { zadatak }\end{array}$ & Kriteriji & Bodovi \\
\hline \multirow{4}{*}{$4 d_{i}$} & - Nije dan odgovor ili je odgovor netočan. & 0 \\
\hline & - 1. rješenje: Interpretacija linearnosti na temelju konstantne razlike. & 6 \\
\hline & - 2. rješenje: Interpretacija linearnosti crtanjem grafa ili tablice. & 6 \\
\hline & Ukupan broj bodova: & 6 \\
\hline $\begin{array}{l}\text { Problemski } \\
\text { zadatak }\end{array}$ & Kriteriji & Bodovi \\
\hline \multirow{5}{*}{$4 d_{i i}$} & - Nije dan odgovor ili je odgovor netočan. & 0 \\
\hline & - Interpretacija linearnosti na temelju podataka u tablici. & 3 \\
\hline & - Interpretacija linearnosti na temelju jednadžbe. & 3 \\
\hline & - Interpretacija linearnosti na temelju i tablice i jednadžbe. & 6 \\
\hline & Ukupan broj bodova: & 6 \\
\hline
\end{tabular}

